UNIVERSIDADE DE SÃO PAULO

FACULDADE DE CIÊNCIAS FARMACÊUTICAS

PROGRAMA DE PÓS-GRADUAÇÃO EM CIÊNCIA DOS ALIMENTOS ÁREA DE NUTRIÇÃO EXPERIMENTAL

\title{
O FARNESOL INIBE A PROLIFERAÇÃO CELULAR E INDUZ A APOPTOSE EM RATOS WISTAR SUBMETIDOS À HEPATECTOMIA PARCIAL
}

CARLOS EDUARDO ANDRADE CHAGAS

Dissertação apresentada para obtenção do título de Mestre em Ciência dos Alimentos

Orientador: Prof. Assoc. Fernando Salvador Moreno

\author{
São Paulo \\ 2006 \\ 18.47 .3
}




\section{DEDALUS - Acervo - CQ

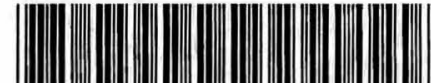 \\ 30100011695}

Ficha Catalográfica

Elaborada pela Divisào de Biblioteca e

Documentaçào do Conjunto das Químicas da USP.

\footnotetext{
Chagas, Carlos Eduardo Andrade

C433r O farnesol inibe a proliferaça celutar e induz a apoptose em ratos Wistar submetidos à hepatectomia parcial ! Carlos Eduardo Andrade Chagas. -- Sào Paulo, 2005. $93 p$.

Dissertaça (mestrado) Faculdade de (iencias Farmaccuticas da Universidade de Sào Paulo. Departamento de Alimentose Nutriçào Experimental.

Orientador: Moreno. Fernando Salvador

1. Nutriçáo experimental : Ciencia dos alimentos ?. Ciclo: celular: Fisiologia 3. Apoptose : Patologia 1. T. II. Moreno, Fernando Salvador, orientador.
}

641.1 (DI) 


\section{Carlos Eduardo Andrade Chagas}

\section{O FARNESOL INIBE A PROLIFERAÇÃO CELULAR E INDUZ A APOPTOSE EM RATOS WISTAR SUBMETIDOS À HEPATECTOMIA PARCIAL}

Comissão Julgadora

da

Dissertação para obtenção do grau de Mestre

\section{Prof. Dr. Fernando Salvador Moreno orientador/presidente}

\section{$1^{\circ}$. examinador}

$2^{\circ}$. examinador

São Paulo, de 
A minha querida mãe Vera, e a família Yoshime.

CHAGAS C.E. A. 


\section{AGRADECIMENTOS}

Primeiramente a Deus, criador de tudo, e que me proporcionou a vida;

Aos professores Cezar Henrique de Azevedo, Sandra Maria Lima Ribeiro e Luciana Passos Toledo, pela força durante a minha graduação, por sempre me motivar em busca do conhecimento científico e me incentivarem a seguir a carreira docente;

Ao Prof. Assoc. Fernando Salvador Moreno, um dos ícones da pesquisa em nutrição no Brasil, pela oportunidade de trabalhar junto a ti, receptividade, amizade e principalmente, pelos ensinamentos e oportunidades ao longo desses anos;

A toda a minha família: Manuel, Felipe e principalmente minha mãe, Vera Lúcia, pelo incentivo em busca dos meus sonhos, ajuda financeira e por sempre ter acreditado em mim;

A minha namorada Luciana Yoshime, pela companhia, amor, incentivo e paciência comigo durante todos esses anos;

A minha afilhada Ana e aos grandes amigos Rafael Gossn, Rafael Passos, Felipe, Gustavo, Renata, Cristiano e André pela convivência paciência, incentivo. Sem vocês, a vida definitivamente não seria a mesma!!!

A familia Yoshime: Tokinobu, Nilcea, Izaltina e Alex, por terem me acolhido como um filho em sua casa;

Ao Prof. Dr. João Roberto Nascimento e ao Dr. Thomas Ong pelas observações e comentários durante o exame de qualificação; 
Ao Dr. Rogério Pietro Mazzantini e Renato Heidor, queridos amigos e companheiros, por nunca ter me negado auxílio e pela paciência para me ensinar técnicas de laboratório. Se hoje sou capaz de realizá-las, devo tudo isso a vocês!!!

Aos demais amigos do laboratório: Aline, Mariana, Bianca, Joice, Mônica, Alessandra, Renata e Bruna;

A Profa. Dra. Maria Aparecida Lopes da Costa pela ajuda durante o sacrifício dos animais;

A Lourdes, pelo carinho e ajuda na organização do laboratório;

A Profa. Tit. Maria Lúcia Zaidan Dagli, Patrícia Matsuzaki e aos demais membros do Laboratório de Oncologia Experimental do Departamento de Patologia da Faculdade de Medicina Veterinária e Zootecnia da USP pela ajuda com as análises utilizando o PCNA;

Aos colegas demais colegas de pós-graduação: Luciana, Rogério, Jose Donato, Adair, João Paulo, Aderuza, Gracieli, Cristiane, Maritza, Simone, Gabriela, Fernanda, Alexandre e Malu;

A professora Bernadete Franco, pela ajuda durante o meu ingresso neste programa de pós-graduação;

A todos os professores que contribuíram com a minha formação, em especial ao Prof. Emérito Éder Quintão;

A todos os funcionários do COSEAS-USP e do restaurante do conjunto das químicas da USP, por me proporcionar alimentação durante esses anos;

A todos os funcionários do Departamento de Alimentos e Nutrição Experimental da Faculdade de Ciências Farmacêuticas da USP; 
A Elaine e Jorge, funcionários da secretaria de pós-graduação da Faculdade de Ciências Farmacêuticas da USP;

Aos todos os funcionários do biotério do Conjunto das Químicas, em especial à Flavia e Renata;

Finalmente, ao CNPq e a FAPESP pela bolsa de estudos e auxílio financeiro para a realização desse trabalho. 


\section{LISTA DE FIGURAS}

FIGURA 1: Via de transdução do sinal mediada por TNF- $\alpha$

FIGURA 2: Esquema de ativação de NFKB 24

FIGURA 3: Via resumida do mevalonato em plantas e mamíferos 33

FIGURA 4: Estrutura de alguns isoprenóides 34

FIGURA 5: Representação esquemática do protocolo experimental para 43

avaliação das atividades do farnesol na proliferação celular, apoptose e na expressão hepática dos genes para p65, ciclina D1 e HMG-CoA redutase, em ratos Wistar tratados durante duas semanas consecutivas com o isoprenóide e submetidos à hepatectomia parcial.

FIGURA 6: Evolução do peso corpóreo de ratos Wistar tratados com óleo

de milho ou farnesol durante 2 semanas consecutivas

FIGURA 7: Consumo diário de ração de ratos Wistar tratados com

óleo de milho (OM) ou farnesol (FR) durante 2 semanas consecutivas

FIGURA 8: Índice de proliferação celular hepática de ratos Wistar tratados com óleo de milho ou farnesol e submetidos ao protocolo experimental

FIGURA 9: Índice apóptótico hepático de ratos Wistar tratados com óleo 56 de milho ou farnesol e submetidos ao protocolo experimental FIGURA 10: Digitalização de corte histológico de fígado de rato Wistar tratado com farnesol durante 2 semanas consecutivas e sacrificado 30 minutos após a hepatectomia parcial.

FIGURA 11: Expressão hepática de p65 de ratos Wistar tratados com OM ou FR e submetidos ao protocolo experimental.

FIGURA 12: Expressão hepática de ciclina D1 de ratos Wistar tratados com óleo de milho ou farnesol e submetidos ao protocolo experimental.

FIGURA 13: Avaliação da expressão hepática do gene para HMG-CoA redutase em animais tratados com óleo de milho ou farnesol e submetidos à hepatectomia parcial 


\section{LISTA DE TABELAS}

TABELA 1 - Alguns modelos experimentais disponiveis para estudo da regeneração hepática in vivo

TABELA 2 - Pesos corpóreos iniciais e finais, bem como consumo médio de ração de ratos Wistar tratados com óleo de milho ou farnesol durante 2 semanas consecutivas e submetidos à hepatectomia parcial TABELA 3 - Pesos absoluto e relativo do fígado no momento do 50 sacrifício dos animais tratados com óelo de milho ou farnesol durante duas semanas consecutivas e submetidos à HP. 


\section{ÍNDICE}

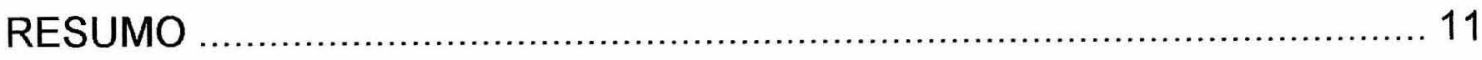

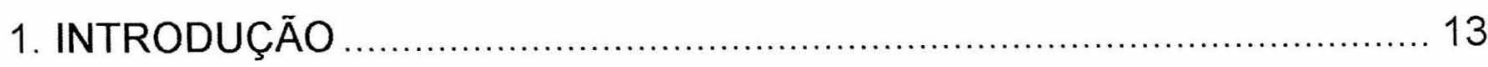

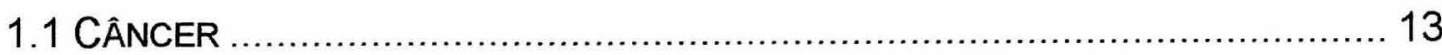

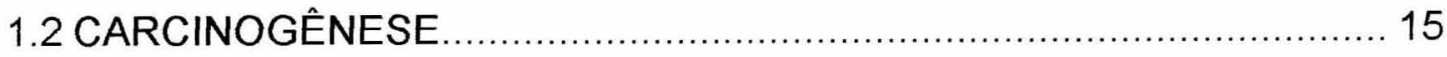

1.3 REGENERAÇÃO HEPÁTICA, CICLO CELULAR E APOPTOSE ............17

1.4 A RELAÇÃO ALIMENTAÇÃO, NUTRIÇÃO E CÂNCER ..................................... 28

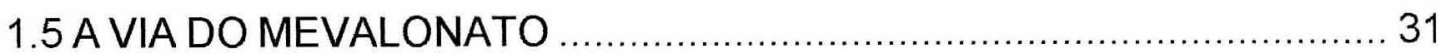

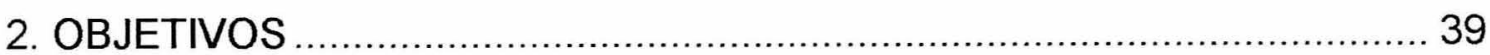

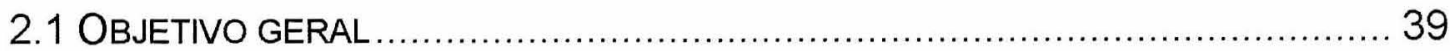

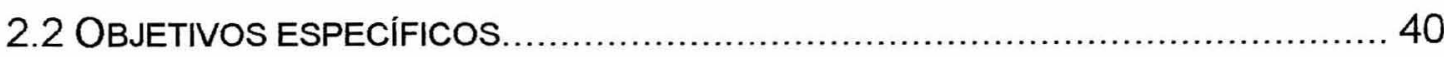

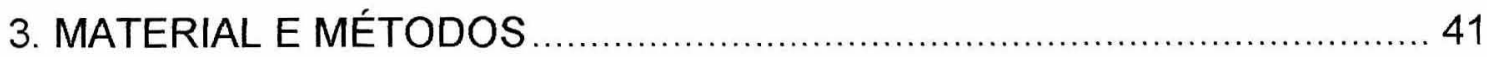

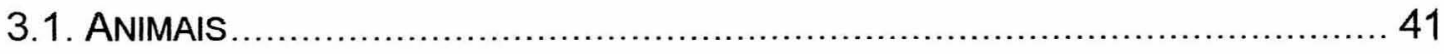

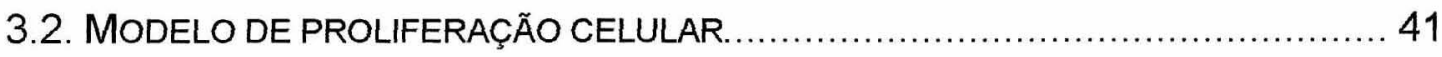

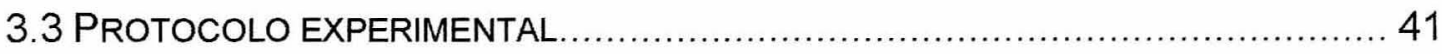

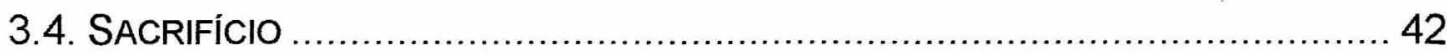

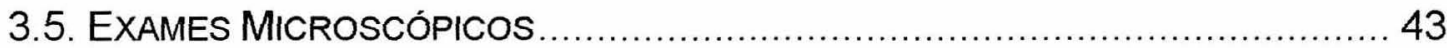

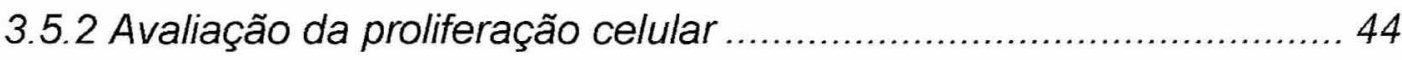

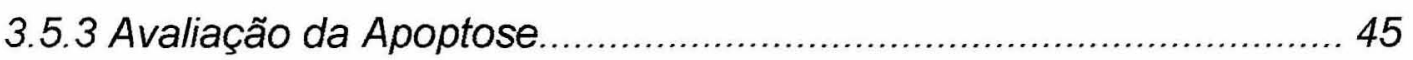

3.6 AVALIAÇÃO DA EXPRESSÃO HEPÁTICA DE P65 E CICLINA D1 ...........................45

3.6.1 Obtenção do extrato protéico total hepático .................................. 45

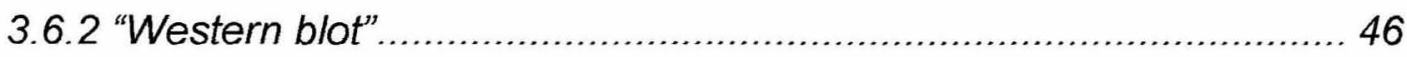

3.7 AVALIAÇÃO DA EXPRESSÃO DO GENE QUE CODIFICA PARA A ENZIMA HMG-COA

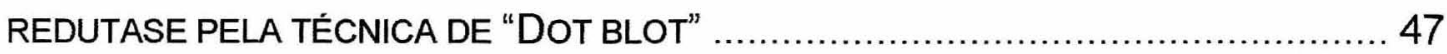

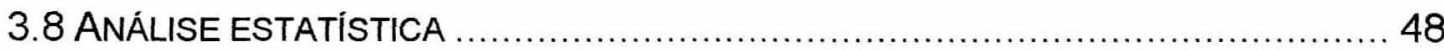

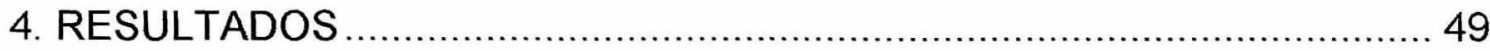

4.1 Pesos Corpóreos InICIAL E Final, bem Como Peso do Fígado por OCASIÃO dO SACRIFICIO E CONSUMO DE RAÇÃo dOS ANIMAIS SUBMETIDOS AO

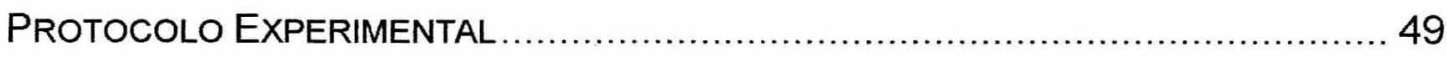

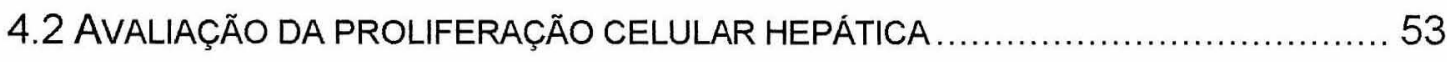


4.3 AVALIAÇÃO dA APOPTOSE HEPÁTICA ............................................ 55

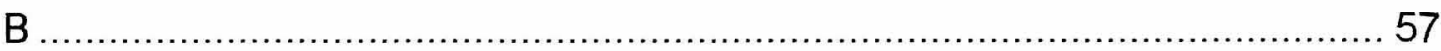

4.4 AVALIAÇÃO DA EXPRESSÃO HEPÁTICA DE P65 ..................................... 58

4.5 AVALIAÇÃO DA EXPRESSÃO HEPÁTICA DE CICLINA D1 .............................. 60

\subsection{AVALIAÇÃO DA EXPRESSÃO HEPÁTICA DO GENE QUE CODIFICA PARA A ENZIMA}

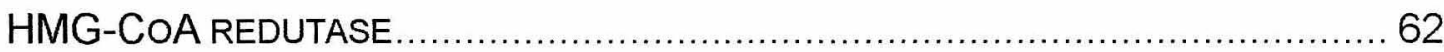

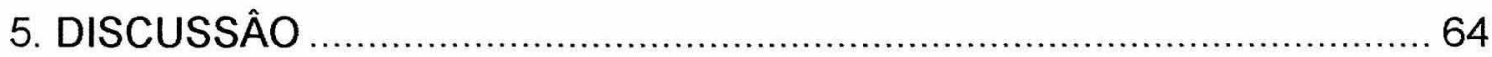

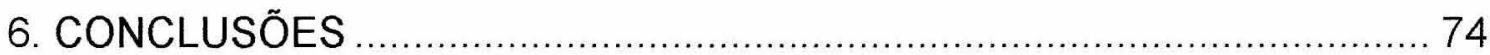

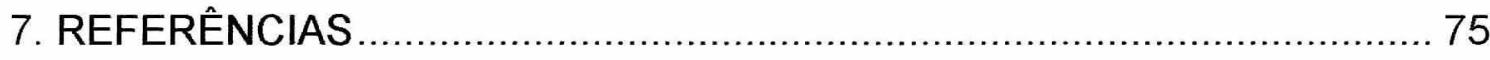

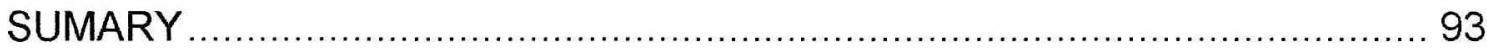




\section{RESUMO}

CHAGAS, C. E. A. O farnesol inibe a proliferação celular e induz a apoptose em ratos Wistar submetidos à hepatectomia parcial. São Paulo, 2006, 93p. Dissertação de Mestrado (Programa de Pós-graduação em Ciência dos Alimentos, área de Nutrição Experimental) - Faculdade de Ciências Farmacêuticas, Universidade de São Paulo.

Diversos estudos epidemiológicos mostram que nutrientes e outros compostos bioativos presentes nos alimentos (CBA) apresentam atividade quimiopreventiva contra o câncer. Assim, destaca-se o estudo dos isoprenóides devido a sua ação promissora tanto na prevenção quanto na terapia do câncer. Todavia, apesar dessas evidências, pouco se sabe a respeito da ação dessas substâncias nos processos de proliferação celular e apoptose in vivo. Assim, 141 ratos Wistar foram tratados durante duas semanas consecutivas com farnesol (grupo FR, $25 \mathrm{mg} / 100 \mathrm{~g}$ de peso corporal) ou óleo de milho (grupo $\mathrm{OM}$; controle, 0,25 mL/100 $\mathrm{g}$ de peso corporal) e sacrificados em diferentes momentos após a hepatectomia parcial (HP; $0 \mathrm{~h}, 30 \mathrm{~min}, 2 \mathrm{~h}, 4 \mathrm{~h}, 8 \mathrm{~h}, 12 \mathrm{~h}, 18$ $\mathrm{h}$ e $24 \mathrm{~h}$ ). Os parâmetros hepáticos analisados foram a proliferação celular (núcleos marcados para $\mathrm{PCNA} / \mathrm{mm}^{2}$ ), apoptose (corpúsculos apoptóticos [CA's] por $\mathrm{mm}^{2}$ ) e expressão de p65, ciclina D1 ("western blot") e HMG-CoA redutase ("dot-blot"). Os animais tratados com o isoprenóide, assim como o grupo controle, apresentaram reduzida taxa de proliferação celular até 8h após a cirurgia. No entanto, a partir desse momento, o grupo FR passou a apresentar taxa de proliferação celular inferior ao grupo OM, diferença esta que atingiu significância estatística $(p<0,05) 24$ h após a HP. Com relação a apoptose, animais tratados com FR apresentaram maior número de CA's $(p<0,05)$ do que o grupo OM 30 min após a HP. Já em relação à ação do FR em âmbito molecular, houve uma redução de $40 \%$ e $50 \%$ na expressão de p65 e ciclina D1 30min e 24h após a HP, respectivamente, embora essas diferenças não tenham atingido significância estatística $(p>0,05)$. Além disso, animais tratados com o isoprenóide apresentaram maior $(p<0,05)$ expressão do gene que codifica para HMG-CoA redutase $2 \mathrm{~h}$ e $12 \mathrm{~h}$ após a cirurgia. Assim, tanto a inibição da proliferação celular quanto a indução de apoptose podem 
ser reflexo das alterações da expressão hepática dos genes para HMG-CoA redutase, p65 e ciclina $\mathrm{D} 1$ por parte do isoprenóide.

Palavras-chave: Hepatectomia parcial, farnesol, proliferação celular, apoptose, NF-kB, ciclina D1, HMG-CoA redutase 


\section{INTRODUÇÃO}

\subsection{Câncer}

O termo câncer se refere a um amplo grupo de complexas doenças caracterizadas por alterações celulares de diferentes origens (Greaves, 2002). Assim, descreve-se a existência de mais de uma centena de cânceres distintos (Hanahan e Weinberg, 2000) que apresentam, de forma geral, expressão gênica alterada em suas células, que proliferam desordenadamente, invadem outros tecidos e comprometem suas funções normais (Fenech, 2002; Loeb et al., 2003).

As mais antigas evidências a respeito da doença se referem a osteomas e hemangiomas encontrados em fósseis de dinossauros (Rotchschild,1999). Relata-se também a ocorrência de cânceres em esqueletos de Homo erectus, o ancestral mais próximo do homem moderno (Capaso e Constantini, 1994).

Além disso, diversos tipos de cânceres foram encontrados em múmias e esqueletos de antigos egípcios, demonstrando que neoplasias malignas não eram raras nessa população. Papiros escritos durante a época das grandes pirâmides (3000 - 2500 a.C.) descreviam vários procedimentos médicos e até mesmo cirúrgicos para tratamento das mais diversas afecções, incluindo o câncer de mama. Da mesma forma, outros papiros mais recentes (1630 a 1350 a.C.) foram encontrados e que prescreviam diversos tratamentos à base de ervas para picadas de insetos, mordidas e cânceres (Tsuchiya e Fujisawa, 1999; Subbarayappa, 2001).

$\mathrm{Na}$ era greco-romana, todos os cânceres eram considerados de origem inflamatória (Retief e Cilliers, 2001). Já Hipócrates (460 - 377 a.C.) utilizou os termos gregos "karkinos" e "karkinoma" para designar aqueles que eram observados na pele, laringe, mama, região inguinal, útero e vagina. Nesses casos, quase todas as lesões se localizavam na superfície do corpo. O tratamento consistia em excisão, cauterização, aplicação de compressas e fomentos. Para os cânceres que eram de origem interna, Hipócrates recomendava que seria melhor não tratar a doença, pois isto poderia antecipar a morte do paciente. Galeno (130 - 200 d.C.) definiu o carcinoma como sendo uma lesão muito dura e maligna, com ou sem úlcera e utilizou o termo câncer. 
Essa palavra, em latim, significa caranguejo, pois se observa que as veias superficiais em determinados tumores de mama são túrgidas e ramificadas, lembrando, desta forma, as patas do crustáceo (Tsuchiya e Fujisawa, 1999).

Atualmente, o câncer é considerado importante problema de saúde pública em diversos países (Jemal et al., 2003), inclusive no Brasil (Kligerman, 2002). Nesse sentido, a Agência Internacional de Pesquisa do Câncer (International Agency for Research on Cancer - IARC; órgão da Organização Mundial da Saúde - OMS) estimou que no ano 2000 ocorreram mais de 10.000.000 de novos casos e cerca de 6.000.000 de mortes por câncer no mundo (IARC, 2003).

Da mesma forma, a Sociedade Americana de Câncer (American Cancer Society - ACS), estima para o ano de 2005 a ocorrência de 1.372 .910 novos casos e cerca de 570.280 mortes por câncer nos EUA. Os cânceres mais freqüentes para homens serão o de próstata, pulmão e cólon. Já para mulheres o de câncer de mama será o mais freqüente, seguido pelos cânceres de pulmão e cólon. Já com relação à taxa de mortalidade por câncer, os principais responsáveis serão os cânceres de pulmão, próstata e cólon em homens, e os de pulmão, mama e cólon em mulheres (ACS, 2005). Nos EUA, uma em cada quatro mortes se deve ao câncer, o que corresponde, inclusive, à segunda causa de mortalidade, sendo antecedida apenas pelas doenças cardiovasculares. Além disso, nos próximos 10 a 15 anos, o câncer deverá se tornar a principal causa de morte nos EUA (Young, 2002).

Já no Brasil, o Instituto Nacional do Câncer (INCA, órgão do Ministério da Saúde) estima que no ano de 2006 ocorram 472.050 novos casos de câncer. Os cânceres com maior incidência para o sexo masculino serão os basocelulares e epidermóides, também chamados de cânceres de pele não melanoma, seguidos pelos de próstata, pulmão, estômago e cólon e reto, enquanto que para o sexo feminino, destacam-se também os basocelulares e epidermóides, mama, colo do útero, cólon e reto, e pulmão (Ministério da Saúde, 2005). Atualmente, o câncer é a segunda causa de mortalidade no Brasil (Sichieri et al., 1996), embora existam projeções de que a doença poderá assumir no futuro o papel de principal causa de morte por doenças na população brasileira (Wünsch Filho e Moncau, 2002). 


\subsection{CARCINOGÊNESE}

Carcinogênese é um termo geral utilizado para se denotar o desenvolvimento da neoplasia (Pitot e Dragan, 1991; Pitot, 2001). Esta pode ser entendida como um aumento autônomo do número de células, independente de estímulos por fatores extra-celulares tais como hormônios, ao contrário da hiperplasia, que por definição consiste na proliferação de células específicas, dependente de tais fatores de estimulação (Bannasch, 1986; Bannasch e Zerban, 1990).

Existem duas amplas classificações das neoplasias, que podem ser benignas ou malignas. As primeiras se referem às que apresentam uma proliferação celular localizada e circunscrita, exercendo pressão nos tecidos adjacentes, mas que não ultrapassam suas divisas. Em contraste, neoplasias malignas ou cânceres têm a capacidade de invadir e se multiplicar em diferentes partes do organismo (Smuckler, 1983).

Já a definição de uma pré-neoplasia deve levar em conta etapas prévias do desenvolvimento de neoplasias tanto benignas quanto malignas. Portanto, uma pré-neoplasia não é idêntica a um pré-câncer, podendo ser descrita em nível histológico, como populações de células fenotipicamente alteradas e que não apresentam natureza neoplásica óbvia, mas que têm possibilidade de progredir para neoplasias benignas ou malignas (Bannasch, 1986).

A carcinogênese consiste em um processo ativo e dinâmico induzido em organismos vivos por agentes de natureza física (carcinogênese física), biológica (carcinogênese biológica) e química (carcinogênese química) (Weisburger et al., 2001; Young et al., 2003).

Tem-se descrito que o desenvolvimento do câncer consiste em um processo longo envolvendo múltiplas etapas na transformação das células normais em malignas, requerendo para isso cerca de 20 a 40 anos, especialmente no caso de tumores sólidos em humanos (Loeb et al., 2003; Steele, 2003). Entretanto, é bastante discutível o número exato de etapas que compõem o processo carcinogênico, existindo evidências que a neoplasia ocorra em três estágios básicos denominados iniciação, promoção e progressão (Pitot; 2001; Young et al., 2003). 
A iniciação, que consiste no primeiro estágio do processo de carcinogênese, envolve alterações genéticas irreversíveis e permanentes na célula afetada (Pitot e Dragan, 1991; Pitot, 2001). Já na promoção ocorre a expansão clonal seletiva das células iniciadas, pela ação de um agente promotor, formando assim lesões pré-neoplásicas (Klaunig et al., 2000; Young et al., 2003). A progressão, último estágio do desenvolvimento neoplásico, é caracterizada pela instabilidade cariotípica e por uma contínua evolução das características independentes, como mudanças bioquímicas nas células malígnas, aumento da proliferação celular, invasão e metástase (Pitot, 2001; Young et al., 2003).

Dessa forma, a proliferação celular desempenha um papel importante, e até mesmo crítico, nas diversas etapas da carcinogênese de diversos orgãos e tecidos, ou seja, na iniciação, promoção e progressão (Tomatis, 1993; Farber, 1995; Mori et al., 1999). 


\subsection{REGENERAÇÃO HEPÁTICA, CICLO CELULAR E APOPTOSE}

O fígado apresenta uma ação central no controle da homeostase metabólica, devido a ser responsável pelo metabolismo, síntese, armazenamento e distribuição de carboidratos, lipídios e vitaminas. Além disso, este órgão produz diversas proteínas plasmáticas como, por exemplo, albumina, proteínas de fase aguda e enzimas (Taub, 2004).

A maioria das funções do fígado é desempenhada pelas células parenquimatosas, ou hepatócitos, os quais representam cerca de $80 \%$ das células hepáticas. Os outros $20 \%$ compreendem as células nãoparemquimatosas, que incluem as células endoteliais, as de Kupffer, as estreladas e os linfócitos (Taub, 2004).

Em condições normais, o fígado encontra-se em estado de quiescência, ou seja, não prolifera. No entanto, tem uma grande capacidade de regenerar-se em resposta a uma injúria tóxica ou ressecção cirúrgica (Koniaris et al., 2003; Taub, 2004).

Essa capacidade de regeneração do fígado foi primeiramente descrita na mitologia grega na lenda de Prometeu que roubou o fogo dos deuses e o entregou ao homem. Como punição, foi amarrado no alto de um penhasco onde um abutre comeria um pedaço de seu fígado diariamente (Koniaris et al., 2003). Assim, devido à capacidade regenerativa do fígado, Prometeu foi condenado a uma tortura eterna.

Para o estudo da proliferação celular hepática existem vários modelos experimentais descritos, cada um deles com suas especificidades no que diz respeito ao tipo de injúria, local e célula que é mobilizada (Tabela 1).

A técnica de HP desenvolvida por Higgins e Anderson em 1931 é um método clássico de estudo da proliferação celular in vivo. Nesse modelo, os lobos esquerdo e médio são retirados, totalizando assim uma ressecção de aproximadamente $70 \%$. O fígado recupera seu tamanho original em um período de aproximadamente 10 dias após a cirurgia (Court et al., 2002; Taub, 2004). Esse é o modelo experimental mais próximo de uma regeneração pura, sem injúria celular, sendo assim preferencialmente utilizado para o estudo da proliferação celular in vivo (Koniaris et al., 2003). 
Após a HP, as células hepáticas deixam o estado de quiescência e iniciam o processo de divisão celular. Os eventos ocorridos nesta fase são chamados de "preparação" (do inglês priming) (Fausto, 2000). Assim, durante o priming, ocorrem respostas hepáticas e sistêmicas fundamentais para uma regeneração hepática adequada. Nesse sentido, o fator de necrose tumoral a (TNF- $\alpha$ ) e a interleucina 6 (IL-6) irão preparar os hepatócitos, ou seja, deixá-los susceptíveis à ação de fatores de crescimento como o fator de crescimento do hepatócito (HGF), fator de crescimento epidermal (EGF) e fator de crescimento transformante a (TGF- $\alpha$ ) (Hui et al., 2002; Koniaris et al., 2003). Assim, os hepatócitos entram imediatamente no ciclo celular passando para a fase $G_{1}$, que tem uma duração aproximada de 12 a 16 horas (Komatsu e Tsukamoto, 1998). A seguir, principia a síntese de DNA que tem duração de cerca de 24 horas após a cirurgia (Iwao e Tsukamoto, 1999). A fase $\mathrm{G}_{2}$ e a mitose (fase $\mathrm{M}$ ) acontecem de 6 a 8 horas após a síntese de DNA (Komatsu e Tsukamoto, 1998). 
TABELA 1: Alguns modelos experimentais disponiveis para estudo da proliferação celular hepática in vivo

\begin{tabular}{|c|c|c|c|c|}
\hline Modelo & Mecanismo & Injúria & Células mobilizadas & $\begin{array}{l}\text { Células mediadoras } \\
\text { da regeneração }\end{array}$ \\
\hline $\begin{array}{l}\text { Tetracloreto de } \\
\text { carbono }\end{array}$ & $\begin{array}{l}\text { Formação de } \\
\text { radicais livres, } \\
\text { peroxidação } \\
\text { lipídica } \\
\text { microssomal e } \\
\text { desagregação } \\
\text { ribossomal. }\end{array}$ & $\begin{array}{l}\text { Necrose } \\
\text { centrolobular, } \\
\text { dano nos } \\
\text { colangiócitos. }\end{array}$ & $\begin{array}{l}\text { Hepatócitos e células } \\
\text { epiteliais do ducto } \\
\text { biliar. }\end{array}$ & $\begin{array}{l}\text { Células epiteliais do } \\
\text { ducto biliar e } \\
\text { hepatócitos. }\end{array}$ \\
\hline Concanavalina A & $\begin{array}{l}\text { Ativação de células } \\
\text { CD4+, indução de } \\
\text { citocinas } \\
\text { inflamatórias e } \\
\text { TGF- } \beta \text {, resultando } \\
\text { em injúria dos } \\
\text { hepatócitos e } \\
\text { apoptose. }\end{array}$ & $\begin{array}{l}\text { Necrose dos } \\
\text { hepatócitos com } \\
\text { fibrose. }\end{array}$ & $\begin{array}{l}\text { Hepatócito e células } \\
\text { estreladas. }\end{array}$ & Hepatócitos. \\
\hline $\begin{array}{l}\text { Metilenodialinina } \\
\text { (DAPM) }\end{array}$ & $\begin{array}{l}\text { Injúria nas } \\
\text { mitocôndrias das } \\
\text { células epiteliais do } \\
\text { ducto biliar. }\end{array}$ & $\begin{array}{c}\text { Hepatite } \\
\text { multifocal, com } \\
\text { necrose e } \\
\text { infiltração de } \\
\text { neutrófilos, } \\
\text { necrose do ducto } \\
\text { biliar e edema } \\
\text { portal. }\end{array}$ & $\begin{array}{c}\text { Hepatócitos e células } \\
\text { epiteliais do ducto } \\
\text { biliar. }\end{array}$ & $\begin{array}{c}\text { Hepatócitos e células } \\
\text { epiteliais do ducto } \\
\text { biliar. }\end{array}$ \\
\hline $\begin{array}{l}\text { Hepatectomia parcial } \\
\text { (HP) }\end{array}$ & $\begin{array}{l}\text { Remoção cirúrgica } \\
\text { de } 2 / 3 \text { da massa } \\
\text { hepática, } \\
\text { resultando em um } \\
\text { aumento no fluxo } \\
\text { portal. }\end{array}$ & $\begin{array}{l}\text { Pouca injúria } \\
\text { hepática e } \\
\text { apoptose. }\end{array}$ & $\begin{array}{l}\text { Hepatócitos, células } \\
\text { epiteliais do ducto } \\
\text { biliar e células não } \\
\text { parenquimatosa. }\end{array}$ & $\begin{array}{l}\text { Hepatócitos, células } \\
\text { epiteliais do ducto } \\
\text { biliar e células não } \\
\text { parenquimatosas. }\end{array}$ \\
\hline $\begin{array}{l}\text { Proliferadores de } \\
\text { peroxissomos }\end{array}$ & $\begin{array}{l}\text { Indução de } \\
\text { proliferação celular } \\
\text { pela ativação de } \\
\text { receptores } \\
\text { nucleares. }\end{array}$ & $\begin{array}{c}\text { Extensa perda } \\
\text { hepática por } \\
\text { apoptose. }\end{array}$ & Hepatócitos. & Hepatócitos. \\
\hline Isquemia/reperfusão & Injúria hepática. & $\begin{array}{c}\text { Apoptose hepática } \\
\text { difusa. }\end{array}$ & Hepatócitos. & Hepatócitos. \\
\hline Nitrato de chumbo & $\begin{array}{l}\text { Indução de } \\
\text { proliferação } \\
\text { principalmente } \\
\text { devido à produção } \\
\text { de TNF-a. }\end{array}$ & $\begin{array}{c}\text { Extensa perda da } \\
\text { massa hepática } \\
\text { por apoptose. }\end{array}$ & Hepatócitos. & Hepatócitos. \\
\hline
\end{tabular}


O TNF- $\alpha$ é uma citocina com ações pleiotrópicas que atua na defesa do organismo, sendo assim necessária à regeneração hepática normal (Koniaris et al., 2003). Essa citocina liga-se a dois receptores localizados na membrana plasmática da célula, TNF-R1 e TNF-R2, sendo o primeiro responsável pelas respostas biológicas induzidas por TNF- $\alpha$. Dessa forma, foi observado que camundongos que não expressam TNF-R1 apresentam uma regeneração hepática lenta. A ligação entre TNF- $\alpha$ e TNF-R1 leva à liberação de uma proteína inibidora de domínios de morte e à formação de um complexo intracelular formado pelo receptor de morte associado ao receptor de TNF (TRADD), pelos domínios de morte (DD), fator 2 associado ao receptor de TNF (TRAF 2), proteína de interação com o receptor (RIP 1) (Figura 1). Assim, esse complexo recruta enzimas específicas necessárias à sinalização celular como caspase-2, quinase do inibidor de NFKB (IKK), ativação do fator nuclear kappa $B(N F \kappa B)$ e quinase da terminação $\mathrm{N}$-terminal da proteína jun (JNK).

A comunicação entre essas vias leva à modulação dos efeitos exercidos pelo TNF- $\alpha$, ou seja, a um balanço entre a apoptose e a proliferação celular. Nesse sentido, sugere-se que o conteúdo celular de espécies reativas de oxigênio e de glutationa pode estar intimamente relacionado com o controle desse balanço (Fausto, 2000; Koniaris et al., 2003; Kamata et al., 2005).

No entanto, o TNF- $\alpha$ e a IL-6 não levam à replicação do DNA (Fausto, 2000). Assim, os hepatócitos necessitam de fatores de crescimento, que são responsáveis pela progressão e término da regeneração hepática. Nesse sentido, o fator de crescimento epidermal (EGF), o fator de crescimento transformante $\alpha$ (TGF- $\alpha$ ) e o fator de crescimento do hepatócito (HGF) são liberados durante o processo de regeneração (Court et al., 2002).

Esses fatores de crescimento podem ser classificados em três diferentes classes, de acordo com sua função (Jesus et al., 2000).

- Agentes mitogênicos completos: são aqueles capazes de induzir a síntese do DNA e a mitose em uma população de hepátocitos quiescentes;

- Agentes mitogênicos incompletos ou co-mitogênicos: auxiliam a indução da sintese do DNA;

- Agentes inibidores do crescimento: controlam o término da proliferação celular. 
O EGF é um mitogênico completo sintetizado pelas células epiteliais e atua na regeneração hepática de forma autócrina. Suas concentrações encontram-se aumentadas poucas horas após a cirurgia. Sua ação é controlada por hormônios como a insulina, o glucagon e a norepinefrina (Jesus et al., 2000; Court et al., 2002).

O TGF- a é produzido principalmente pelas células de Kupffer. É capaz de aumentar a síntese de DNA atuando de forma autócrina (Fausto, 2000). O pico de mRNA para esse fator de crescimento ocorre cerca de 18 a 24 h após a HP (Court et al., 2002). Estudos com ratos que não expressam TGF- $\alpha$, mostram uma ação coadjuvante no processo de regeneração, sendo suas funções exercidas pelo EGF. Todavia, animais que hiperexpressam TGF- $a$ apresentam uma alta taxa de proliferação, mas sem o comprometimento do órgão devido a um aumento na apoptose (Koniaris et al., 2003)

O HGF foi descrito primeiramente como sendo um mitogênico exclusivo para o fígado; no entanto, sabe-se atualmente que esse fator atua em várias células. No fígado, o HGF é produzido pelas células de Kupffer e de Ito em resposta a uma agressão química tóxica ou cirúrgica (Jesus et al., 2000; Court et al., 2002), e atua nos hepatócitos de forma parácrina (Court et al., 2002; Taub, 2004). A expressão do mRNA para HGF começa a aumentar 3 horas após a cirurgia e atinge o máximo cerca de 30 horas. $O$ efeito desse fator de crescimento é totalmente inibido por TGF- $\beta$ e heparina, e potencializado pela norepinefrina (Jesus et al., 2000).

Os agentes mitogênicos incompletos, como a norepinefrina, vasopressina e estrógeno, atuam principalmente potencializando a ação dos mitogênicos completos. No entanto, outros agentes incompletos como a insulina, o glucagon e alguns nutrientes, atuam na regeneração hepática amenizando o estresse provocado pela ressecção do órgão (Jesus et al., 2000)

Uma vez recuperado, o tamanho do fígado é regulado de acordo com as necessidades do organismo; todavia, pouco se sabe a respeito de como o processo de regeneração é encerrado. Provavelmente, o agente inibitório do crescimento mais conhecido seja o TGF- $\beta$ (Taub, 2004). 
FIGURA 1: Via de transdução do sinal mediada por TNF- $\alpha$. TNF- $\alpha$, Tumor Necrosis Factor - fator de necrose tumoral; TNFR1, Tumor Necrosis Factor Receptor 1 - receptor 1 para fator de necrose tumoral; cell membrane membrana celular; DD, Death Domain - domínio de morte; TRADD, TNF Receptor Associated Death Domain - domínio de morte associado ao receptor de TNF; RIP, Receptor Interacting Protein - proteína de interação com o receptor; RAIDD, RIP-Associated ICH-1/Ced-3-homologous protein with Death Domain - Proteína com domínio de morte ICH-1/Ced-3 homóloga associada ao RIP; ASK1, Apoptosis Signal-regulating Kinase 1 - quinase 1 regulada por sinal de apoptose; TRAF2, Tumor Necrosis Factor-associated Death Domain 2 fator 2 associado ao receptor de TNF; CARD, Caspase Recruitment Domain domínio recrutado por caspase; NIK, NFKB Inducing Kinase - quinase indutora de NFKB; JNK, Jun N-terminal Kinase - quinase da porção N-terminal de jun; IKK, I- $\mathrm{KB}$ kinase complex - complexo quinase I- $\mathrm{kB}$; P, phosphate - fosfato; I$\kappa \mathrm{B}$, Inhibitor of $\mathrm{NF}_{\kappa} \mathrm{B}$ - inibidor de $\mathrm{NF} \mathrm{K}_{\mathrm{B}}$; $\mathrm{NF}_{\kappa} \mathrm{B}$, Nuclear Factor Kappa $\mathrm{B}$ - fator nuclear kappa B; SMAC, Second Mitochondrial Activator of Caspases segundo ativador mitocondrial de caspases; DIABLO, Direct IAP-Binding Protein - proteína de ligação direta com IAP; AIF, Apoptosis Inducing Factor fator indutor de apoptose; cytocrome c - citocromo c; apoptosome apoptossomo; apoptosis, apoptose; survival - sobrevivência; proteasomal degradation - degradação por proteassoma; anti-apoptotic gene expression expressão de genes anti-apoptóticos; nucleous - núcleo. Retirado de Ashe e Barry, 2003. 


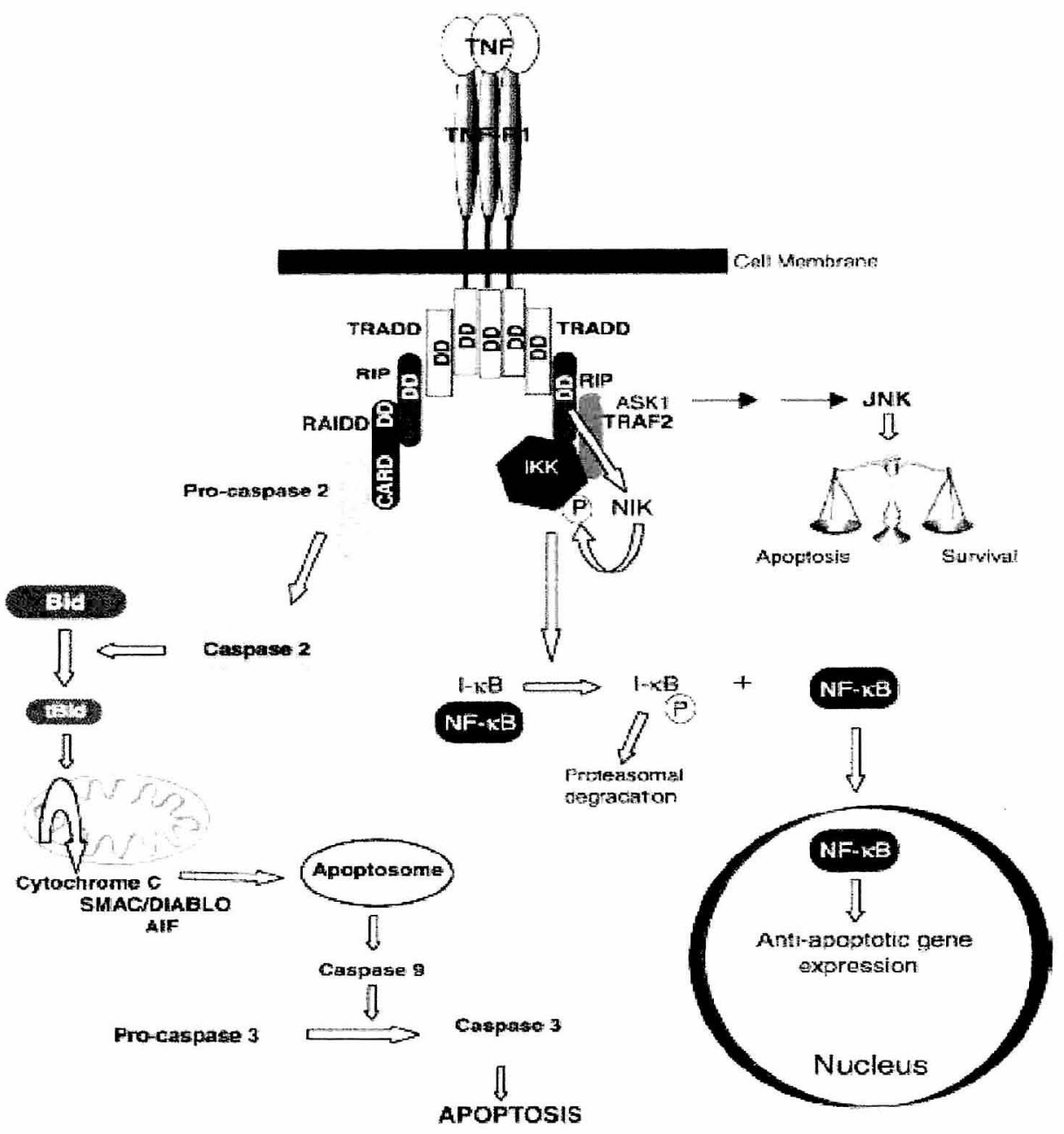


O TGF- $\beta$ compõe uma família composta por mais de 30 membros (Koniaris et al., 2003). Esse agente inibitório é produzido pelos hepatócitos e células não parenquimatosas (Court et al., 2002). Embora suas concentrações estejam aumentadas precocemente após a hepatectomia, não se sabe ainda porque o TGF- $\beta$ não consegue impedir que os hepatócitos progridam até a fase de replicação do DNA. Uma hipótese é que proteínas intracelulares inibam a ação das proteínas SMAD's, que estão a jusante de TGF- $\beta$. As proteínas SMAD's, encontram-se constitutivamente ativas no fígado; porém, sua ativação é aumentada no fígado regenerativo. Da mesma forma, as proteínas inibidoras da via TGF- $\beta-S M A D$ 's, também encontram-se aumentadas após a cirurgia. Essas proteínas atuam como repressores transcricionais, tornando algumas células resistentes a TGF- $\beta$. As concentrações dessas proteínas inibidoras retornam ao normal assim que o fígado recupera o tamanho inicial, enquanto as de SMAD's continuam constantes (Taub, 2004).

Fatores de crescimento, após se ligarem a seus receptores localizados na membrana plasmática, atuam em proteínas do ciclo celular da fase $\mathrm{G}_{1}$. No entanto, para que isso ocorra, os hepatócitos precisam ser sensibilizados. Assim, após a preparação, ocorre a ativação de fatores de transcrição como AP-1 e NFkB, que são fundamentais para transição de $\mathrm{G}_{0}$ para $\mathrm{G}_{1}$ (Pibiri et al., 2001).

Primeiramente descrito em linfócitos $\mathrm{B}$, o NFkB encontra-se presente na maioria das células, incluindo os hepatócitos. No fígado, esse fator de transcrição é formado por duas subunidades, p50 e p65. Quando está em seu estado inativo, encontra-se localizado no citoplasma ligado à sua proteína inibidora IKB (Beg et al., 1992; Beg et al., 1993). Assim, quando o organismo está em situação de estresse, ocorre a fosforilação e posterior degradação de IkB pelo sistema ubiquitina-proteassoma (Figura 2), liberando então o $\mathrm{NF}_{\kappa} \mathrm{B}$ para migrar ao núcleo das células onde este irá ativar genes envolvidos com a inflamação, adesão celular, resposta ao estresse, aumento da proliferação celular e inibição da apoptose (Baldwin, 1996; Ghosh et al., 1998). Após a HP, ocorre uma rápida ativação de NFKB (Taub, 2004), em cerca de 30 minutos, com queda nos niveis cerca de $4 \mathrm{~h}$ após a cirurgia (Fausto, 2000). 
A inibição de NFKB pela expressão aumentada de uma forma modificada de $I_{\kappa} B \alpha$ (I $I_{\kappa} \alpha$ "super-repressor") foi capaz de interromper o ciclo celular em células HeLa na fase $\mathrm{G}_{1}$ tardia, devido à supressão do mRNA para ciclina $\mathrm{D} 1 \mathrm{e}$ da própria proteína. Essa interrupção do ciclo celular ocorreu, ainda, graças a um aumento da expressão de p2 $1^{\text {WAF/CIP1 }}$ (Joyce et al., 2001). Além disso, a inibição de NFKB bloqueou a proliferação celular e induziu uma maciça apoptose em fígados após HP (limuro et al., 1998).

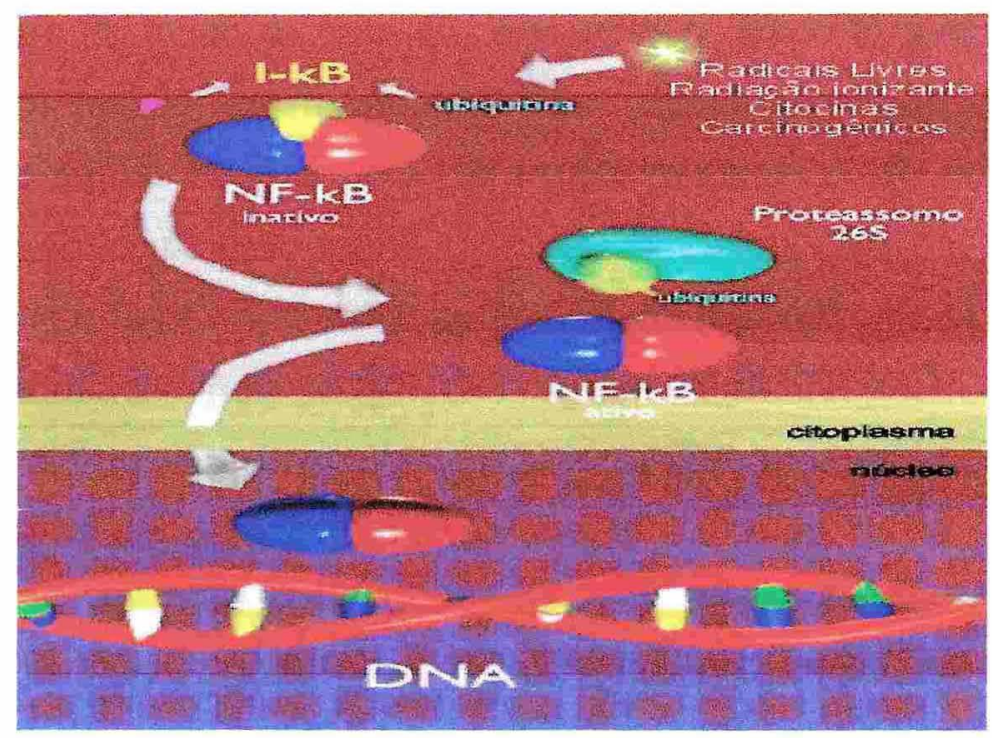

FIGURA 2: Esquema de ativação de NFKB. NFKB, nuclear factor kappa B fator nuclear kappa $B$; I-KB, inhibitor of NFKB - inibidor de NFKB; DNA, desoxiribonocleic acid - acido desoxiribonucléico; $\mathrm{P}$, phosphate - fosfato. Figura elaborada por Rogério P. Mazzantini em 2001.

A progressão do ciclo celular é governada pela ativação, por meio da fosforilação seqüencial de complexos de proteínas quinase compostos de uma subunidade regulatória, a ciclina, e de uma catalítica, a quinase dependente de ciclina (cdk). Os níveis das ciclinas (D, E, A e B) flutuam temporariamente pelas diversas fases do ciclo celular $\left(G_{1}, S, G_{2}\right.$ e $\left.M\right)$, levando à ativação das respectivas cdk's (cdk4/6, cdk2 e cdk1) no momento apropriado (Cartee et al., 2001). 
Além disso, para que as células completem seu ciclo estas devem ultrapassar alguns pontos de avaliação ou de restrição considerados críticos, quando então analisam o contexto extracelular procurando assegurar-se de que apresentam todo o necessário (nutrientes, impulsos mitogênicos etc.) para progredir para a próxima fase do ciclo celular. Assim, o primeiro desses pontos de restrição ocorre em uma etapa tardia da fase $\mathrm{G}_{1}$, quando as células tornamse irreversivelmente comprometidas com a síntese de DNA (fase S) e, conseqüentemente, com a divisão celular (Jones e Kazlauskas, 2001).

Cada ciclina, com sua respectiva cdk, atua em diferentes etapas do ciclo celular. Desta forma, as ciclinas do tipo D, em associação com a cdk4 ou cdk6, são importantes no início da fase $G_{1}$, enquanto a ciclina $E$, junto com a cdk2, age em etapa tardia dessa mesma fase (Boylan e Gruppuso, 2005). O substrato final dessa via é a proteína retinoblastoma $(p R b)$, que consiste no principal alvo do complexo ciclina D1/cdk4. A fosforilação de pRb por esse complexo libera o fator de transcrição E2F, possibilitando, então, a transcrição de genes responsáveis pela progressão da fase $\mathrm{G}_{1}$ para $S$ (Pibiri et al., 2001).

A cascata ciclina D/cdk/retinoblastoma/E2F encontra-se alterada em mais de $80 \%$ das neoplasias humanas devido a alterações na expressão dos genes que codificam para essas proteínas, ou para reguladores à montante da mesma (Ortega et al., 2002). Além disso, a hiperexpressão de ciclina D1 em hepatocarcinomas está relacionada com a malignidade da lesão (Zhang et al., 1993; Joo et al., 2001).

Durante a regeneração hapática, a quantidade de ciclina D1 começa a aumentar cerca de 8 horas após a cirurgia atingindo o máximo em 24 horas. No entanto, a quantidade de cdk4 não apresenta grandes variações como a ciclina D1 (Riniger et al., 1997; Kato et al., 1998; Pibiri et al, 2001). Assim, a ciclina D1 parece ser mais importante para a atividade do complexo ciclina D1/cdk4 durante a progressão do ciclo celular (Kato et al., 1998).

Os complexos ciclina/cdk's são regulados por proteínas de duas famílias: as proteínas INK4 (p16, p15, p18 e p19) e CIP/KIP (p21, p27, p57). A primeira atua dissociando o complexo ciclina D1/cdk4/6, enquanto a segunda atua inibindo a ação do mesmo, na coordenação da síntese de DNA e progressão do ciclo celular por meio da interação com o antígeno nuclear de proliferação celular (PCNA) (Joyce et al., 2001). Após a hepatectomia parcial, a 
concentração de p21 WAF/CIP1 acompanha a de ciclina D1, ou seja, começa a aumentar cerca de 8 horas e atinge o máximo aproximadamente 24 horas após a cirurgia (Riniger et al., 1997; Kato et al., 1998; Pibiri et al, 2001).

A expressão de $\mathrm{p} 21^{\mathrm{WAF} / \mathrm{CIP} 1}$ é controlada por uma outra proteína que atua como fator de transcrição, denominada p53. Codificada pelo gene supressor de tumor p53, essa proteína está envolvida com o controle do ciclo celular, além de participar também no reparo do DNA e no processo de apoptose (Kastan et al., 1991; Stanley, 1995).

Descreve-se que uma mutação de P53 está associada à redução do mRNA para $\mathrm{p} 21^{\mathrm{WAF} / \mathrm{CIP} 1} \mathrm{e}$, conseqüentemente, com o hepatocarcinoma humano (Hui e Makuuchi, 1999).

Atualmente é bem conhecido o mecanismo pelo qual p53 atua interrompendo a fase $\mathrm{G}_{1}$ em resposta a algum dano ao DNA. Assim, estudos utilizando radiação gama demonstraram que o mecanismo antiproliferativo dependente de $p 53$ pode ocorrer devido à indução prolongada de $\mathrm{p} 21^{\text {WAF/CIP1 }}$. A radiação gama ativa p53 que, por sua vez, ativa a transcrição de p21 WAF/CIP1. Este se liga e inibe cdks (cdk4 e cdk6) (Kaufmann e Paules, 1996), prevenindo, desta forma, a hiperfosforilação da proteína retinoblastoma, com conseqüente não liberação de E2F e bloqueio da transição $\mathrm{G}_{1}-\mathrm{S}$ do ciclo celular (Agarwal et al., 1998).

Um outro evento importante e necessário para a progressão do ciclo celular é a via de sinalização mediada pelo oncogene ras (Stacey e Kazlauskas, 2002). A proteína ras é uma proteína G monomérica (do inglês small G protein) que serve como um "interruptor celular", convertendo sinais da membrana celular para o núcleo necessários à estimulação da síntese protéica, proliferação e diferenciação celular (Adjei, 2001)

Em células expostas continuamente a fatores de crescimento, como durante após a HP, a atividade da proteína ras é fundamental durante a fase $\mathrm{G}_{1}$ do ciclo celular (Takuwa e Takuwa, 2001; Stacey e Kazlauskas, 2002). Assim, demonstrou-se que a injeção de um anticorpo anti-RAS em células NIH3T3 tanto antes da estimulação, quanto 6 horas após a adição de fatores de crescimento, resultou em uma potente inibição da síntese do DNA (Mulcahy et al., 1985). 
Além disso, demonstrou-se em células NIH(M17) que a inibição do sinal intracelular mediado por ras bloqueou completamente a fosforilação da proteína retinoblastoma (Takuwa e Takuwa, 1997). Da mesma forma, a superexpressão de p16, inibiu a proliferação celular induzida por ras (Serrano et al., 1995). Assim, uma das funções principais de ras é manter a proteína retinoblastoma em seu estado hipofosforilado. Portanto, descreve-se o complexo ciclina D1/CDK6-6 como um alvo à jusante de ras (Takuwa e Takuwa, 2001).

A apoptose, também denominada morte celular programada, ativa ou fisiológica, consiste em um tipo de morte celular distinta morfologica, bioquímica e molecularmente da necrose, que visa eliminar células em excesso ou indesejáveis, de tecidos embrionários, durante a involução de órgãos e na regressão de neoplasias. Assim, reconhece-se que a apoptose constitui um fenômeno biológico de ampla ocorrência, e que é complementar, mas se opõe à proliferação celular, no sentido de manter a homeostasia tecidual (Bursch et al, 1994; Ueda e Shah, 1994; Columbano, 1995).

Esse processo ocorre pelo estímulo de diversos receptores, os assim chamados receptores de morte. Assim, ao serem estimulados, esses receptores iniciam a cascata de sinalização que ativa as caspases, enzimas que degradam proteínas intracelulares para a manutenção da integridade celular. Além disso, o processo de apoptose envolve a mitocôndria, que libera várias proteínas como o AIF (fator indutor de apoptose), o citocromo c e a proteína DIABLO (proteína ligadora às proteínas inibidoras da apoptose). Assim, o AIF migra para o núcleo, onde promove a condensação da cromatina e a fragmentação do DNA. A proteína DIABLO liga-se, por sua vez, às IAP's (proteínas inibidoras da apoptose), neutralizando sua ação. Já o citocromo c, juntamente com o ATP, ativa a proteína citoplasmática fator 1 de protease apoptótica (apaf-1), formando um complexo chamado de apoptossomo, necessário à ativação de algumas caspases (Green e Reed, 1998; Hengartner, 2000).

A apoptose é intensamente regulada por proteínas da família Bcl-2. (Philchenkov, 2004). Essas podem exercer papel pró ou antiapoptótico e participam de uma ampla variedade de cascatas de sinalização. Interações 
entre proteínas dessa família com outras resultam na morte ou não da célula (Mak e Yeh, 2002).

\subsection{A relação alimentação, nutrição e câncer}

Apesar de hoje ser amplamente difundido, o conceito de que os alimentos podem ajudar a prevenir algumas doenças não é novo. Existem relatos de que Yong-He-Yan, vivendo na China durante a dinastia Song, ou seja, nos anos de 960-1279 d.C, acreditava que uma alimentação deficiente era a causa de um estado que hoje se acredita ser o câncer de esôfago. Além disso, Wiseman sugeriu, em 1676, que o câncer poderia ser decorrente de "um erro alimentar, uma grande acrimônia das carnes e bebida, associado a uma falha na primeira concocção (digestão), recomendando a abstenção de "sal e carnes gordas e temperadas" (World Cancer Research Foundation/American Institute for Cancer Research, 1997).

Posteriomente Lambe (1815) já alertava em seu tratado sobre a alimentação, a respeito do perigo do consumo exagerado de alimentos, em especial o de carnes, no desenvolvimento do câncer e outras doenças crônicas (World Cancer Research Foundation/American Institute for Cancer Research, 1997).

Já em 1849, Bennett, autor de diversos livros médicos, descreveu que as condições relacionadas à obesidade seriam opostas àquelas que resultariam em tendência a desenvolver o câncer (World Cancer Research Foundation/American Institute for Cancer Research, 1997).

Assim, no começo do século passado, Shaw recomendou para diminuir o risco de desenvolvimento de câncer, uma maior ingestão de alimentos de origem vegetal e um menor consumo de alimentos de origem animal, bebidas alcoólicas, chás, bem como evitar o tabagismo (World Cancer Research Foundation/American Institute for Cancer Research, 1997).

Da mesma forma, Williams, em 1908, concluiu que "provavelmente nenhum fator isolado é mais potente na determinação do desencadeamento do câncer em indivíduos predispostos do que a alimentação em excesso". Além disso, como medidas preventivas, o autor ressalta a importância de praticar 
exercícios físicos e de consumir alimentos de origem vegetal (World Cancer Research Foundation/American Institute for Cancer Research, 1997).

Já o fato de que a alimentação poderia influenciar a carcinogênese em animais de experimentação foi observado pela primeira vez por Tannenbaum (1940; 1942a; 1942b). Assim, demonstrou-se que camundongos submetidos a uma restrição alimentar apresentavam menor número de tumores cutâneos espontâneos e/ou induzidos pelo agente benzo[a]pireno do que aqueles alimentados ad libitum. Além disso, também foi demonstrado que animais alimentados com uma ração com alto valor energético e/ou grande quantidade de lipídios tinham mais câncer de mama induzido por carcinogênicos químicos.

Todavia, um maior interesse pelos fatores nutricionais e o desenvolvimento de câncer começou a surgir apenas nas décadas de 60 e 70 do século $\mathrm{XX}$, período este caracterizado por um grande aumento do consumo de carnes e bebidas alcoólicas e um decréscimo no consumo de frutas e cereais.

Assim, estudos epidemiológicos desenvolvidos nesse período investigaram o padrão de incidência na população, a distribuição demográfica e socioeconômica, e os efeitos da migração e dos hábitos alimentares em diferentes grupos populacionais, possibilitando que se concluísse que os fatores nutricionais desempenhavam um papel importante na etiologia $e$, inclusive, na prevenção do câncer. Dessa forma, sugeriu-se que fatores externos, mais do que os genéticos, seriam os responsáveis pelas variações de incidência de câncer observada no mundo.

Neste sentido, Wynder e Gori propuseram em 1977 que poder-se-ia prevenir de 80 a $90 \%$ dos cânceres, e que cerca de $40 \%$ de todos os cânceres em homens e $60 \%$ nas mulheres estariam relacionados com a alimentação.

No entanto, um marco nessa área do conhecimento, foi a revisão publicada em 1981 por Doll e Peto, em que esses epidemiologistas ingleses sugeriram que caso fossem adotadas mudanças na alimentação da população americana, seria possível uma redução de até $70 \%$ na mortalidade causada pelo câncer. Como fatores protetores, esses autores ressaltam a importância dos alimentos fontes de vitaminas antioxidantes e de fibras. Além disso, um elevado consumo de alimentos, gorduras e carnes estaria relacionado com o desenvolvimento de cânceres específicos como os de útero, mama e cólon. 
Mais recentemente foram identificadas algumas substâncias que seriam responsáveis pela diminuição da incidência de câncer observada em indivíduos que consomem quantidades adequadas de vegetais. Dentre essas, destacamse os carotenóides, flavonóides, isoflavonas, curcumin, ácido fólico, retinóides e isoprenóides.

O conceito de quimioprevenção do câncer, definido pela primeira vez por Sporn e colaboradores, pode ser entendido como uma forma de se prevenir a doença pela administração de um ou mais compostos químicos durante as etapas iniciais pré-neoplásicas da carcinogênese, ou seja, nas fases de iniciação ou promoção, antes do estabelecimento da etapa de progressão (Sporn et al., 1976; Wattenberg, 1985; Alberts e Garcia, 1995; Hong e Sporn, 1997; Pezzuto, 1997; Sporn e Suh, 2002).

É grande o número de compostos até agora identificados com eventual atividade quimiopreventiva contra o câncer (Wattenberg, 1985; Boone et al., 1990; Morse e Stoner, 1993; Sharma et al., 1994; Arnold et al., 1995; Alberts e Garcia, 1995; Pezzuto, 1997; Stoner et al., 1997). Dentre esses, diversos são constituintes naturais dos alimentos (Dragsted et al., 1993; Ames et al., 1995; El-Bayoumy et al., 1997; Gescher et al., 1998; Mazzantini et al., 2005).

Nesse sentido, tem aumentado o interesse pelo estudo dos derivados do metabolismo do mevalonato em plantas, denominados isoprenóides, em função de sua ação promissora relatada na quimioprevenção e quimioterapia do câncer (Elson e Yu, 1994; Moreno et al., 1995a; Gould, 1995; Crowell, 1999; Elson et al., 1999; Mo e Elson, 2004). 


\subsection{A VIA DO MEVALONATO}

A via do mevalonato produz além do colesterol, uma série de produtos não esteróis, denominados derivados isoprênicos ou simplesmente isoprenóides. Embora o colesterol seja amplamente estudado pela sua relação com as doenças cardíacas, estudos mostram que os produtos não esteróis produzidos por esta via são essenciais para a sobrevivência das células, surgindo assim, um novo alvo tanto para a prevenção quanto para a terapia do câncer (Elson et al., 1999; Mo e Elson, 2004).

Os isoprenóides denominados "puros" são aqueles constituídos exclusivamente por múltiplos de unidades isoprênicas, como monoterpenos (duas unidades), sesquiterpenos (três unidades), diterpenos (quatro unidades), triterpenos (seis unidades), tetraterpenos (oito unidades) e politerpenos ( $\mathrm{n}$ unidades), enquanto que aqueles denominados "mistos" apresentam, por sua vez, apenas partes de suas moléculas derivadas da via dos isoprenóides (Bach, 1995; Sacchettini e Poulter, 1997) (Figura 3).

Frutas, hortaliças e cereais constituem fontes ricas em derivados do metabolismo do mevalonato (Elson e Yu, 1994). Nesse sentido, encontra-se o monoterpeno $d$-limoneno em óleos essenciais da laranja e outras frutas cítricas (Hakim et al., 2002); álcool perilílico na cereja e hortelã (Crowell, 1999); carvona na hortelã (Crowell, 1999); farnesol na erva cidreira (Rao et al., 2002) e no morango (Tatman e Mo, 2002); geraniol na erva cidreira (Rao et al., 2002), limão (Lota et al., 2002) e no vinho tinto.

Assim, por essa via é formado um número excepcional de isoprenóides encontrados em plantas, podendo-se citar dentre eles o geraniol (GR), farnesol (FR), geranilgeraniol (GGO), esteróis, dolicol, ubiquinona e carotenóides (Stermer et al., 1994; Edward e Ericsson, 1999) (Figura 4).

A primeira etapa na biossíntese de isoprenóides em plantas e do colesterol em animais é a formação do pirofosfato de isopentenila a partir da acetil CoA. Este conjunto de reações inicia-se com a formação de 3-hidroxi-3metilglutaril CoA (HMGCoA), que a seguir é reduzida a mevalonato (Stryer, 1988). A sintese do mevalonato consiste na etapa crítica desse metabolismo, sendo catalisada pela enzima HMGCoA redutase (EC 1.1.1.34) (Stryer, 1988; Shearer e Hampton, 2005). 
Assim, adições sucessivas de unidades isoprênicas, ou seja, pirofosfato de isopentenila formam $\mathrm{GR}\left(\mathrm{C}_{10}\right)$ e $\mathrm{FR}\left(\mathrm{C}_{15}\right)$. A partir desse ponto, essa via metabólica se divide em duas: a primeira envolve a extensão do $\mathrm{FR}$, resultando em cadeias com quantidades aumentadas de unidades isoprênicas, como fitol $\left(C_{20}\right)$, dolicol ( $\left.C_{70-120}\right)$ e borracha $\left(C_{2800-20.000}\right)$, enquanto que a segunda envolve a ligação de dois resíduos de $\mathrm{FR}$, formando o esqualeno $\left(\mathrm{C}_{30}\right)$, que, por sua vez, é convertido ao lanosterol. O colesterol é formado a partir do lanosterol após várias etapas, incluindo a perda de 3 grupamentos metila (Stryer, 1988 Koolman e Rohm, 1996).

Além de diversas outras funções, o colesterol é um dos principais componentes da membrana plasmática. Alem disso, participa de funções envolvidas com o crescimento celular de tecidos normais e malignos (Coleman e Lavietes, 1981; Suaréz et al., 2005). 
FIGURA 3: Via resumida do mevalonato em plantas e mamíferos. HMGCoA, 3hidroxi-3-metilglutaril coenzima A; HMGCoA redutase, 3-hidroxi-3-metilglutaril coenzima A redutase; IPP, pirofosfato de isopentenila; GPP, pirofosfato de geranila; GR, geraniol; FPP, pirofosfato de farnesila, FR, farnesol; GGPP, pirofosfato de geranilgeranila. Adaptada de Bach (1995) e Elson (1995). 


\section{Acetil-CoA}

HMGCoA redutase

Mevalonato

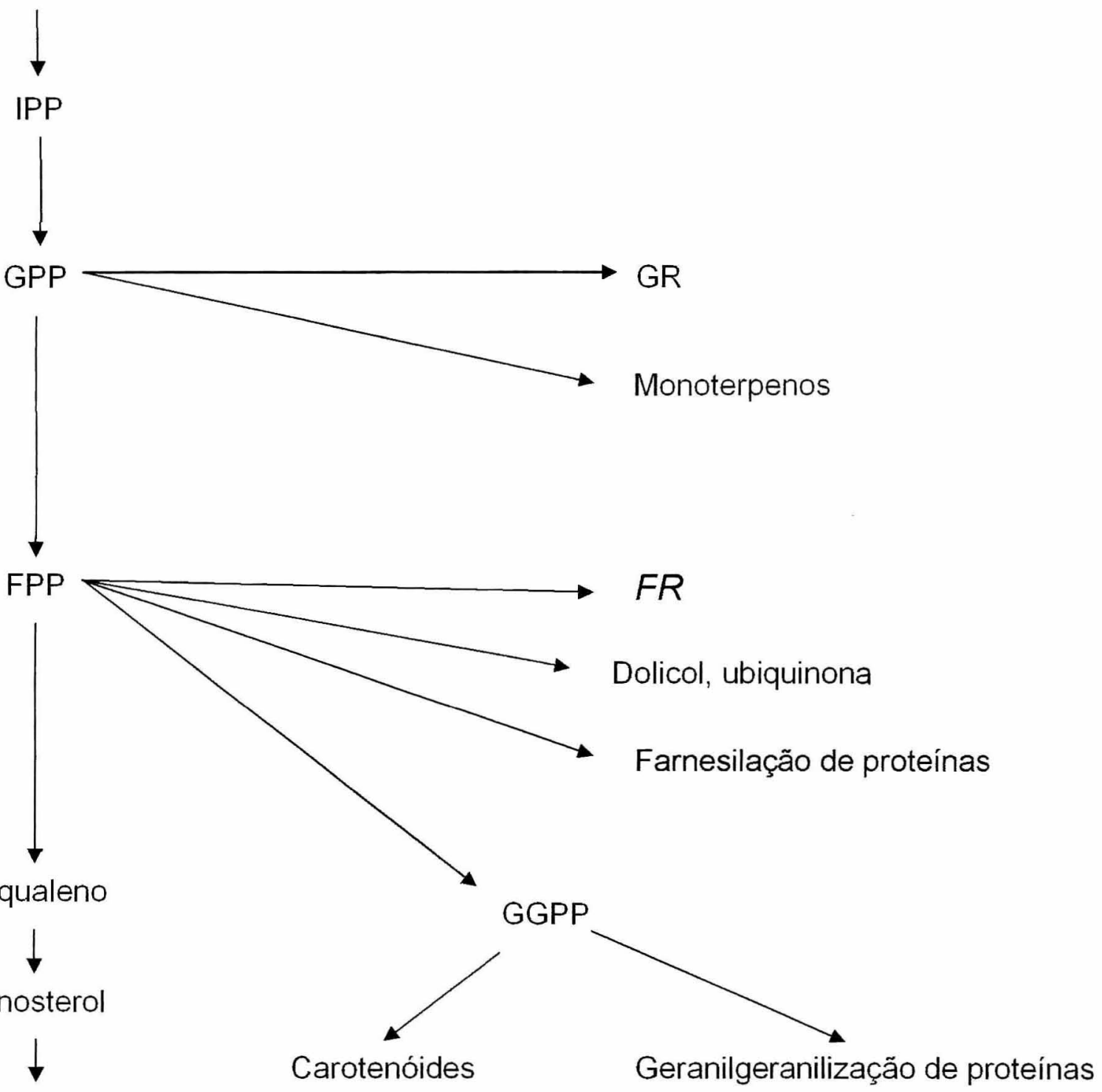

Colesterol 

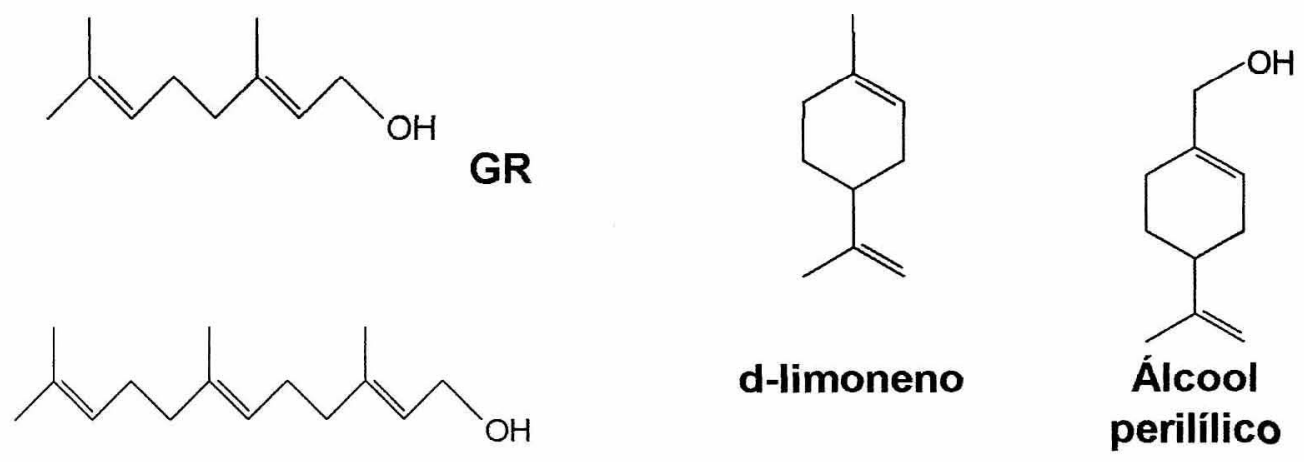

FR

FIGURA 4: Estrutura de alguns isoprenóides. GR, geraniol; FR, farnesol.

Adicionalmente, derivados da via do mevalonato como o pirofosfato de farnesila (FPP) constituem importantes substratos para a promoção da isoprenilação de proteínas envolvidas com a proliferação celular, como laminas nucleares e aquelas codificadas pelo oncogene ras (Marshall, 1993). A prenilação consiste na transferência do grupamento farnesil (15 carbonos) ou geranilgeranil (20 carbonos) para resíduos de cisteínas localizados na porção C-terminal de algumas proteínas (Adjei, 2001). Esse tipo de modificação póstradução aumenta a interação dessas proteínas com os lipídios de membranas (Marshall, 1993), sendo essencial para a função biológica das mesmas (Casey et al., 1989; Hancock et al., 1989. Hennekes e Nigg, 1994).

A HMGCoA redutase constitui uma enzima cuja atividade é uma das mais reguladas na natureza. Em animais esta é modulada por um controle multivalente, sendo reprimida por produtos esteróis como o colesterol, e não esteróis, os derivados do metabolismo do mevalonato (Goldstein e Brown, 1990). Os mecanismos de controle da atividade desta enzima podem envolver a inibição parcial da transcrição do DNA pela ação de esteróis no elemento 1 de resposta a esterol (SER 1), a inibição da tradução do mRNA por isoprenóides não esteróis derivados do mevalonato, e a degradação da enzima via proteólise, estimulada por esteróis e não esteróis atuando conjuntamente (Goldstein e Brown, 1990; Mayer et al., 1991, Mo e Elson, 2004). 
Acredita-se que o FR tenha uma função essencial na modulação da atividade da HMGCoA redutase, por meio da indução de uma protease específica para esta enzima (Shearer e Hampton, 2005), e do controle da síntese da mesma em nível de tradução (Corell et al., 1994; Meigs et al., 1997).

Além disso, observou-se que os níveis de HMGCoA redutase eram proporcionais ao grau de proliferação celular durante o desenvolvimento fetal e neonatal, bem como em neoplasias com diferentes taxas de crescimento (Rao, 1986).

Lesões pré-neoplásicas e neoplásicas do fígado (Siperstein, 1984), bem como de outros tecidos (Siperstein, 1964; Elson et al., 1999; Tatman e Mo, 2002; McAnally et al., 2003) apresentam perda do mecanismo de retroregulação inibitória da atividade da enzima HMGCoA redutase.

A sensibilidade da enzima HMGCoA redutase à regulação inibitória dos isoprenóides é mais elevada em tecidos neoplásicos. Em consequência de tal inibição, estaria limitada a disponibilidade de intermediários derivados da via do mevalonato, necessários à modificação pós-tradução de proteínas relacionadas com a proliferação celular. Essa poderia ser uma possível explicação para a acentuada atividade inibitória do crescimento de neoplasias, constatada após administração de isoprenóides. (Elson, 1994; Elson et al., 1999). Assim, a inibição da via do mevalonato poderia eventualmente se constituir em uma abordagem efetiva para a quimioprevenção e quimioterapia do câncer (Goldstein e Brown, 1990; Elson e Yu, 1994; Elson et al., 1999; Mo e Elson, 2004).

Nesse sentido, Moreno e colaboradores observaram no modelo de hepatocarcinogênese do "Hepatócito Resistente" ( $\mathrm{RH}$, do inglês Resistant Hepatocyte), o potencial quimiopreventivo de diversos derivados isoprênicos, tais como o $\beta$-caroteno (Moreno et al., 1991, 1995a; Rizzi et al., 1997; Dagli et al., 1998; Naves et al., 2001; Fonseca et al., 2005), $\beta$-ionona e GGO (Espíndola et al., 2005), luteína e o licopeno (Toledo et al. 2003) FR e GR (Ong et al., 2005), vitamina $A$ e ácidos retinóicos 9-cis e todo trans (Fonseca et al., 2005) observando efeito quimiopreventivo, envolvendo principalmente a inibição da proliferação celular.

Da mesma forma, He et al. (1997) testaram diversos isoprenóides quanto a seus respectivos potenciais de inibição da proliferação de células da 
linhagem B16 de melanoma muríno, verificando que os inibidores mais potentes foram, neste caso, os tocotrienóis e o FR.

Posteriormente, Mo e Elson (1999) observaram que o $\gamma$-tocotrienol e a $\beta$ ionona suprimiram a proliferação de células B16 de camundongos, bem como de células leucêmicas HL-60, de adenocarcinomas de mama (MCF-7) e de cólon (Caco-2) humanos. Nesses casos, o tratamento com isoprenóides resultou em um bloqueio do ciclo celular em $\mathrm{G}_{1}$ e em estímulo da apoptose.

Mais recentemente, estudos demonstraram ter sido o FR, dentre diversos isoprenóides, o inibidor mais potente da proliferação de células B16 de melanoma e células leucêmicas HL-60 de humanos (Mo et al., 2000; Tatman e Mo, 2002). Observou-se, também, que o tratamento com FR foi acompanhado de bloqueio do ciclo celular na fase $\mathrm{G}_{1}$.

Da mesma forma, Ong et al., (2005) mostraram que o tratamento com FR (25 mg/100 g de peso corporal) em ratos Wistar submetidos ao modelo de hepatocarcinogênese do $\mathrm{RH}$, apresentou atividade quimiopreventiva maior do que $\circ$ GR. Constatou-se, ainda, que os dois isoprenóides inibiram a proliferação celular nessas condições experimentais, o que sugere que o potencial quimiopreventivo de ambos esteja relacionado a esta propriedade dos mesmos.

Já quanto à ação de isoprenoides no âmbito molecular, Espíndola e colaboradores observaram que o GGO (16 mg/100g bw) foi capaz de inibir a ativação de NFKB em fígado de ratos Wistar também submetidos ao modelo do $\mathrm{RH}$ (Espíndola et al., 2005). Além disso, diversos estudos mostraram que o álcool perilílico, o GR e a lovastatina atuam diminuindo as concentrações de ciclina D1 e aumentando a de P21 WAF/CIP1 (Mo e Elson, 2004).

Além disso, existem evidências que mostram que o FR além de inibir a proliferação celular, também atuaria no processo de apoptose (Voziyan et al., 1995; Rioja et al., 2000).

Desse modo, a supressão do crescimento de neoplasias pelos isoprenóides parece estar relacionada à inibição da proliferação celular, bem como a um estímulo da apoptose, (Elson, 1995; He et al., 1997, Mo e Elson, 1999; Mo e Elson, 2004), apesar de serem escassas as referências na literatura quanto a investigações em animais de experimentação. 
Nesse sentido, Burke et al. (1997) avaliaram in vivo a ação anticarcinogênica do GR, do álcool perilílico e do FR. Em um primeiro experimento forneceu-se a hamsters rações contendo $20 \mathrm{~g} / \mathrm{Kg}$ de GR ou FR, ou $40 \mathrm{~g} / \mathrm{Kg}$ de álcool perilílico, durante uma semana antes do transplante de células PC-1 de carcinomas ductais pancreáticos até o término do estudo, que teve uma duração de 25 dias. Em um segundo experimento transplantou-se, inicialmente, essas mesmas células em hamsters, e após o desenvolvimento de tumores palpáveis, os animais receberam rações contendo $20 \mathrm{~g} / \mathrm{Kg}$ de GR ou FR. Em ambos os experimentos, essas duas últimas substâncias inibiram completamente o crescimento das neoplasias, verificando-se, ainda, a regressão de algumas delas. No $1^{\circ}$ experimento, tanto o GR como o FR foram nesse sentido mais potentes do que o álcool perilílico. Esses efeitos ocorreram sem o desenvolvimento de toxicidade significante nos animais, e sem alteração na concentração plasmática de colesterol total. De acordo com os autores isso poderia indicar que o mecanismo de ação dessas substâncias não envolveu a inibição da atividade da enzima HMGCoA redutase, mas sim um estímulo da apoptose. Assim, mais recentemente, o mesmo grupo descreveu que o FR induziu apoptose em neoplasias hiperplásicas do ducto pancreático, com aumento da proteína pró-apoptótica Bak e diminuição da proteína antiapoptótica Bcl-XL (Burke et al., 2002).

Assim, de forma geral, as ações anticarcinogênicas de isoprenóides têm sido relacionadas à inibição da proliferação celular e estímulo da apoptose, decorrentes da supressão da via do mevalonato em lesões pré-neoplásicas e neoplásicas. Mais especificamente, descreve-se que a retroalimentação inibitória da atividade da enzima HMGCoA redutase por isoprenóides, com conseqüente redução da produção de intermediários como o pirofosfato de farnesila e de geranilgeranila, resultaria em menor prenilação protéica, menor ativação de ras e laminas nucleares e, desta forma, em bloqueio do ciclo celular na fase G1. Além disso, as células que eventualmente prosseguissem no ciclo celular seriam eliminadas por apoptose (Elson, 1995; He et al., 1997; Mo e Elson, 1999; Liu et al., 2004).

Apesar de se ter demonstrado ações inibitórias por parte de isoprenóides em alguns modelos de carcinogênese (Yu et al., 1995; Wargovich et al., 2000; Burke et al., 2002; Rao et al., 2002; Ong et al., 2005), não existem, 
entretanto, descrições na literatura a respeito de eventuais mecanismos moleculares responsáveis por tais ações, principalmente quanto à proliferação celular.

Assim, pretendeu-se neste estudo avaliar as eventuais atividades do FR na proliferação e apoptose quando administrado durante 2 semanas consecutivas a ratos Wistar submetidos a HP. Além disso, para a investigação de possíveis mecanismos que poderiam estar relacionados com estas atividades, também foram avaliadas a expressão hepática dos genes para NF$\mathrm{KB}$, ciclina D1 e HMG-CoA redutase. 


\section{OBJETIVOS}

\subsection{Objetivo geral}

- Avaliar o efeito do FR nos processos de proliferação celular e apoptose hepáticas de ratos Wistar submetidos à HP. 


\subsection{Objetivos especificos}

- Avaliar a expressão hepática de NF-kB dos animais tratados durante duas semanas consecutivas com FR e sacrificados em diferentes momentos após a HP;

- Avaliar a expressão hepática de ciclina D1 dos animais tratados com FR durante duas semanas consecutivas e sacrificados em diferentes momentos após a HP.

- Avaliar a expressão hepática do gene que codifica para a enzima HMG-CoA redutase dos animais tratados com FR durante duas semanas consecutivas e sacrificados em diferentes momentos após a HP. 


\section{MATERIAL E MÉTODOS}

\subsection{Animais}

Foram utilizados 141 ratos machos, albinos, da linhagem Wistar, com pesos iniciais compreendidos entre 250 e $300 \mathrm{~g}$ e obtidos da colônia do biotério da Faculdade de Ciências Farmacêuticas/Instituto de Química da Universidade de São Paulo. Esses animais foram mantidos em gaiolas de polipropileno (no máximo 5 ratos/gaiola) com tampas de aço inoxidável e contendo maravalha previamente esterilizada, trocada em dias alternados.

Durante todo o período experimental, os animais receberam ad libitum água e ração comercial peletizada comum para roedores de laboratório (Purina Nutrimentos Ltda., Campinas, Brasil).

O ensaio biológico foi realizado nas dependências do biotério da FCF/IQ-USP, em ambiente com temperatura $\left(22 \pm 2^{\circ} \mathrm{C}\right.$ ), luz (ciclo claro-escuro de 12 h) e umidade (60\%) controladas.

\subsection{Modelo de proliferação celular}

Como modelo de proliferação celular in vivo, foi utilizado o procedimento cirúrgico descrito por Higgins e Anderson em 1931. Assim, os animais foram anestesiados com éter etílico (Merck, Alemanha) para a retirada em seguida dos lobos esquerdo e médio, totalizando assim cerca de $70 \%$ do fígado, deixando os restantes $30 \%$ intactos.

\subsection{Protocolo experimental}

Para se avaliar as atividades do FR na proliferação celular e apoptose, os animais foram submetidos aos procedimentos especificados abaixo: 
- Avaliação das atividades do FR na proliferação celular e apoptose, quando administrados durante 2 semanas consecutivas, em ratos Wistar submetidos à hepatectomia parcial

Após um período de aclimatação de sete dias, 141 animais foram distribuídos aleatoriamente em 2 grupos experimentais (Figura 5):

- Grupo OM: os animais deste grupo foram tratados com óleo de milho (Mazola®) na dose de $0,25 \mathrm{~mL} / 100 \mathrm{~g}$ de peso corpóreo, por intubação gástrica, diariamente, durante 2 semanas consecutivas. Após esse período de tratamento, esses animais foram submetidos à HP conforme descrito anteriormente (ver item 4.2).

- Grupo FR: os animais deste grupo foram tratados com farnesol (trans, trans -farnesol; F 3666; 96\%, Aldrich $®$, EUA), na dose de 25 $\mathrm{mg} / 100 \mathrm{~g}$ de peso corpóreo, dissolvido em óleo de milho (Mazola®; $0,25 \mathrm{~mL} / 100 \mathrm{~g}$ de peso corpóreo) por intubação gástrica, diariamente durante duas semanas consecutivas. Após esse período de tratamento, esses animais foram submetidos à HP conforme descrito anterormente (ver item 4.2).

\subsection{Sacrifício}

Por ocasião do sacrifício os animais foram anestesiados com éter etílico e, a seguir, sacrificados por exsanguinação após punção da artéria aorta abdominal. Os sacrifícios ocorreram em diferentes momentos: 0 h, 30 min, $2 \mathrm{~h}$, $4 \mathrm{~h}, 8 \mathrm{~h}, 12 \mathrm{~h}, 18 \mathrm{~h}$ e $24 \mathrm{~h}$ após a HP. Em cada um desses momentos os animais tiveram os seus respectivos fígados coletados para posteriores análises.

Todos os procedimentos experimentais realizados foram aprovados pela Comissão de Ética para Experimentação Animal da Faculdade de Ciências Farmacêuticas da Universidade de São Paulo (Protocolo $n^{\circ} 16$ ) 


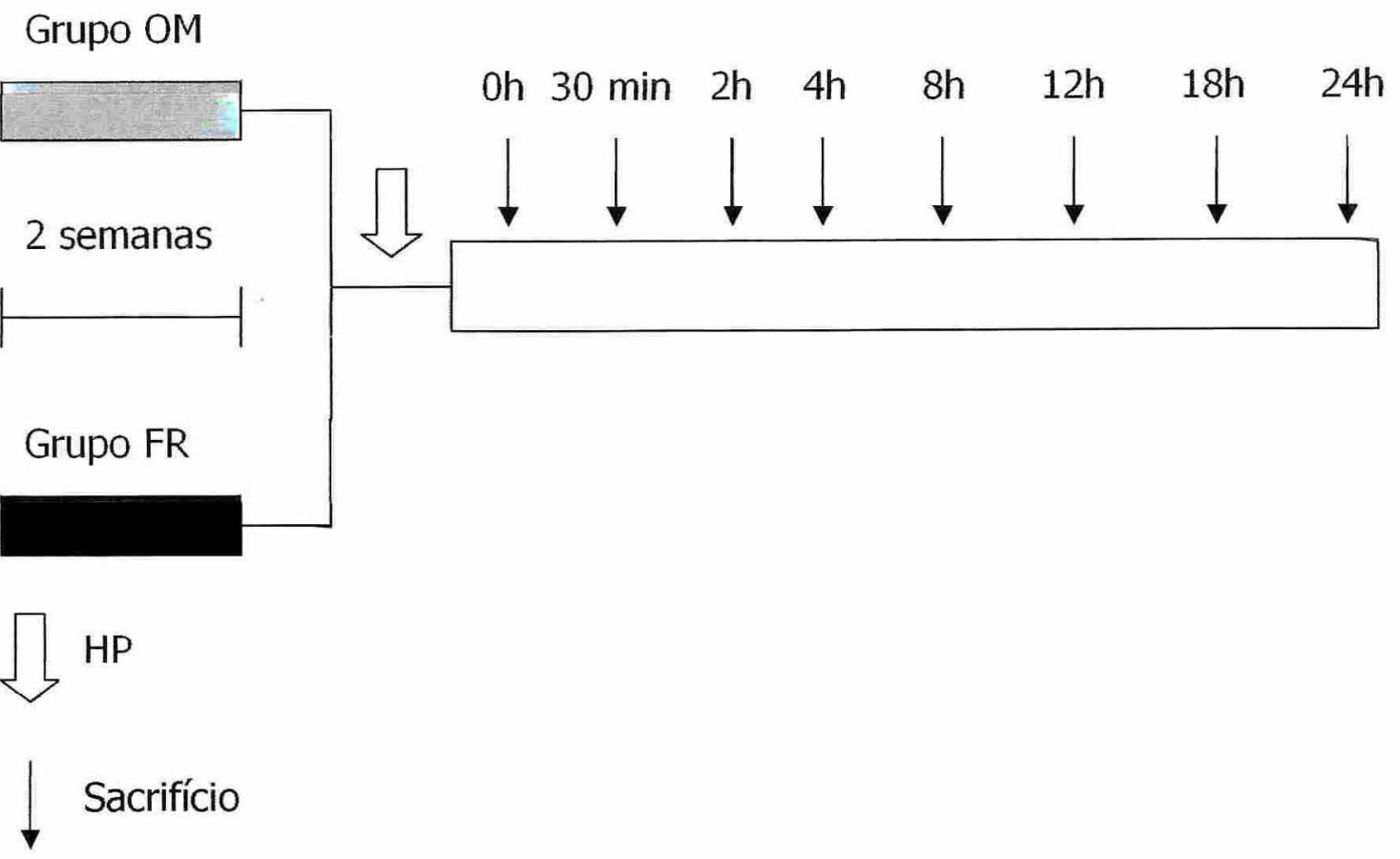

Figura 5: Representação esquemática do protocolo experimental para avaliação das atividades do FR na proliferação celular, apoptose e na expressão hepática dos genes para p65, ciclina D1 e HMG-CoA redutase, em ratos Wistar tratados durante duas semanas consecutivas com o isoprenóide e submetidos à hepatectomia parcial. OM, óleo de milho; FR, farnesol; HP, hepatectomia parcial.

\subsection{Exames Microscópicos}

Foram colhidas de cada animal amostras dos lobos hepáticos remanescentes. Esses fragmentos foram imediatamente fixados em metacarn ( $60 \%$ metanol, $30 \%$ clorofórmio e $10 \%$ ácido acético glacial; Merck $®$, Brasil) por aproximadamente $24 \mathrm{~h}$., sendo, então, submetidos às técnicas rotineiras de desidratação, diafanização e inclusão em parafina.

Para as análises microscópicas foram obtidos cortes histológicos de aproximadamente $5 \mu \mathrm{m}$ de espessura da massa hepática restante após a cirurgia, utilizando-se, para tanto, o criostato Cryocut 1800 (Reichert-Yung; Alemanha) do Laboratório de Oncologia Experimental do Departamento de 
Patologia da Faculdade de Medicina Veterinária e Zootecnia da Universidade de São Paulo.

\subsubsection{Avaliação da proliferação celular}

Para a avaliação da proliferação celular hepática, cortes histológicos foram marcados por imunoistoquímica para o Antígeno Nuclear de Proliferação Celular (PCNA) conforme descrito previamente (Hsu et al., 1981; Fonseca et al., 2005) empregando-se, para tanto, anticorpo primário policlonal anti-PCNA (PCNA: clone PC 10, code $\mathrm{n}^{\circ}$. M0879 DAKO®) e anticorpo secundário biotinilado anti-imunoglobulina de coelho (LSAB K0690, DAKO®). Esse último consiste em anticorpo anti-lgG conjugado à biotina.

Cada procedimento foi intercalado por lavagem das lâminas em solução salina tamponada com fosfato (PBS-[NaCl, $\mathrm{KCl}, \mathrm{Na}_{2} \mathrm{HPO}_{4}$ e água ultra-pura], ph $=7,4)$.

Os cortes histológicos foram desparafinizados em xilol em seqüência de xilol/álcool (1:1), etanol absoluto, a $95 \%$ e a $70 \%$ e, finalmente, água destilada.

A peroxidase endógena foi bloqueada incubando-se as lâminas por 30 min. em metanol (Merck®, Alemanha) contendo 30\% de peróxido de hidrogênio a 30 volumes (Merck®, Alemanha). Os cortes foram então incubados com o anticorpo primário anti-PCNA na diluição de 1:1600 durante uma noite na temperatura de $4^{\circ} \mathrm{C}$ em câmara úmida. Para diluir o anticorpo primário, foi utilizada solução contendo $0,5 \mathrm{~mL}$ de albumina à $5 \%$ (albumina bovina fração V; Sigma, EUA), 0,5 mL de azida sódica à $5 \%$ (LabSynth®, Brasil) e $12 \mathrm{~mL}$ de PBS.

Em seguida, esses cortes foram incubados com o anticorpo secundário conforme instruções do fabricante.

Posteriormente, foi aplicada sobre os cortes uma solução substrato de peroxidase preparada imediatamente antes da utilização. Essa solução consistiu na mistura de peróxido de hidrogênio a 0,02\% (Merck®, Brasil) com diaminobenzidina (Sigma®, EUA) a 0,1\% em PBS. Os cortes foram lavados em PBS por 5 min., contracorados pela hematoxilina, desidratados, diafanizados e montados com resina sintética. 
Foram considerados para a leitura, os núcleos positivos para PCNA que se encontravam nas fases $\mathrm{G} 1$ e $\mathrm{S}$ do ciclo celular. Os resultados estão apresentados em número de núcleos marcados por $\mathrm{mm}^{2}$ de área de corte.

\subsubsection{Avaliação da Apoptose}

Cortes histológicos de fígados foram corados com hematoxilina de Harris e Eosina (H\&E), basicamente como descrito por Junqueira e Junqueira (1983).

Para a avaliação da apoptose em cortes histológicos de fígado de rato empregou-se método de microscopia de fluorescência descrito por Stinchcombe et al. (1995). Este baseia-se na observação de que corpúsculos apoptóticos (CA) apresentam intensa fluorescência da eosina em cortes histológicos de fígado corados com H\&E e submetidos à luz no comprimento de onda entre 450 e $490 \mathrm{~nm}$. Assim, utilizou-se a objetiva com aumento de 40x do microscópio de epifluorescência (Nikon, Japão) (laboratório de Imunologia Clínica, FCF-USP) para quantificar o número de CA em todo o corte. Conforme os corpúsculos fluorescentes eram localizados, alternava-se o sistema para a luz normal e suas identidades eram, então, confirmadas de acordo com critérios morfológicos clássicos (corpúsculos acidofílicos arredondados separados das células adjacentes) descritos na literatura (Grasl-Kraupp et al., 1994). Os resultados foram expressos como $n^{0}$ de $\mathrm{CA} / \mathrm{mm}^{2}$ de área de tecido analisado.

\subsection{Avaliação da expressão hepática de p65 e ciclina D1}

\subsubsection{Obtenção do extrato protéico total hepático}

Para a obtenção do extrato protéico total hepático foram pesados cerca de aproximadamente $100 \mathrm{mg}$ de tecido previamente armazenado a temperatura de $-80^{\circ} \mathrm{C}$. Após a pesagem, homogeneizou-se esse tecido diretamente em tampão específico para extração de proteínas T-PER ${ }^{\circledR}$ (Pierce®, EUA) na proporção de $1 \mathrm{~mL}$ de reagente para cada $300 \mathrm{mg}$ de tecido. Posteriormente, acrescentou-se um volume de solução a $10 \%$ de SDS 
igual ao de T-PER ${ }^{\circledast}$. Finalmente, as amostras foram fervidas por $10 \mathrm{~min}$ e armazenadas à temperatura de $-80^{\circ} \mathrm{C}$ até o momento do uso.

\subsection{2 "Western blot"}

Amostras de extratos protéicos totais hepáticos foram separadas por eletroforese em gel desnaturante de poliacrilamida (SDS-PAGE), em tampão Tris-glicina $1 \mathrm{X}$, utilizando-se um sistema de eletroforese vertical (Hoefer® mini VE Electrophoresis System) mantendo voltagem a $120 \mathrm{~V}$ e amperagem a 250 mA. Para a transferência das proteínas do gel para membranas de nitrocelulose (Amershan Bioscience ${ }^{\circledR}$, Inglaterra), utilizou-se o mesmo sistema de eletroforese (Hoefer $\AA$ mini VE Electrophoresis System), porém alterando a voltagem e a amperagem para $25 \mathrm{~V}$ e $350 \mathrm{~mA}$, respectivamente, por cerca de $1,5 \mathrm{~h}$. Após a transferência, foi retirada parte da membrana para posterior normalização da expressão.

O bloqueio das membranas de nitrocelulose foi feito com uma solução de leite desnatado a $5 \%$ para p65 ou $1 \%$ de albumina para ciclina D1, ambos em PBS, durante uma noite a $4^{\circ} \mathrm{C}$, ou $1 \mathrm{~h}$ em temperatura ambiente, respectivamente. Após a lavagem das membranas para retirar o excesso de leite ou albumina, as mesmas foram incubadas com o anticorpo primário policlonal p65 (diluição 1:1000, SC-372 [Santa Cruz®, EUA]) ou anti-ciclina D1 (diluição 1:100, SC-718 [Santa Cruz®, EUA]) diluídos em solução de tampão PBS com leite desnatado (concentração de $0,5 \%$ ) ou albumina (concentração de $0,1 \%$ ), por $2 \mathrm{~h}$ em temperatura ambiente, sob leve agitação em agitador mecânico (Amersham Biosciences $\AA$, Inglaterra). As membranas foram lavadas com solução PBS-T (PBS adicionado 1\% de Tween 20 [Amersham Biosciences $₫$, Inglaterra]) para retirar o excesso de anticorpos, sendo, então, incubadas por $1 \mathrm{~h}$. em temperatura ambiente com o anticorpo secundário conjugado com peroxidase (anti-IgG de cabra [SC-2020, Santa Cruz, USA] ou coelho [Amershan Bioscience ${ }^{\circledR}$, Inglaterra]), em PBS. Foi repetida a lavagem da membrana com tampão PBS-T e, a seguir, foi feita a revelação usando o "kit" ECL (Enhanced Chemiluminescence, [Amersham Biosciences $\otimes$, Inglaterra]). 
Para a normalização da expressão, a parte da membrana retirada após a etapa de transferência foi corada com "Coomassie Blue" (Pierce®, EUA), e a expressão foi normalizada de acordo com a quantidade de proteína carregada no gel (Tao et al., 2002; Espíndola et al., 2005). A leitura das bandas foi realizada comparando-se a intensidade das mesmas obtida por meio de densitômetro (modelo GS-700, BioRad®, EUA).

\subsection{Avaliação da expressão do gene que codifica para a enzima} HMG-CoA redutase pela técnica de "Dot blot"

Para a avaliação da expressão do gene que codifica para a enzima HMG-CoA redutase, foram utilizadas amostras de fígado obtidas por ocasião do sacrifício armazenadas a temperatura de $-80^{\circ} \mathrm{C}$.

Para a extração do RNA total hepático, utilizou-se reagente específico (Trizol $^{\mathrm{tm}}$, Gibco, EUA). Assim, foram pesados $500 \mathrm{mg}$ de fígado, aos quais se adicionou $5 \mathrm{~mL}$ de reagente. Incubou-se a amostra por 5 minutos a $30^{\circ} \mathrm{C} \mathrm{e}$, em seguida, adicionou-se às mesmas $1 \mathrm{~mL}$ de clorofórmio (Sigma, EUA). A amostra foi então agitada (agitador do tipo vortex) e centrifugada a $9000 \mathrm{~g}$ por 15 minutos a $4^{\circ} \mathrm{C}$. À fase aquosa, transferida para um outro tubo previamente autoclavado, adicionou-se 2,5 mL de isopropanol (Sigma, EUA). O RNA total foi precipitado durante uma noite a $-20^{\circ} \mathrm{C}$ e coletado por meio de centrifugação a $9000 \mathrm{~g}$, por 10 minutos a $4^{\circ} \mathrm{C}$. O sobrenadante foi removido e o precipitado lavado com etanol a $75 \%$. O RNA total obtido foi dissolvido em $400 \mu \mathrm{L}$ de SDS a $0,5 \%$.

Para a realização da técnica de "Dot blot", utilizou-se basicamente a metodologia descrita por Di Groce et al. (1996) e Sambrook e Russel (2002). Assim, $75 \mu \mathrm{L}$ de RNA total de cada amostra foram transferidos para membrana de nylon (Hybond XL, Amersham Bioscience, EUA) utilizando-se, para tanto, aparato específico para análise de "dot blot" (Bio Rad, EUA) acoplado à bomba de vácuo. O RNA total transferido para a membrana foi fixado em unidade de UV Crosslinker (Hoefer, EUA), aplicando-se $120 \mu \mathrm{J} / \mathrm{cm}^{2}$ de área.

A membrana contendo as amostras de RNA total foi submetida à préhibridização em solução contendo formamida, SSC, ficol, polivinilpirrolidona, albumina bovina fração V, SDS e DNA de esperma de salmão. Esta etapa foi 
conduzida por $4 \mathrm{~h}$ e à temperatura de $42^{\circ} \mathrm{C}$ em forno de hibridização (Amersham Bioscience, Inglaterra). Em seguida, adicionou-se à solução de pré-hibridização $150 \mathrm{ng}$ de sonda de plasmídio para HMG-CoA redutase, clonado em bactéria $E$. Coli $E 1$, previamente marcado com $5 \mu \mathrm{L}$ de fósforo radioativo $\left[\left(\mathrm{P}_{32}\right)\right.$, Amersham Bioscience $®$, Inglaterra] pelo método de random priming. A hibridização ocorreu a $42^{\circ} \mathrm{C}$ durante 42 horas. A membrana foi lavada 3 vezes com solução contendo SSC e SDS [ $1^{\circ}$ lavagem $(10 \mathrm{~min} ; 80 \mathrm{~mL}$ de SSC $20 x$ e $20 \mathrm{~mL}$ de SDS 20\%), $2^{\circ}$ lavagem (10 min; $80 \mathrm{~mL}$ de SSC e $4 \mathrm{~mL}$ de SDS 20\%), $3^{\circ}$ lavagem (15 min; $4 \mathrm{~mL}$ de SSC 20x e $20 \mathrm{~mL}$ de SDS 20\%)]. Posteriormente, essa membrana foi acondicionada junto à um filme fotográfico de raio $\mathrm{X}$ (X-OMAT-K Eastman Kodak Co., Nova York, EUA) e chassi radiográfico (Écran intensificador de imagem, base verde; Konex, Brasil) por cerca de 7 dias. Após esse período, o filme foi então revelado.

Os sinais identificados por auto-radiografia foram analisados em sistema de análise densitométrica (modelo GS-700, Bio Rad, EUA). Como controle de aplicação das amostras de RNA total, corou-se a membrana com azul de metileno.

\subsection{Análise estatística}

Para a verificação de diferenças entre os diferentes momentos de sacrifício em cada um dos grupos experimentais, utilizou-se o teste one-way ANOVA seguido do teste de Tukey. Já para verificar a existência de diferenças entre os grupos FR e controle (grupo OM), utilizou-se o teste two-way ANOVA seguido do teste de Tukey. Em ambos os casos, o nível de confiança adotado foi de $95 \%(p<0,05)$. 


\section{RESULTADOS}

\subsection{Pesos Corpóreos Inicial e Final, bem como Peso do Fígado por Ocasião do Sacrifício e Consumo de Ração dos Animais Submetidos ao Protocolo Experimental}

A Tabela 2 apresenta os resultados relativos aos pesos corpóreos inicial e final, bem como o peso do fígado por ocasião do sacrifício, e ao consumo de ração de ratos Wistar tratados OM (grupo OM, controle) ou FR (grupo FR), durante 2 semanas consecutivas e submetidos à HP

TABELA 2*: Pesos corpóreos iniciais e finais, bem como consumo médio de ração de ratos Wistar tratados com OM ou FR durante 2 semanas consecutivas e submetidos à HP.

\begin{tabular}{|c|c|c|c|c|}
\hline Grupo & $\mathbf{n}$ & Peso corpóreo inicial (g) & Peso corpóreo final (g) & $\begin{array}{c}\text { Consumo médio de ração } \\
\text { (g/100g de peso } \\
\text { corpóreo/dia) }\end{array}$ \\
\hline OM & 70 & $229,93 \pm 1,5$ & $299,47 \pm 2,1$ & $10,30 \pm 0,2$ \\
\hline $\mathbf{F R}$ & 71 & $230,38 \pm 1,7$ & $300,24 \pm 2,5$ & $10,42 \pm 0,1$ \\
\hline \multicolumn{5}{|c|}{ * Resultados apresentados em média \pm erro padräo } \\
\hline \multicolumn{5}{|c|}{$\mathrm{n}=$ número de animais } \\
\hline \multicolumn{5}{|c|}{$\mathrm{OM}=$ óleo de milho (grupo controle) } \\
\hline \multicolumn{5}{|c|}{$F R=$ farnesol } \\
\hline
\end{tabular}

Assim, é possível se verificar que o peso inicial dos dois grupos foi bastante semelhante, o que indica que a distribuição dos animais foi realizada de forma adequada e aleatória.

Além disso, não foram observadas diferenças estatisticamente significantes $(p>0,05)$ entre os grupos OM (controle) e FR com relação ao peso corpóreo final, consumo médio de ração, bem como em relação ao padrão de crescimento (Figura 6) e consumo de ração (Figura 7) ao longo das 2 semanas de experimento. Da mesma forma, pode-se notar que em todos os momentos de sacrifício os valores referentes ao peso absoluto e relativo do fígado dos animais submetidos ao protocolo experimental (Tabela 3) não apresentaram diferenças significativas $(p>0,05)$ Dessa forma, esses dados 
indicam que na dose utilizada $(25 \mathrm{mg} / 100 \mathrm{~g}$ de peso corporal durante 2 semanas consecutivas) o FR não apresentou toxicidade aparente.

TABELA 3*: Pesos absoluto e relativo do fígado no momento do sacrifício dos animais tratados com OM ou FR durante duas semanas consecutivas e submetidos à HP.

\begin{tabular}{|c|c|c|c|c|}
\hline Grupo & $\begin{array}{l}\text { Momento do } \\
\text { sacrifício após a } \\
\text { hepatectomia } \\
\text { parcial }\end{array}$ & n & $\begin{array}{l}\text { Peso absoluto } \\
\text { do fígado }(\mathrm{g}) \text { por } \\
\text { ocasião do } \\
\text { sacrifício }\end{array}$ & $\begin{array}{l}\text { Peso relativo do } \\
\text { fígado ( } / 100 \mathrm{~g} \\
\text { de peso } \\
\text { corpóreo) }\end{array}$ \\
\hline OM & Oh & 6 & $3,66 \pm 0,2$ & $1,19 \pm 0,1$ \\
\hline FR & Oh & 9 & $3,72 \pm 0,2$ & $1,18 \pm 0,1$ \\
\hline OM & $30 \mathrm{~min}$ & 7 & $3,45 \pm 0,1$ & $1,15 \pm 0,1$ \\
\hline FR & $30 \mathrm{~min}$ & 8 & $3,42 \pm 0,2$ & $1,15 \pm 0,1$ \\
\hline OM & $2 \mathrm{~h}$ & 8 & $3,30 \pm 0,1$ & $1,10 \pm 0,0$ \\
\hline FR & $2 \mathrm{~h}$ & 9 & $3,78 \pm 0,1$ & $1,28 \pm 0,1$ \\
\hline OM & $4 \mathrm{~h}$ & 7 & $3,34 \pm 0,2$ & $1,1 \pm 0,1$ \\
\hline FR & $4 \mathrm{~h}$ & 9 & $3,64 \pm 0,1$ & $1,19 \pm 0,0$ \\
\hline OM & $8 \mathrm{~h}$ & 8 & $3,75 \pm 0,1$ & $1,22 \pm 0,0$ \\
\hline FR & $8 \mathrm{~h}$ & 8 & $3,94 \pm 0,1$ & $1,32 \pm 0,1$ \\
\hline OM & $12 \mathrm{~h}$ & 6 & $3,84 \pm 0,2$ & $1,28 \pm 0,1$ \\
\hline FR & $12 \mathrm{~h}$ & 6 & $4,03 \pm 0,3$ & $1,38 \pm 0,1$ \\
\hline OM & $18 \mathrm{~h}$ & 8 & $4,11 \pm 0,1$ & $1,41 \pm 0,1$ \\
\hline FR & $18 \mathrm{~h}$ & 8 & $4,38 \pm 0,2$ & $1,46 \pm 0,0$ \\
\hline OM & $24 \mathrm{~h}$ & 8 & $4,29 \pm 0,2$ & $1,45 \pm 0,1$ \\
\hline FR & $24 \mathrm{~h}$ & 9 & $4,38 \pm 0,2$ & $1,47 \pm 0,1$ \\
\hline \multicolumn{5}{|c|}{$\begin{array}{l}\text { * Resultados apresentados em média } \pm \text { erro padräo } \\
n=\text { número de animais } \\
\text { OM = óleo de milho (grupo controle) } \\
\text { FR = farnesol }\end{array}$} \\
\hline
\end{tabular}



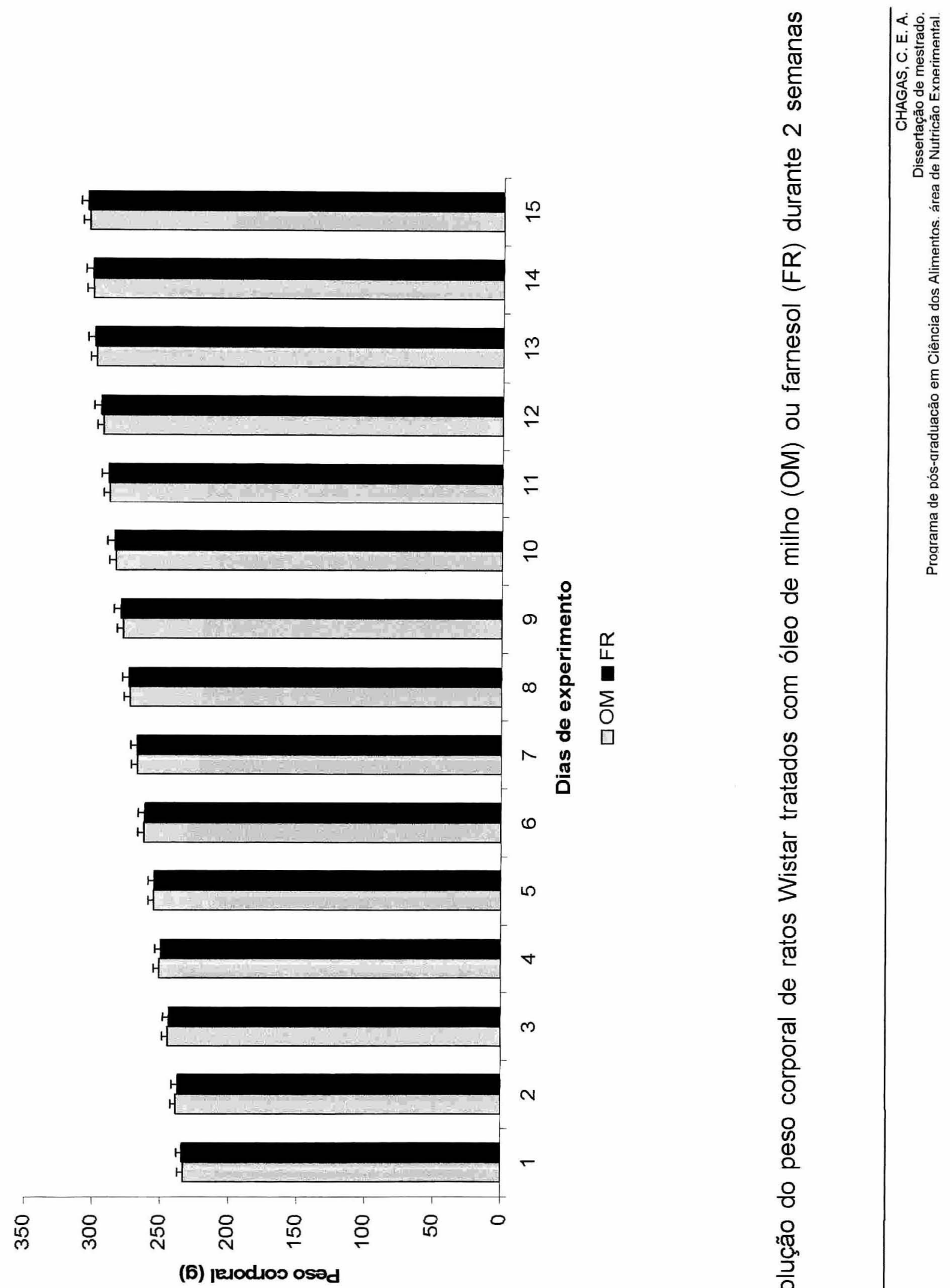


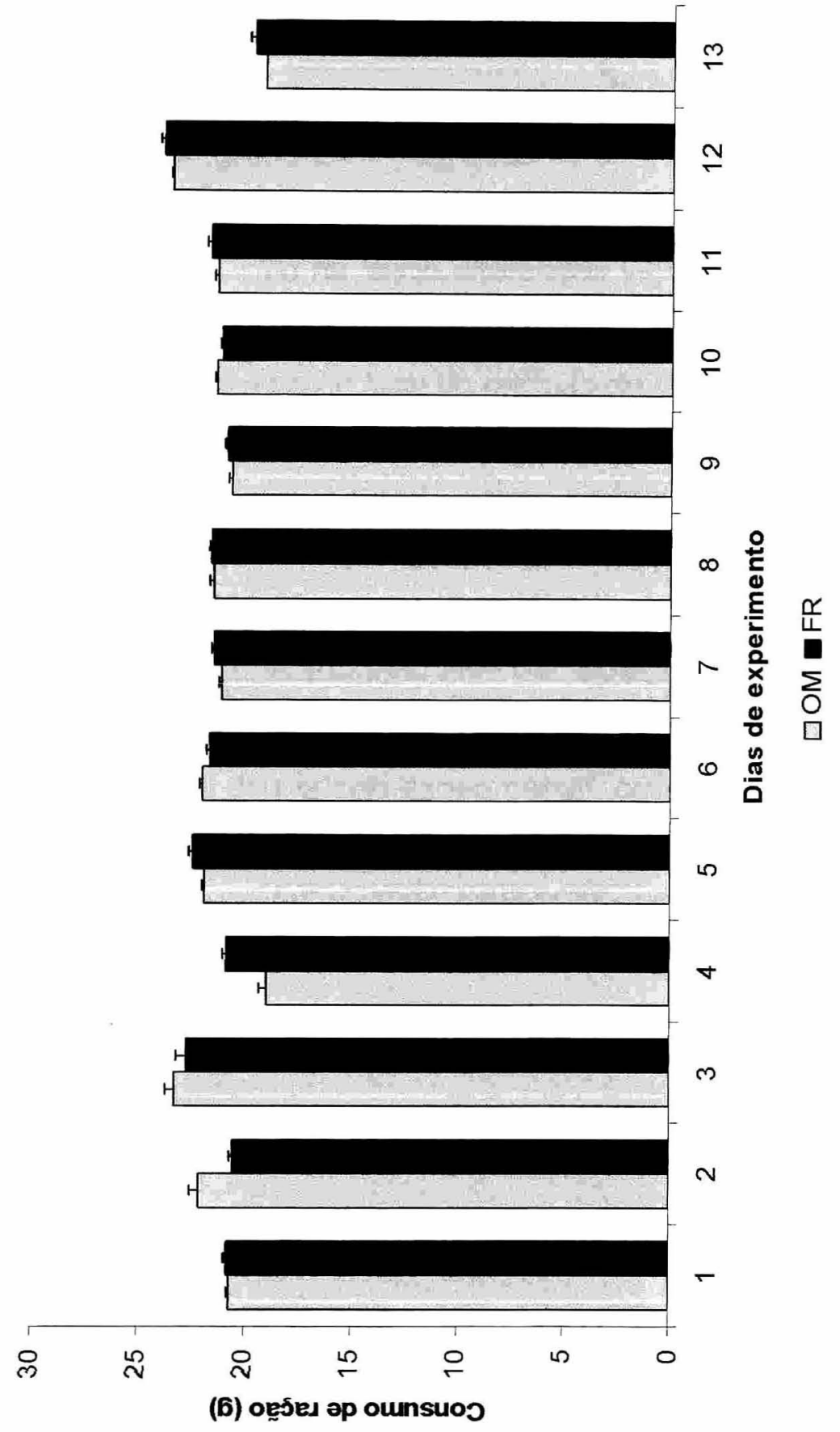

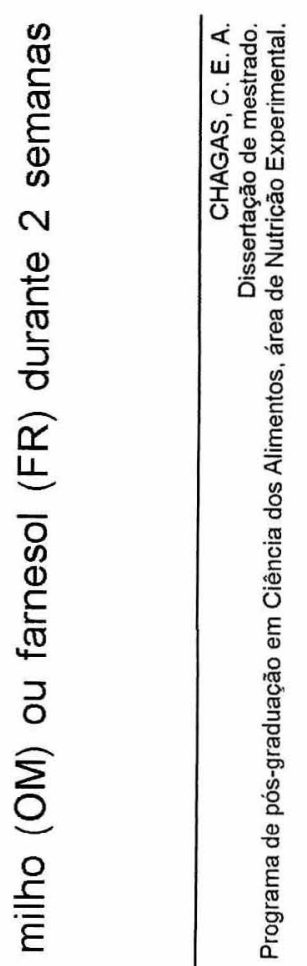




\subsection{Avaliação da proliferação celular hepática}

Para se avaliar a proliferação celular hepática foi realizada a marcação imunoistoquímica para o Antígeno Nuclear de Proliferação Celular (PCNA, do inglês Proliferating Cell Nuclear Antigen) de cortes histológicos dos animais submetidos ao protocolo experimental.

Assim, observando-se os resultados (Figura 8) referentes aos animais tratados com OM (grupo controle), observa-se que nos momentos de sacrifício 0 h, 30 min., 2 h e 4 h após a HP, os valores de proliferação celular hepática foram semelhantes, não havendo diferenças significativas $(p>0,05)$ entre eles. Posteriormente, a partir de $4 \mathrm{~h}$, a taxa de proliferação começou a aumentar atingindo o valor máximo ao final do período de experimentação.

Já os animais tratados com 0 isoprenóide, apresentaram valores semelhantes aos animais controle desde o início do experimento, no momento $0 \mathrm{~h}$, até o momento $4 \mathrm{~h}$, não havendo diferenças significativas $(p>0,05)$ entre os dois grupos experimentais. Da mesma forma, do momento $4 \mathrm{~h}$ até $18 \mathrm{~h}$ após a cirurgia, animais tratados com FR apresentaram, semelhantemente ao grupo tratado com $\mathrm{OM}(p>0,05)$, um aumento da taxa de proliferação. Entretanto, ao final do período experimental, ou seja, $24 \mathrm{~h}$ após a HP, animais tratados com FR apresentaram taxa de proliferação celular hepática inferior $(p<0,05)$ aquela do grupo controle, tratado apenas com OM. 

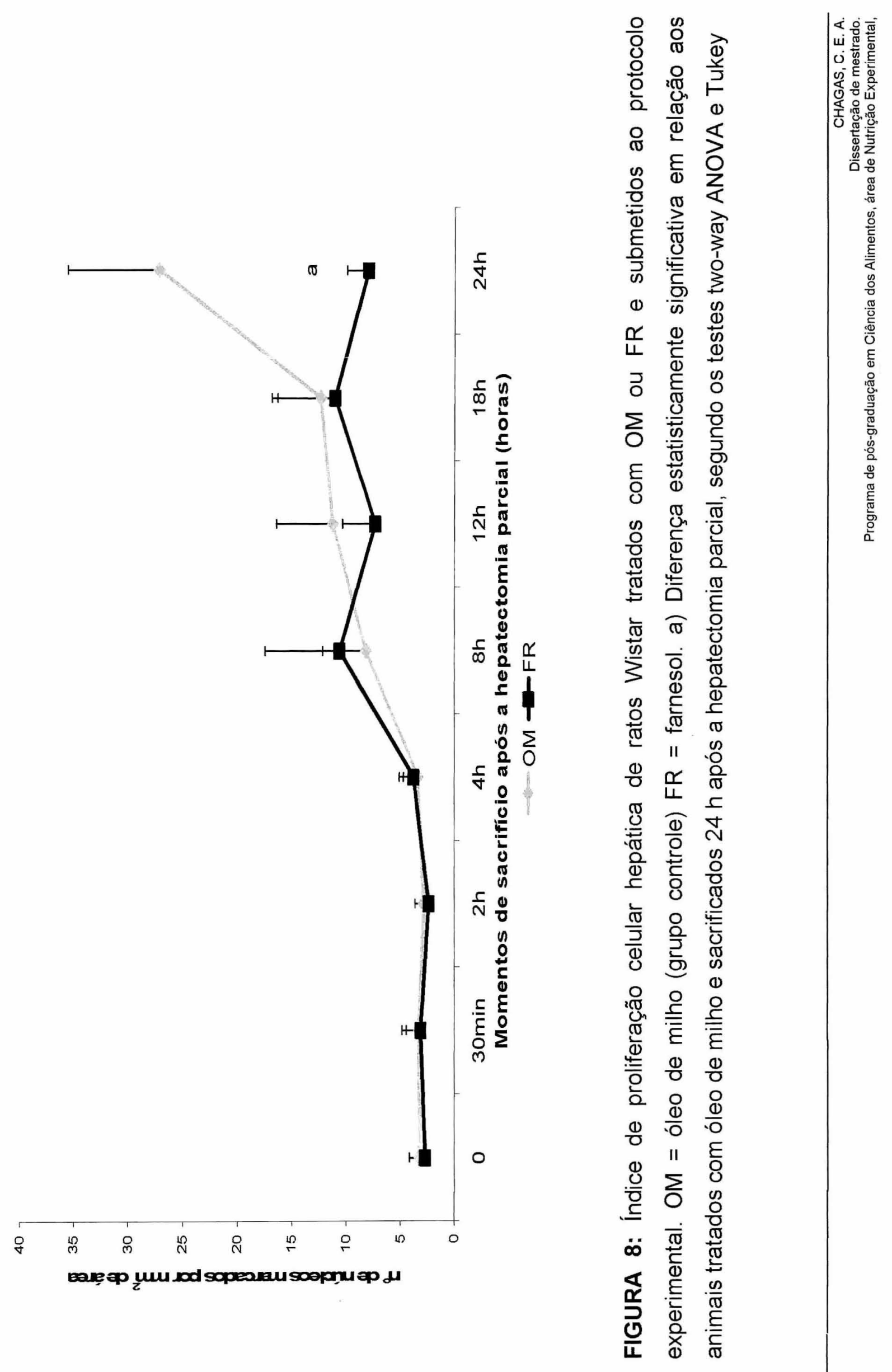


\subsection{Avaliação da apoptose hepática}

A Figura 9 mostra os valores referentes ao número de corpúsculos apoptóticos (CA's) hepáticos de ratos Wistar tratados com OM (grupo controle) ou FR e submetidos a HP.

Ao analisarmos os valores referentes ao número de CA's apresentados pelo grupo OM durante todo o período experimental, observa-se um valor maior nos animais que foram sacrificados $2 \mathrm{~h}$ após a HP, embora não haja diferença em relação aos animais sacrificados nos momentos anteriores (Oh e $30 \mathrm{~min}$ ). Na seqüência, observa-se no momento $4 \mathrm{~h}$ uma redução para um valor semelhante ao encontrado no início do período de experimentação, ou seja, 0 h. A partir dai, o número de CA's nos momentos seguintes manteve-se praticamente constante não havendo variações significativas $(p>0,05)$ até o fim do período de experimentação.

Em contrapartida, os animais tratados com FR, apresentaram em 30mim valor cerca de $1400 \%$ maior $(p<0,05)$ do que o valor encontrado no momento inicial do experimento, ou seja, $0 \mathrm{~h}$. Ainda com relação ao momento $30 \mathrm{~min}$, o valor apresentado no grupo FR, foi cerca de $500 \%$ maior $(p<0,05)$ do que o valor observado no grupo controle (grupo OM). Além disso, quando comparado com animais tratados com OM, observa-se no momento $2 \mathrm{~h}$ uma sugestão de maior número de CA's no grupo tratado com FR. Posteriormente, no momento $4 \mathrm{~h}$, houve uma diminuição no número de $\mathrm{CA}^{\prime} \mathrm{s}(\mathrm{p}<0,05)$ o qual se manteve sem grandes alterações até o momento $8 \mathrm{~h}$. Já em $12 \mathrm{~h}$, houve um aumento no número de CA's de cerca de $400 \%$ em relação a $8 \mathrm{~h}$, embora não significativo estatisticamente ( $p>0,05)$. Ainda em $12 \mathrm{~h}$, quando comparado ao grupo controle, observa-se novamente sugestão de maior número de CA's nos animais tratados com o isoprenóide. Posteriormente, no momento $18 \mathrm{~h}$, o número de CA's volta a reduzir $(p<0,05)$ em relação às $12 \mathrm{~h}$ e se mantêm estável e semelhante ao grupo OM até o final do experimento.

\section{Exemplos dos CA observados encontram-se apresentados na Figura}

10. 


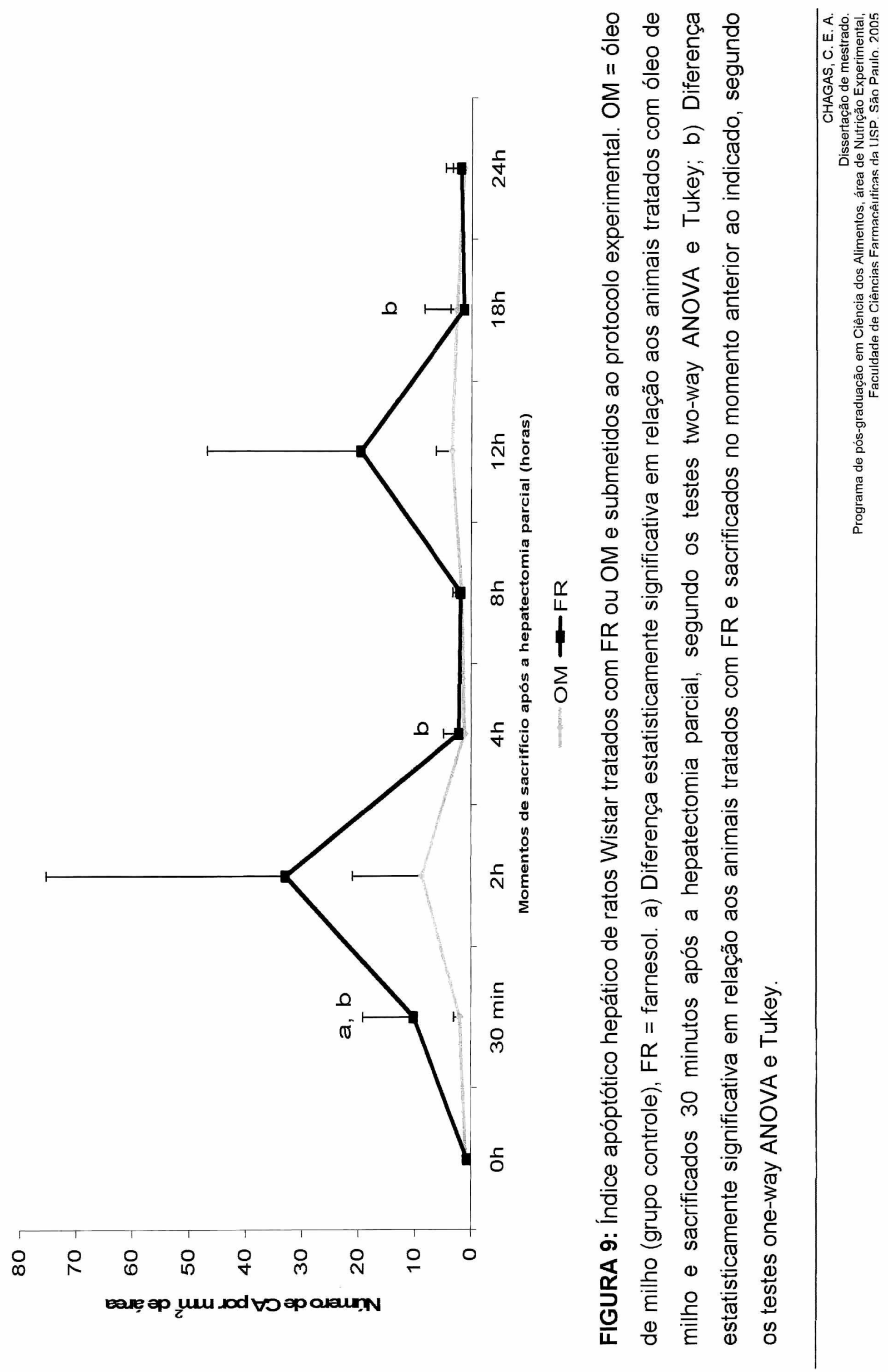




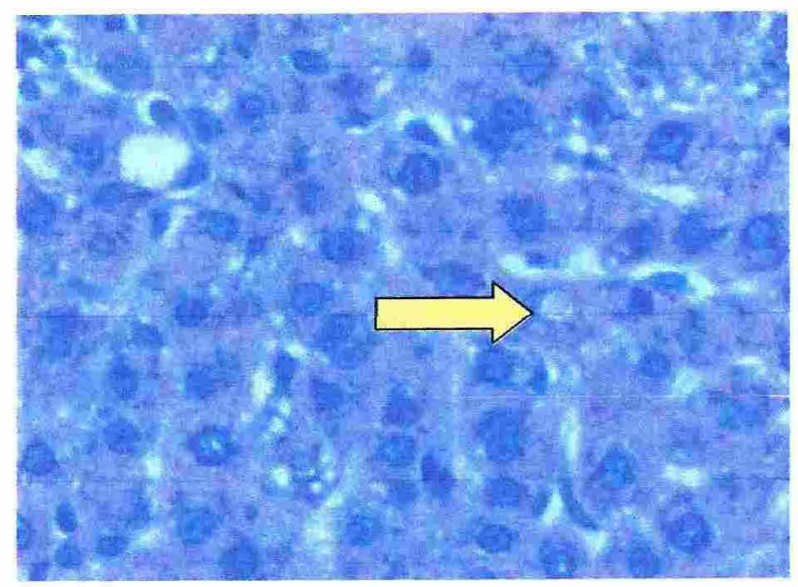

A

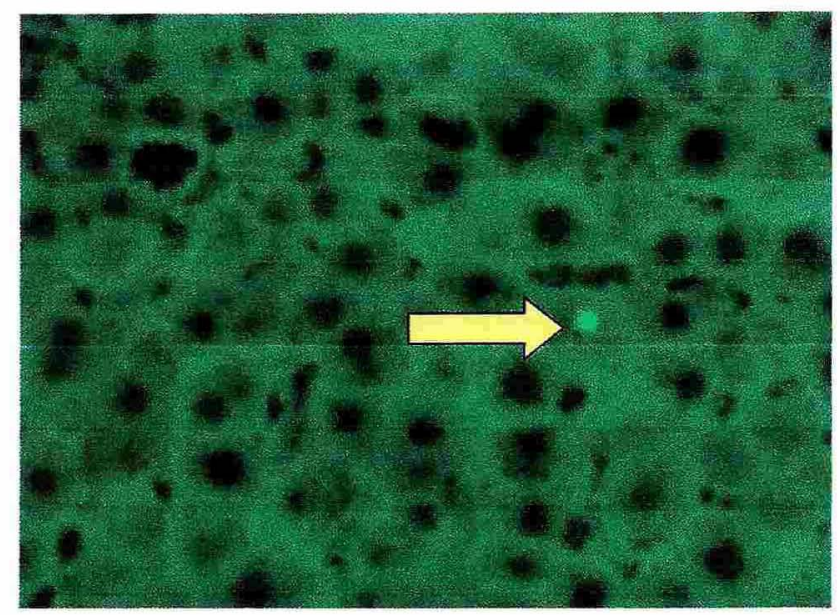

B

FIGURA 10: Digitalização de corte histológico de fígado de rato Wistar tratado com farnesol (grupo FR) durante 2 semanas consecutivas e sacrificado 30 minutos após a hepatectomia parcial. A) Visualização utilizando luz normal. Verificar a presença de corpúsculo apoptótico (seta). Coloração com H\&E. Objetiva de 40x; B) Visualização utilizando microscópio de fluorescência com comprimento de onda entre 450 e $490 \mathrm{~nm}$. Verificar a presença de corpúsculo apoptótico fluorescente (seta). Coloração com H\&E. Objetiva de 40x. 


\subsection{Avaliação da expressão hepática de p65}

Para a avaliação da expressão hepática de p65 dos animais submetidos ao protocolo experimental, foram realizados 6 "imunoblots", cada um dos quais com amostras de proteínas totais de animais tratados com OM e FR e sacrificados $0 \mathrm{~h}, 30 \mathrm{~min}, 2 \mathrm{~h}$ e $4 \mathrm{~h}$ após a HP. A Figura 11 ilustra o resultado de 1 dos 6 "imunoblots" realizados, em que se observa a banda de interesse com $65 \mathrm{KDa}$, referente à p65.

Assim, observa-se que animais tratados com OM (grupo controle) apresentaram maior taxa de expressão de p65 30 min após a HP, sendo essa $50 \%$ maior do que a encontrada em $0 \mathrm{~h}(\mathrm{p}>0,05)$. No momento 2 horas, observa-se uma redução de $25 \%$ na expressão de p65 em relação à encontrada em 30 min ( $p>0,05)$. Já $4 \mathrm{~h}$ após a cirurgia, o valor volta a se reduzir, sendo cerca de $30 \%$ menor do que em 2 h, embora a diferença não tenha atingido significância estatística.

Já os animais tratados com FR durante duas semanas consecutivas, apresentaram expressão $17 \%$ menor $(p>0,05)$ do que o grupo controle logo ao início do período experimental, ou seja, em $0 \mathrm{~h}$. No momento $30 \mathrm{~min}$, animais tratados com o isoprenóide apresentaram expressão de p65 40\% menor $(p>0,05)$ do que o grupo controle. Em relação aos outros momentos de sacrifício, animais tratados com FR continuaram a apresentar valores inferiores aos apresentados pelo grupo controle e semelhantes aos observados em $0 \mathrm{~h}$ e 30 min após a HP, embora essas diferenças não alcançassem significância estatística. 


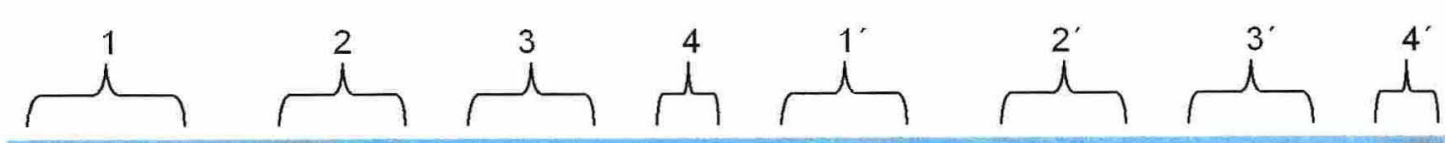

$65 \mathrm{KDa}$

A

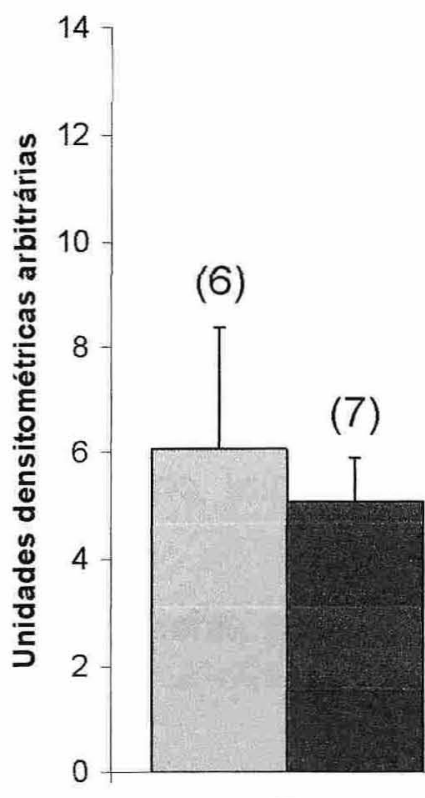

Oh
(7)

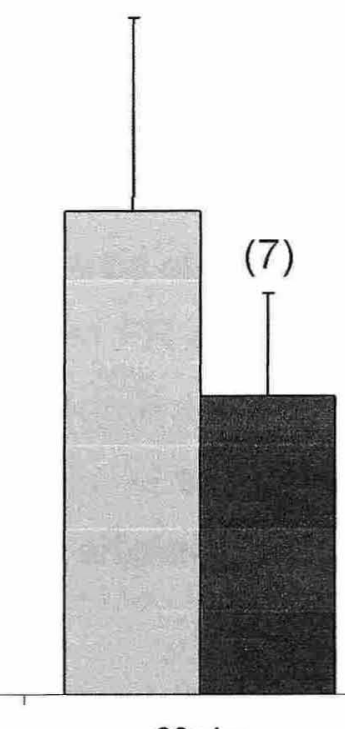

$30 \mathrm{mim}$

(7)
(7)

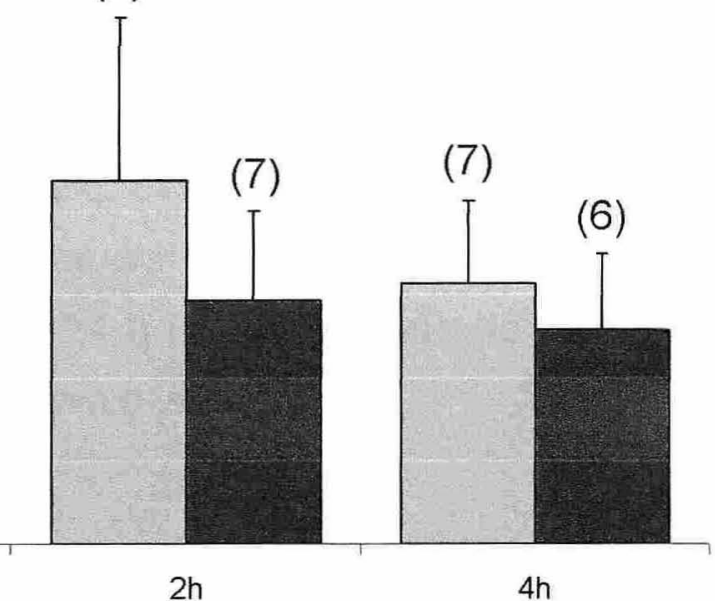

$2 \mathrm{~h}$

$4 h$

Momentos de sacrifício após a hepatectomia parcial

$\square \mathrm{OM}$ 圆FR

B

FIGURA 11: Expressão hepática de p65 de ratos Wistar tratados com OM (grupo controle) ou FR e submetidos ao protocolo experimental. OM, óleo de milho. FR, farnesol. A) Digitalização ilustrativa de um "blot". 1, animais tratados com OM e sacrificados no momento $0 \mathrm{~h} ; 2$, animais tratados com $\mathrm{OM}$ e sacrificados $30 \mathrm{~min}$ após a hepatectomia parcial (HP); 3 , animais tratados com OM e sacrificados $2 \mathrm{~h}$ após a HP; 4, animal tratado com OM e sacrificado $4 \mathrm{~h}$ após a HP; 1', animais tratados com FR e sacrificados no momento Oh; 2', animais tratados com FR e sacrificados 30 min após a HP; $3^{\prime}$, animais tratados com FR e sacrificados $2 \mathrm{~h}$ após a HP; 4', animal tratado com FR e sacrificado 4h após a HP. B) Resultado referente a média de 6 "blots". Os valores entre parênteses sobre as barras indicam o número total de animais analisados 


\subsection{Avaliação da expressão hepática de ciclina D1}

Para a avaliação da expressão hepática de ciclina D1 dos animais submetidos ao protocolo experimental, foram realizados 6 "imunoblots", cada um dos quais com amostras de proteínas totais de animais tratados com OM e FR e sacrificados 0 h, 8 h, 12 h, 18 h e 24 h após a HP. A Figura 12 ilustra resultado de 1 dos 6 "imunoblots" realizados, em que se observa a banda de interesse com $35 \mathrm{KDa}$, referente à ciclina D1.

Assim, o grupo tratado com OM apresentou menor expressão de ciclina D1 ao início do período de experimentação. No entanto, após o momento $12 \mathrm{~h}$, a expressão começa a aumentar até atingir o máximo $24 \mathrm{~h}$ após a HP com valores $131 \%$ maiores do que os observados em $0 \mathrm{~h}$.

Já o grupo tratado com FR apresentou expressão semelhante ao grupo controle do início do experimento até o momento $18 \mathrm{~h}$. Todavia, quando comparado ao grupo controle, observa-se em $24 \mathrm{~h}$ uma expressão de ciclina D1 $50 \%$ menor $(p>0,05)$ nos animais tratados com o isoprenóide. 


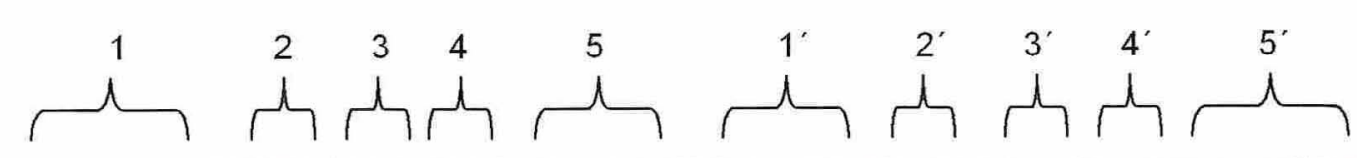

$35 \mathrm{KDa}$

A

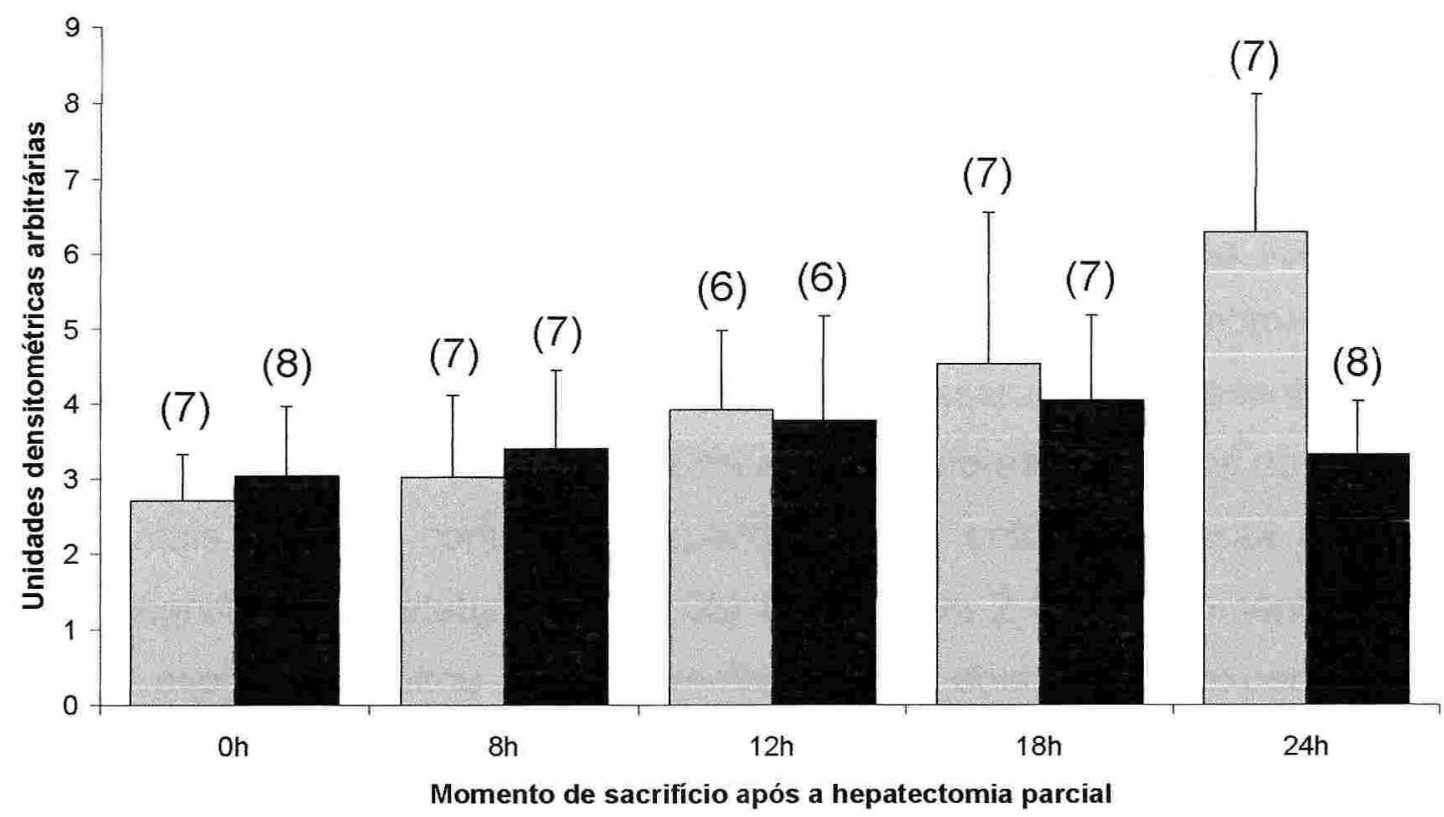

$\square O M=F R$

B

FIGURA 12: Expressão hepática de ciclina D1 de ratos Wistar tratados com OM (grupo controle) ou FR e submetidos ao protocolo experimental. OM, óleo de milho. FR, farnesol. A) Digitalização ilustrativa de um "blot". 1, animais tratados com OM e sacrificados no momento oh; 2, animal tratado com OM e sacrificados $8 \mathrm{~h}$ após a hepatectomia parcial (HP); 3, animal tratado com OM e sacrificados $12 \mathrm{~h}$ após a HP; 4, animal tratado com OM e sacrificado 18h após a $\mathrm{HP}$; 5, animais tratados com OM e sacrificados $24 \mathrm{~h}$ após a HP; 1', animais tratados com FR e sacrificados no momento Oh; 2', animal tratado com FR e sacrificados 8h após a HP; 3', animal tratado com FR e sacrificado 12h após a HP; 4', animal tratado com FR e sacrificado 18h após a HP; 5', animais tratados com FR e sacrificados 24h após a HP. B) Resultado referente a média de 6 "blots". Os valores entre parênteses sobre as barras indicam o número total de animais analisados. 
4.6 Avaliação da expressão hepática do gene que codifica para a enzima HMG-CoA redutase

Para a avaliação da expressão hepática do gene que codifica para a enzima HMG-CoA redutase dos animais submetidos ao protocolo experimental, o RNA total extraído foi submetido à análise pela técnica de "Dot blot".

Assim, como pode ser observado na Figura 13, a taxa de expressão para esse gene nos animais tratados com OM oscilou entre os diferentes momentos de sacrifício, atingindo a expressão máxima 24 h após a HP, com valores $58 \%$ maiores do que os observados em $0 \mathrm{~h}$.

Já o grupo tratado com $\mathrm{FR}$, apresentou taxa de expressão semelhante ao grupo controle nos momentos $0 \mathrm{~h}$ e $30 \mathrm{~min}$. A partir daí, nos momentos, $2 \mathrm{~h}$ e $4 \mathrm{~h}$, animais tratados com 0 isoprenóide passaram a apresentar maior expressão deste gene com valores $23 \%$ e $17 \%$ maiores do que os observados nos animais tratados com OM, respectivamente; entretanto, essa diferença atingiu significância estatística $(p<0,05)$ apenas em 2 h. No momento $8 \mathrm{~h}$, a taxa de expressão voltou a ser semelhante nos dois grupos experimentais. Posteriormente, em $12 \mathrm{~h}$, animais tratados com FR apresentaram novamente expressão do gene que codifica para a enzima HMG-CoA redutase maior $(p<0,05)$ do que os animais tratados com OM. Já nos momentos subseqüentes, $18 \mathrm{~h}$ e $24 \mathrm{~h}$, animais tratados com o isoprenóide apresentaram taxa de expressão $15 \%$ e $12 \%$ menor do que os animais pertencentes ao grupo controle, respectivamente, todavia, sem essas diferenças atingirem significância estatística. 
FIGURA 13: Avaliação da expressão hepática do gene para HMG-CoA redutase. A) Radiografia da membrana. B) Membrana corada com azul de metileno. C) Figura com a média de 4 (quatro) animais analisados em cada um dos diferentes momentos de sacrifício. OM, óleo de milho; FR, farnesol. Os números indicam o momento do sacrifício após a hepatectomina parcial (HP): $1,0 \mathrm{~h} ; 2,30 \mathrm{~min} ; 3,2 \mathrm{~h} ; 4,4 \mathrm{~h} ; 5,8 \mathrm{~h} ; 6,12 \mathrm{~h} ; 7,18 \mathrm{~h}$ e $8,24 \mathrm{~h}$. 

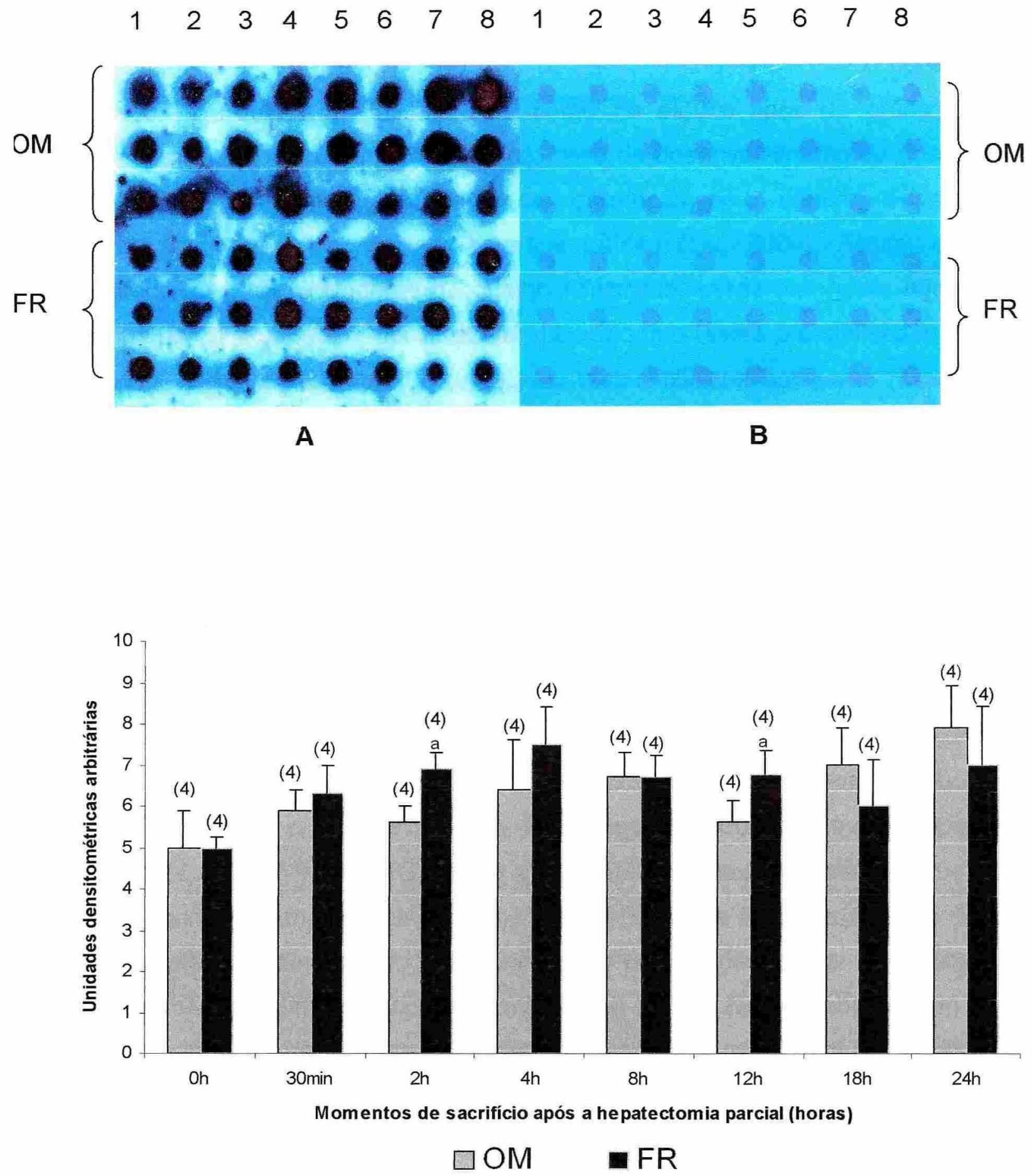

C 


\section{DISCUSSÂO}

Atualmente é grande o número de estudos sugerindo que o consumo elevado de frutas e hortaliças, bem como de alguns tipos de grãos está fortemente associado a uma redução do risco de desenvolvimento de doenças crônicas não transmissíveis como as cardíacas e o câncer, principais responsáveis pelas mortes em diversos países (Liu, 2004). Assim, como acontece no desenvolvimento de qualquer fármaco, esses potenciais agentes quimiopreventivos devem ser também submetidos a testes pré-clínicos in vitro e in vivo para, então, serem conduzidos testes clínicos em seres humanos (Greenwald, 2002). Nos estudos em animais, além de se avaliar o potencial quimiopreventivo das substâncias, busca-se também mecanismos de ação anticarcinogênica envolvidos (Sporn e Suh, 2002).

Dessa forma, alimentos, nutrientes e outros compostos bioativos (CBA's) neles presentes, foram testados em diversos modelos experimentais de câncer. Assim, a partir dos resultados desses estudos, conclui-se que grande parte dessas substâncias atua na proliferação celular e/ou apoptose (Liu, 2004). Nesse sentido, em estudos desenvolvidos previamente pelo nosso grupo, observou-se que diversos derivados isoprênicos como, por exemplo, o betacaroteno (Moreno et al., 1991; 1995a; Fonseca et al., 2005), luteína e licopeno (Todelo et al., 2002), FR e GR (Ong et al., 2005) e, mais recentemente betaionona, geranilgeraniol (Espíndola et al., 2005), vitamina A, ácido retinoico 9cis e todo trans (Fonseca et al., 2005) inibiram a proliferação celular em animais submetidos ao modelo de hepatocarcinogênese do RH. Além disso, também se observou indução de apoptose por parte do monoterpeno GR em ratos Wistar submetidos ao mesmo modelo de hepatocarcinogênese (Ong et al., 2005).

Apesar dessas evidências, pouco se sabe a respeito do papel dessas substâncias em vias de sinalização celular envolvidas com os processos de proliferação celular e apoptose.

Recentemente, Ong et al. (2005) observaram que o tratamento de ratos Wistar com FR durante as etapas iniciais da hepatocarcinogênese resultou em ação quimiopreventiva. Além disso, os autores apontam como mecanismo associado a essa ação, uma potente inibição da proliferação celular por parte do isoprenóide. Dessa forma, o presente estudo teve como objetivo avaliar o 
efeito do tratamento com FR em ratos Wistar submetidos à HP, modelo clássico para estudo da proliferação celular hepática in vivo. Assim, com o intuito de comparação com o estudo desenvolvido previamente por Ong et al. (2005), foi mantida a dose de $25 \mathrm{mg} / 100 \mathrm{~g}$ de peso corporal/dia.

Descreve-se que no interior da célula o FR é oxidado a farnesal devido à ação de álcool desidrogenases presentes no citoplasma, peroxissomos e mitocôndrias (Westfall et al., 1997). Os aldeídos formados são oxidados a ácidos dicarboxílicos e excretados pela urina (Vaidya et al., 1998). Portanto, devido à reduzida meia-vida celular do FR (Elson et al., 1999; Flach et al., 2000; McAnnaly et al., 2003), decidiu-se administrar diariamente o isoprenóide aos animais submetidos ao protocolo experimental.

Inicialmente, é importante aqui ressaltar que o tratamento com FR não alterou o consumo de ração nem o crescimento dos animais (Figuras 6 e 7). Assim, os diferentes efeitos constatados por parte do FR no presente estudo, e discutidos a seguir, não devem estar relacionados a um menor consumo energético. Da mesma forma, também não ocorreram diferenças significativas entre os grupos FR e OM (controle) em relação ao peso absoluto e relativo do fígado (Tabela 3), o que parece excluir a possibilidade de toxicidade hepática por parte do isoprenóide.

A proliferação celular apresenta papel importante tanto no desenvolvimento, como na prevenção do câncer (Mori et al., 2001). Assim, dentre os diversos mecanismos de ação que se descreve para substâncias quimiopreventivas, a inibição da proliferação celular constitui, certamente, um dos principais exemplos (Greenwald, 2002). Nesse sentido, com o objetivo de verificar a ação do FR nesse processo, avaliou-se o índice de marcação para PCNA em núcleo de hepatócitos nas amostras de fígado dos animais submetidos à HP.

Para a avaliação da proliferação celular existem diversos métodos descritos na literatura. Dessa forma, pode-se utilizar para tal propósito, por exemplo, a expressão de alguns genes e análises imunoistoquímicas (Assy e Ninuk, 1997). Para a avaliação da proliferação celular, optou-se no presente estudo pela reação imunoistoquímica para PCNA, uma proteína essencial à síntese do DNA e que apresenta uma boa correlação com outros métodos 
estabelecidos para esta finalidade como, por exemplo, a atividade de timidina quinase (Assy e Ninuk, 1997).

Dessa forma, como se observa na Figura 8, o tratamento com FR durante duas semanas consecutivas em ratos Wistar submetidos à HP, foi capaz de inibir a proliferação celular $(p<0,05)$ ao final do período de experimentação, ou seja, 24 h após a cirurgia.

Diversos outros trabalhos mostram que isoprenóides, dentre eles o FR, inibem a proliferação de diversas linhagens de células tumorais (Shoff et al., 1991; Yu et al., 1995; Burke et al., 1997; He et al., 1997; Mo et al., 2000), estando essa inibição relacionada com o bloqueio da transição $\mathrm{G}_{1}-\mathrm{S}$ do ciclo celular (Mo e Elson, 1999; Mo et al., 2000; Tatman e Mo, 2002).

De uma forma geral, a inibição da proliferação celular por isoprenóides, relaciona-se à capacidade destes de inibir a enzima HMGCoA redutase, limitando, assim, modificações pós-tradução como a farnesilação e a geranilgeranilização de proteínas fundamentais para o ciclo celular como, por exemplo, a ras (Moreno et al., 1995b; Elson et al., 1999; Mo et al., 2000; Rao et al., 2002).

A proteína ras é uma proteína $\mathrm{G}$ monomérica (do inglês small G protein), que quando ativada por mitogênicos extracelulares tem importante papel no processo de proliferação celular. Assim, estudos mostraram que essa proteína está envolvida com a expressão de ciclina D1 e CDKI's durante a progressão do ciclo celular (Takuwa e Takuwa, 2001; Stacey e Kazlauskas, 2002).

Neste sentido, Mo e Elson (2004), em uma recente revisão a respeito do papel de derivados isoprênicos como agentes quimioterápicos e quimiopreventivos, descrevem que a lovastatina e o álcool perilílico atuam em proteínas do ciclo celular necessárias à transição $G_{1}-S$, como a ciclina $D 1$ e a proteina retinoblastoma $(\mathrm{pRb})$. Isso ocorreria devido ao bloqueio da modificação pós-tradução da proteína ras. Com isso, existiria um acúmulo de p2 $1^{\text {WAF/CIP1 }}$, que seria responsável pela inibição do complexo ciclina D1/cdk4-6, com conseqüente manutenção do estado hipofosforilado de $\mathrm{pRb}$.

Da mesma forma, observou-se que o antranilato de farnesila, um isoprenóide misto, foi capaz de inibir a proliferação de células de melanoma B16 implantadas em camundongos. Nesse caso, esse tratamento resultou também em redução da concentração de colesterol plasmático total. Portanto, 
com base na premissa de que uma redução da concentração plasmática de colesterol de animais alimentados com rações isentas de colesterol seriam reflexo de diferenças na atividade de HMG-CoA redutase (Espíndola et al., 2005), os autores do estudo (Mo et al., 2000) sugeriram que as ações antitumorais do antranilato de farnesila estariam relacionadas à inibição desta enzima promovida pelo grupamento farnesila do éster em questão.

Diversos isoprenóides, tais como o FR (Corell et al., 1994; Meigs et al., 1997; Shearer e Hampton, 2005), GR (Yu et al., 1994), tocotrienóis (Parker et al., 1993), $\beta$-caroteno (Moreno et al., 1995b), $\beta$-ionona (Case et al., 1995), limoneno (Qureshi et al., 1988), mentol (Clegg et al., 1982) e GGO (Sever et al., 2003), têm a capacidade de inibir in vitro e in vivo a enzima HMGCoA redutase por meio de mecanismos pós-transcricionais (Elson et al., 1994; 1995), dentre os quais se destaca o estímulo da degradação da enzima (Parker et al., 1993; Elson et al., 1999; Shearer e Hampton, 2005).

Nesse sentido, Moreno et al. (1995b), verificaram o efeito do tratamento com $\beta$-caroteno em um modelo experimental semelhante ao utilizado no presente estudo, porém utilizando ratos da linhagem F344, na expressão do gene para a enzima HMG-CoA redutase. Assim, os autores observaram que animais controle, tratados somente com óleo de milho, apresentaram dois picos de expressão para esse gene, o primeiro, maior, $8 \mathrm{~h}$ e o segundo, menor, $24 \mathrm{~h}$ após a HP. No entanto, o tratamento com o carotenóide reduziu a expressão deste gene em $50 \%$ e $30 \% 8$ e 24 h após a cirurgia. Uma posterior análise pela técnica de run-off mostrou que tal ação por parte do carotenóide ocorreu devido a modificações pós-transcricionais.

No presente estudo, ao analisarmos os resultados referentes à expressão gênica de HMG-CoA reduatse (Figura 13), animais controles, tratados apenas com óleo de milho, quando sacrificados $24 \mathrm{~h}$ após a cirurgia, apresentaram maior $(p>0,05)$ expressão desse gene quando comparados ao grupo tratados com o isoprenóide, como observado em um estudo prévio (Moreno et al., 1995b). Além disso, animais tratado com FR quando comparado ao grupo controle, apresentaram, curiosamente, maior taxa de expressão $(p<0,05) 2$ e $12 \mathrm{~h}$ após a HP. Coincidentemente, Ong et al. (2005), observaram que animais tratados com FR, porém submetidos ao modelo de 
hepatocarcinogênese do $\mathrm{RH}$, também apresentaram aumento da expressão do gene para HMG-CoA redutase.

Uma possível explicação para esse aumento de expressão, seria o fato de isoprenóides inibirem a proliferação celular independentemente de atuarem na via do mevalonato. Nesse sentido, Duncan et al. (2004) tratando células MCF-7 com GR ou $\beta$-ionona, observaram que apenas o GR inibiu a atividade da enzima HMG-CoA redutase.

Entretanto, o aumento da expressão observado no presente estudo nos animais tratados com FR e sacrificados 2 e $12 \mathrm{~h}$ após a HP, poderia ser devido a uma maior taxa de degradação da enzima HMG-CoA redutase por parte do isoprenóide. Nesse sentido, Shearer e Hampton (2005), observaram recentemente que o FR induziu um aumento da degradação da enzima HMGCoA redutase in vitro, enquanto nenhum efeito foi observado após o tratamento com GR ou outro análogos do FR. Dessa forma, o aumento da expressão do gene para esta enzima observado no presente estudo poderia estar relacionado a um aumento da taxa de degradação da enzima por parte do isoprenóide (Ong et al., 2005).

Outra via importante para proliferação celular é àquela controlada pelo fator nuclear kappa $\mathrm{B}(\mathrm{NF \kappa B})$. Esse fator de transcrição é necessário à regeneração hepática e apresenta elevada atividade nuclear no fígado dos animais cerca de 30 min após a HP (Fausto, 2000). Além disso, alguns autores observaram que camundongos nocaute para p65, um dos componentes de $\mathrm{NF}_{\kappa} \mathrm{B}$, apresentaram complicações embrionárias e degeneração hepática por apoptose, indicando que esse fator de transcrição é necessário à sobrevivência dos hepatócitos (Schrum et al., 2000). Por outro lado, camundongos que não expressam p50 apresentam regeneração hepática normal (Deangelis et al., 2001). Posteriormente, descreveu-se que esse fator de transcrição controla positivamente a expressão de ciclina D1, proteína importante para a transição $\mathrm{G}_{1}-\mathrm{S}$ do ciclo celular (Joice et al., 2001) e bcl-xL, importante para o controle da apoptose (DeAngelis et al., 2005).

Embora seja importante para os processos de proliferação celular e apoptose (Chaisson et al., 2002), existem poucos estudos mostrando a cinética desse fator de transcrição durante a regeneração hepática. 
Nesse sentido, o grupo liderado por Rebecca Taub publicou em 1994 um estudo que mostrou, utilizando a técnica de "western blot", que o p65 é rapidamente translocado para o núcleo, em aproximadamente 30 min após a HP. Além disso, os autores verificaram que cerca de $99 \%$ do total de p65 encontra-se no citoplasma tanto antes quanto após a cirurgia (Cresman et al., 1994). Dessa forma, além da sua ativação, a modulação da expressão desse fator de transcrição também é importante para o controle da proliferação celular.

No presente estudo, animais tratados com FR apresentaram expressão de p65 40\% menor $(p>0,05)$ do que os animais controle 30 min após a HP. Da mesma forma, quando comparado ao grupo OM, o tratamento com o isoprenóide reduziu em 50\% a expressão de ciclina D1 24 h após a cirurgia, embora essa diferença também não tenha atingido significância estatística. Assim, sugere-se que essa menor expressão de p65 observada, implique em uma menor translocação nuclear com conseqüente menor transcrição de genes modulados por NFKB como, por exemplo, aquele para ciclina D1.

Além disso, com base em relatos da literatura (Takuwa e Takuwa, 1997; 2001), sugere-se que as alterações na expressão do gene para HMG-CoA redutase observadas no presente estudo, possam também talvez estar relacionada com a menor expressão hepática de ciclina D1 nos animais tratados com o isoprenóide.

Agentes quimiopreventivos também atuam na carcinogênese induzindo o processo de apoptose (Sun, 2001; Greenwald, 2002). Dessa forma, decidiuse também no presente estudo por avaliar a apoptose hepática nos animais submetidos ao protocolo experimental.

Assim, os resultados referentes à contagem de CA's nos cortes histológicos hepáticos dos animais pertencentes ao grupo FR mostraram que o tratamento com 0 isoprenóide foi capaz de induzir a apoptose. Dessa forma, observou-se 30 min após a HP que animais tratados com FR apresentaram maior número $(p<0,05)$ de $C A^{\prime}$ 's do que os animais tratados com OM. Além disso, vale aqui ressaltar que em comparação ao grupo controle, observa-se tendência de um maior número de CA's nos animais tratados com FR e sacrificados $2 \mathrm{~h}$ e $12 \mathrm{~h}$ após a cirurgia. No entanto, essas diferenças 
curiosamente não atingiram a significância estatística provavelmente devido à grande variabilidade dos valores.

A apoptose, da mesma forma que a proliferação celular, desempenha uma importante função no controle da homeostase hepática, já que uma regeneração anormal pode resultar em falência, cirrose e até câncer hepático (Akcali, et al., 2004).

Células em apoptose exibem uma típica condensação do citoplasma e da cromatina, com subseqüente fragmentação do núcleo e formação dos CA's. Um CA característico consiste de compartimentos nucleares e citoplasmáticos com organelas intactas cercadas pela membrana plasmática (Kren et al., 1996)

Atualmente, existem diversos métodos para a avaliação da apoptose tanto in vitro, como in vivo (Rust e Gores, 2000). Assim, descreve-se que embora o uso de eletroforese em gel de agarose para demonstrar a ocorrência de apoptose pela fragmentação característica do DNA represente método bioquímico interessante e bastante utilizado, este apresenta, por outro lado, limitações que se referem, por exemplo, a sua reduzida sensibilidade para detectar pequenas diferenças quantitativas (Saraste e Pulkki, 2000). Nesse caso, o uso de critérios morfológicos tem sido considerado a forma mais confiável para se evidenciar a apoptose (Wood et al., 1999; Saraste e Pulkki, 2000).

Nesse sentido, descreve-se que células que adentram ao processo de apoptose apresentam características morfológicas específicas que são passíveis de identificação utilizando-se, por exemplo, microscópio de luz de contraste de fase simples (Sgonc e Gruber, 1998). Dentre os diversos métodos existentes para se detectar apoptose em tecidos fixados, a observação de alterações morfológicas consiste em um dos mais utilizados (Riss, 2001), o que permite, por sua vez, que um grande número de células seja estudado (Saraste e Pulkki, 2000). Além disso, no caso específico de tecido hepático corado com hematoxilina e eosina ( $\mathrm{H} \& \mathrm{E})$, essa metodologia específica pode também ser empregada visto que hepatócitos apoptóticos se apresentam como corpúsculos acidofílicos arredondados que se encontram separados das células ao redor podendo, ainda, apresentar núcleo fragmentado (Rust e Gores, 2000). 
Além disso, também é possível se quantificar CA's hepáticos por meio da metodologia descrita por Stinchcombe et al. (1995), que se baseia na observação de que estes apresentam intensa fluorescência da eosina em cortes histológicos de fígado corados com H\&E e submetidos à luz com comprimento de onda entre 450 e $490 \mathrm{~nm}$. De acordo com os autores, a intensa fluorescência dos CA's possibilita que estes sejam identificados mais rapidamente por microscopia de fluorescência em comparação ao uso de luz transmitida normal. Além disso, a utilização dessa metodologia específica permite também localizar pequenos CA's que normalmente não seriam identificados utilizando-se luz normal. Isso, segundo os autores, torna o método em questão cerca de 3 vezes mais sensível do que o convencionalmente utilizado e que emprega luz transmitida normal. Além disso, em caso de dúvida em relação à identidade da estrutura fluorescente, esta pode ainda ser confirmada por critérios morfológicos clássicos (Grasl-Kraupp et al., 1994), alternando-se o sistema para luz normal.

Dessa forma, decidiu-se no presente estudo utilizar essa metodologia para avaliar a apoptose. Nesse sentido, a microscopia de fluorescência mostrou-se bastante adequada para a identificação dos CA's hepáticos. De fato, foi possivel observar corpúsculos fluorescentes de maior e menor tamanho conforme originalmente descrito por Stinchcombe et al. (1995) ao longo da avaliação das lâminas contendo cortes histológicos corados com H\&E dos animais submetidos ao protocolo experimental.

Descreve-se que o FR é um potente indutor da apoptose, preferencialmente em células transformadas (Edward e Ericsson, 1999; Rioja et al., 2000; Wright et al., 2001; Lagace et al., 2002), ou seja, naquelas cujo controle transcricional da enzima HMG-CoA redutase encontra-se alterado. Nesse sentido, descreve-se também que inibidores da enzima HMG-CoA redutase, como as vastatinas, induzem apoptose em diversas linhagens celulares (Garcia-Román, 2001; Park et al., 2001; Blanco-Colio et al., 2002; 2003; Shellman et al., 2005).

Assim, como descrito anteriormente, animais tratados com FR e sacrificados $2 \mathrm{~h}$ e $12 \mathrm{~h}$ após a HP, apresentaram aumento da expressão do gene para HMG-CoA redutase. Curiosamente, nestes momentos de sacrifício, quando comparados ao grupo controle, animais tratados com FR, 
apresentaram número de CA's 278\% e 478\% maiores ( $p>0,05)$ em 2 h e 12 h, respectivamente.

Outro mecanismo importante para o processo de apoptose é controlado por membros da família Bcl-2. Essas proteínas controlam a liberação do citocromo c da mitocôndria. Descreve-se que os membros anti-apoptóticos inibem a apoptose devido ao antagonismo com os membros pró-apoptóticos dessa família (Ashe e Berry, 2003).

Observações a respeito do potencial do FR em induzir a apoptose in vivo foram descritas por Burke et al. (2002). Nesse estudo, os autores descreveram que o FR induziu a apoptose em hamsters submetidos a modelo de carcinogênese química de pâncreas. Como mecanismo associado a essa indução, o estudo mostra, ainda, alterações na família $\mathrm{Bcl}-2$, com aumento de Bak, pró-apoptótica, e diminuição de Bcl-xL, anti-apoptótica. Da mesma forma, na indução de apoptose observada após o tratamento de células com vastatinas (Garcia-Román, 2001, Blonco-Colio, 2002; 2003), também ocorreu alterações na taxa de expressão de genes da família bcl-2 como bcl-xL, bcl-2 e bax. Dessa forma, sugere-se que as alterações na taxa de expressão do gene para HMG-CoA redutase observadas no presente estudo possam estar relacionadas com a indução de apoptose por parte do isoprenóide.

Descreve-se que a inibição de NFKB poderia estar envolvida com a indução de apoptose em diversos modelos experimentais in vitro (Plumpe el al.,2000; Clarke et al., 2005; Hsu et al., 2005). No entanto, com relação ao fígado, estudos utilizando diversos modelos experimentais não apresentam um consenso em relação à inibição deste fator de transcrição e indução da apoptose (limuro ei al.,1998; Chaisson et al. 2002; Bird et al., 2003; Luedde et al., 2005; Espíndola et al., 2005; DeAngelis et al., 2005).

Nesse sentido, nosso grupo analisou recentemente o efeito da $\beta$-ionona e do GGO em ratos Wistar submetidos ao modelo de hepatocarcinogênese do $\mathrm{RH}$. Embora o tratamento com os dois isoprenóides tenha inibido a proliferação celular, nenhum deles induziu a apoptose. Quanto ao $\mathrm{NF}_{\kappa} \mathrm{B}$, apenas o tratamento com GGO na maior dose (16 mg/100 g de peso corpóreo) foi capaz de reduzir a quantidade de p65 no núcleo das células hepáticas (Espíndola et al., 2005). 
Não existem estudos prévios disponiveis na literatura comparando os efeitos de isoprenóides com a expressão e/ou ativação de NFkB em ratos submetidos à HP.

Assim, os resultados referentes à avaliação da apoptose (Figura 9) e à expressão de NFkB (Figura 11), sugerem que esse fator de transcrição não se encontra envolvido com a indução de apoptose observada nos animais tratados com o isoprenóide. 


\section{CONCLUSÕES}

- A administração de FR durante duas semanas consecutivas a ratos Wistar submetidos à hapatectomia parcial resultou em inibição da proliferação celular e indução da apoptose ;

- A inibição da proliferação celular por parte do FR pode estar relacionada com as alterações na expressão dos genes para HMG-CoA redutase, NFKB e ciclina D1;

- A indução da apoptose por parte do FR pode estar relacionada com as alterações na expressão do gene para HMG-CoA redutase. 


\section{REFERÊNCIAS}

AMERICAN CANCER SOCIETY. Cancer facts \& figures 2005. American Cancer Society, Atlanta, 2005. 64p.

ADJEI, A. A. Blocking oncogenic ras signaling for cancer therapy, J Natl Cancer Inst., v. 93, p. 1062-74, 2001.

AGARWAL, M. L.; TAYLOR, W. R;; CHERNOV, M. V.; CHERNOVA, O. B.; STARK, G. R. The p53 network. J. Biol. Chem., v. 273, p. 1-4, 1998.

AKCALI, K. C.; DALGIC, A.; UCAR, A.; HAJ, K. B.; GUVENC, D. Expression of bcl-2 gene family during resection induced liver regeneration: comparison between hepatectomized and sham groups. World J. Gastroenterol., v. 10, p. 279-83, 2004.

ALBERTS, D. S; GARCIA, D. L. An overview of clinical cancer prevention studies with emphasis on positive phase III studies. J. Nutr., v. 125, p. 692S7S, 1995.

AMES, B. N.; GOLD, L. S.; WILLETT, W. C. The causes and prevention of cancer. Proc. Natl. Acad.Sci USA, v. 92, p. 5258-65, 1995.

ANTHONY, M. L.; ZHAO, M.; BRINDLE, K. M. Inhibition of phosphatidylcholine biosynthesis following induction of apoptosis in HL-60 cells. J. Biol. Chem., v. 274 , p. $19686-92,1999$.

ARNOLD, J. T.; WILKINSON, B. P.; SHARMA, S.; STEELE, V. E. Evaluation of chemopreventive agents in different mechanistic classes using a rat tracheal epithelial cell culture transformation assay. Cancer Res., v. 55, p. 537-43, 1995.

ASHE, P. C.; BERRY, M. D. Apoptotic signaling cascades. Prog. Neuropsychopharmacol. Biol. Phychiatry, v. 27, p. 199-214, 2003.

ASSY, N.; MINUK, G. Y. Liver regeneration: methods for monitoring and their applications. J. Hepatol., v. 26, p. 945-52, 1997.

$\mathrm{BACH}, \mathrm{T}$. Some new aspects of isoprenoid biosynthesis in plant - a review. Lipids, v. 30, p. p. 191-202, 1995.

BALDWIN Jr, A. S. The NF-кB and $\mathrm{i}-\kappa \mathrm{B}$ proteins: new discoveries and insights. Annu. Rev. Immunol., v. 14, p. 649-81, 1996.

BANNASCH, P. Pre-neoplastic lesions as end points in carcinogenisis testing. I. Hepatic Preneoplasia. Carcinogenesis, v.7, p.689-695, 1986. 
BANNASCH, P., ZERBAN, H. Tumors of the liver. In: Pathology of Tumors in Laboratory Animals. V. S. TURUSOV, U. MOHR, eds. Lyon, IARC Scientific Publications no.99, v.1, p.199-240, 1990.

BEG, A. A.; RUBEN, S. M.; SCHEINMAN, R. I.; HASKILL, S.; ROSEN, C. A.; BALDWIM Jr, A. S. I kappa B interacts with the nuclear localization sequences of the subunits of NF-kappa B: a mechanism for cytoplasmic retention. Genes Dev., v. 6, p. 1899-913, 1992.

BEG, A. A.; FINCO, T. S.; NANTERMET, P. V.; BALDWIN, Jr, A. S. Tunour necrosis factor and interleukin-1 lead to the phosphorylation and loss of ikB: mechanism for NF-кB activation. Mol. Cell Biol., v. 13, p. 3301-3310, 1993.

BIRD, M. A.; BLACK, D. LANGE, P. A.; SAMSON, C. M.; HAYDEN, M.; BEHRNS, K. E. NFאB inhibition decrease hepatocyte proliferation but does not alter apoptosis in obstructive jaundice. J. Surg. Res., v. 114, p. 110-7, 2003.

BLANCO-COLIO, L. M.; VILLA, A.; ORTEGO, M.; HERNANDEZ-PRESA, M. A.; PASCUAL, A.; PLAZA, J. J.; EGIDO, J. 3-hydroxy-3-methyl-glutaryl coenzyme A reductase inhibitors, atorvastatins and simvastatins, induce apoptosis of vascular smooth muscle cells by downregulation of bcl-2 expression and rho A prenylation. Atherosclerosis, v. 161, p. 17-26, 2002.

BLANCO-COLIO, L. M.; JUSTO, P.; DAEHN, I.; LORZ, C.; ORTIZ, A.; EGIDO, J. Bcl-xL overexpression protects from apoptosis induced by HMG-CoA reductase inhibitors in tubular cells. Kidney Int., v. 64, p. 181-91, 2003.

BOONE, C. W; KELLOFF, G. L; MALONE, W. E. Identification of candidate cancer chemopreventive agents and their evaluation in animal models and human clinical trials: a review. Cancer Res., v. 50, p. 2-9, 1990.

BOYLAN, J. M.; GRUPPUSO, P. A. D-tyoe cyclins and G1 progression during liver development in rat liver. Biochem. Biphys. Res. Commun., v. 330, p. 722-30, 2005

BURKE, Y. D.; STARK, M. J.; ROACH, S. L.; SEN, S. E.; CROWELL, P. L. Inhibition of pancreatic cancer growth by the isoprenoids farnesol and geraniol. Lipids, v. 32, p. 151-6, 1997. 
BURKE, Y. D.; AYOUBI, A. S.; WERNER S. R.; McFARLAND, B. C.; HEILMAN, D. K.; RIGGERI, B. A.; CROWELL, P. L. Effects of the isoprenoids perillyl alcochol and farnesol on apoptosis biomarckres in pancreatic cancer chemoprevention. Anticancer Res., v. 22, p. 3127-34, 2002.

BURSCH, W., GRASL-KRAUPP, B., ELLINGER, A., TOROK, L., KIENZL, L. H., MULLAUER, L., SCHULTE-HERMANN, R. Active cell death: role in hepatocarcinogenesis and subtypes. Biochem. Cell. Biol., v.72, p.669-675, 1994.

CAPASSO, L., COSTANTINI, R. M. Paleopathology of human tumors. Med. Secoli, v. 6, p. 1-52, 1994.

CARTEE, L.; WANG, Z.; DECKER, R. H.; CHELLAPPAN, S. P.; FUSARO, G.; HIRSCH, K. G.; SANKALA, H. M.; DENT, P.; GRANT, S. The cyclindependent kinase inhibitor (CDKI) flavopiridol disrupts phorbol 12-myristate 13-acetate-induced differentiation and CDKI expression while enhancing apoptosis in human myeloid leukemia cells. Cancer Res., v. 61, p. 2583-91, 2001.

CASEY, P. J., SOLSKI, P. A., DER, C. J., BUSS, J. E. P21 ras is modified by a farnesyl isoprenoid. Proc. Natl. Acad. Sci, v. 86, p. 8323-8327, 1989.

CASE, G. L.; HE, L.; MO, H.; ELSON, C. E. Induction of geranyl pyrophosphate pyrophosphatase activity by cholesterol-suppressive isoprenois. Lipids, v. 30, p. 357-9, 1995.

CHAISSON, M. L.; BROOLING, J. T.; LADIGES, W.; TASI, S.; FAUSTO, N. Hepatocyte-specific inhibition of NF-kB leads to apoptosis after TNF treatment, but not after partial hepatectomy. J. Clin. Invest., v. 110, p. 193202, 2002.

CHEN, C.; EDELSTEIN, C.; GELINAS, C. The Rel/ NF-kappaB family directly activates expression of the apoptosis inhibitor $\mathrm{Bcl}-\mathrm{x}(\mathrm{L})$. Mol. Cell. Biol., v. 20, p. 2687-96, 2000.

CLARKE, P.; DeBIASI, L.; MEINTZER, S. M.; ROBINSON, B. A.; TYLER, K. L. Inhibition of NF-kB activity and cFLIP expression contribute to viral-induced apoptosis. Apoptosis, v. 10, p. 513-24, 2005 
CLEGG, R. J., MIDDLETON, B., BELL, G. D., WHITE, D. A. The mechanisms of cyclic monoterpene inhibition of 3-hydroxi-3methylglutaryl coenzyme A reductase in vivo in the rat. J. Biol. Chem., v. 257, p.2294-2299, 1982.

COLEMAN, P. S., LAVIETES, B. B. Membrane cholesterol, tumorigenesis and the biochemical phenotype of neoplasia. CRC Crit. Rev. Biochem., v. 11, p. 341-93, 1981.

COLUMBANO, A. Cell death: current difficulties in discriminating apoptosis from necrosis in the context of pathological processes in vivo. J. Cell. Biochem., v.58, p.181-190, 1995

CORRELL, C. C., NG, L., EDWARDS, P. A. Identification of farnesol as the nonsterol derivative of mevalonic acid required for the accelerated degradation of 3-hydroxi-3-methylglutaryl-coenzyme A reductase. J. Biol. Chem., v. 269, p. 17390-17393, 1994.

COURT, F. G.; WEMYSS-HOLDEN, A.; DENNISON, A. R.; MADDERN, G. J. The mystery of liver regeneration. Br. J. Surgery, v. 89, p. 1089-95, 2002.

CRESSMAN, D. E.; GREENBAUM, L. E.; HABER, B. A.; TAUB, R. Rapid activation of post-hepatectomy factor/nuclear factor kappa B in hepatocytes, a primary response in the regeneration liver. J. Biol. Chem., v. 269, p. 30429-35, 1994.

CRICK, D. C., ANDRES, D. A., WAECHTER, C. J. Farnesol is utilized for protein isoprenylation and the biosynthesis of cholesterol in mammalian cells. Biochem. Biophys. Res. Commun., v.211, p. 590-599, 1995.

CROWELL, P. L. Prevention and therapy of cancer by dietary monoterpenes. $J$. Nutr., v. 129, p. 775S-78S, 1999.

DAGLI, M. L. Z.; GUERRA, J. L.; SINHORINI, I. L.; WU, T. S.; RIZZI, M. B.; PENTEADO, M. V.; MORENO, F. S. Beta-carotene reduces the ductular (oval) cell reaction in the liver of Wistar rats submitted to the resistant hepatocyte modelo of hepatocarcinogenesis. Pathology, v. 30, p. 259-66, 1998.

DeANGELIS, R. A.; KOVALOVICH, K., CRESSMAN, D. E.; TAUB, R. Normal liver regeneration in p50/nuclear factor кB1 knockout mice. Hepatology, v. 33, p. 915-24, 2001. 
DeANGELIS, R. A.; MARKIEWSKI, M. M.; TAUB, R.; LAMBRIS, J. D. A high-fat diet impairs liver regeneration in C57BL/6 mice through overexpression of the NF-kappaB inhibitor, IkappaBalpha. Hepatology, v. 42, p. 1148-57, 2005.

Di GROCE, L.; BRUSCALUPI, G.; TRENTALANCE, A. Independent behavior of rat liver LDL receptor and HMGCoA reductase under estrogen treatment. Biochem. Biophys. Res. Commun., v. 224, p. 345-50, 1996.

DOLL, R; PETO, R. The causes of cancer: quantitative estimatives of avoidable risks of cancer in United States today. J. Natl Cancer Inst., v. 66, p. 1191308, 1981.

DRAGSTED, L. O.; STRUBE, M; LARSEN, J. C. cancer-protective factors in fruits and vegetables: biochemical and biological background. Pharmacol. Toxicol., v. 72, p. 388-93, 1993.

DUNCAN, R. E.; LAU, E.; EL-SOHEMY, A.; ARCHER, M. C. Geraniol, and beta-ionone inhibit proliferation, cell cycle progression, and cyclin-dependent kinase 2 activity in MCF-7 breast cancer cells independent of effects on HMG-CoA reductase activity. Biochem, Pharmacol., v. 68, p. 1739-47, 2004.

EDWARDS, P. A.; ERICSSON, J. Sterols and isoprenoids: signaling molecules derived from the cholesterol biosynthetic pathway. Annu. Rev. Biochem., v. 68, p. $157-85,1999$.

EL-BAYOUMY, K.; CHUNG, F. L.; RICHIE Jr, J.; REDDY, B. S.; COHEN, L.; WEISBURGER, J.; WYNDER, E. L. Dietary control of cancer. Proc. Soc. Exp. Biol. Med., v. 2, p. 211-23, 1997.

ELSON, C. E; YU, D. M. The chemoprevention of cancer by mevalonatederived constituents of fruits and vegetables. J. Nutr., v. 124, p. 607-14, 1994.

ELSON, C. E. Suppression of mevalonate pathway activities by dietary isoprenoids: protective roles in cancer and cardiovascular disease. J. Nutr., v. 125, p. 1666 S-72S, 1995

ELSON, C. E.; PEFFLEY, D. M.; HENTOSH, P.; MO, H. Isoprenoid-mediated inhibition of mevalonate synthesis: Potential application to cancer. Proc. Soc. Exp. Bio. Med, v. 221, p. 294-311, 1999. 
ESPÍNDOLA, R. M.; MAZZANTINI, R. P.; ONG, T. P.; De CONTI, A.; HEIDOR, R.; MORENO, F. S. Geranylgeraniol and beta-ionone inhibit hepatic preneoplastic lesions, cell proliferation, total plasma cholesterol and DNA damage during the initial phases of hepatocarcinogenesis, but only the former inhibits NF-kappaB activation. Carcinogenesis, v. 26, p. 1091-9, 2005.

ESTADOS UNIDOS DA AMÉRICA. World Cancer Research Fundation/American Institute for Cancer Research. "Patterns of cancer" In: Food, Nutrition and the Prevention of Cancer: a Global Perspective. P. 3552, 1997.

FAUSTO, N. Liver regeneration. J. Hepatol., v. 32, p. 19-31, 2000.

FARBER, E. Cell proliferation as a major risk factor for cancer: a concept of doubtful validity. Cancer Res., v. 55, p. 3759-3762, 1995.

FENECH, M. Biomarkers of genetic damage for cancer epidemiology. Toxicology, v. 181-182, p. 411-416, 2002.

FLACH, J., ANTONI, I., VILLEMIN, P., BENTZEN, C.L., NIESOR, E.J. The mevalonate/isoprenoid pathway inhibitor apomine (SR - $45023 \mathrm{~A})$ is antiproliferative and induces apoptosis similar to farnesol. Biochem. Biophys. Res. Commun., v.270, p.240-246, 2000.

FITZGERALD, M. J.; WEBBER, E. M.; DONOVAN, J. R.; FAUSTO, N. Rapid DNA biding by nuclear factor $\mathrm{\kappa B}$ in hepatocytes at the start of liver regeneration. Cell Growth Differ., v. 6, p. 417-27, 1995.

FONSECA, E. M.; CHAGAS, C. E. A.; MAZZANTINI, R. P.; HEIDOR, R.; ONG, T. P.; MORENO, F. S. All-trans and 9-cis retinoic acidis, retinol and betacarotene chemopreventive activities during the initial phases of hepatocarcinogenesis involve distinct actions on glutathione S-transferase positive preneoplastic lesions remodeling and DNA damage. Carcinogenesis, v. 26, p. 1940-6, 2005.

GARCIA-ROMAN, N.; ALVAREZ, A. M.; TORO, M. J.; MONTES, A.; LORENZO, M. J. Lovastatin induces apoptosis of spontaneously immortalized rat brain neuroblasts: involvement of nonsterol isoprenoid biosynthesis inhibition. Mol. Cell. Neurosci., v. 17, p. 329-41, 2001. 
GESCHER, A.; PASTORINO, U.; PLUMMER, S. M.; MANSON, M. M. Suppression of tumour development by substances derived from the diet mechanisms and clinical implications, Br. J. Clin. Pharmacol., v. 45, p. 1-12, 1998.

GHOSH, S.; MAY, M. J.; KOPP, E. B. NF-kappa B and rel proteins: evolutionarity conserved mediators of immune responses. Annu. Rev. Immunol., v. 16, p. 225-60, 1998.

GOLDSTEIN, J. L., BROWN, M. S. Regulation of the mevalonate pathway. Nature, v.343, p.425-430, 1990.

GOULD, M. N. Prevention and therapy of mammary cancer by monoterpenes. J. Cell. Biochem., v. 22, p. 139S-44S, 1995.

GRASL-KRAUPP, B., BURSCH, W., RUTTKAY-NEDECKY, B., WAGNER, A., LAUER, B., SHULTE-HERRMANN, R. Food restriction eliminates preneoplastic cells through apoptosis and antagonizes carcinogenesis in rat liver. Proc. Natl. Acad. Sci. USA, v. 91, p. 9995-9999, 1994

GREAVES, M. Cancer causation: the darwian downside of past success. Lancet Oncol., v. 3, p. 244-251, 2002.

GREEN, D. R.; REED, J. C. Mitochondria and apoptosis. Science, v. 281, p. 1309-12, 1998.

GREENWALD, P. Cancer chemoprevention. BMJ, v. 324, p. 714-718, 2002.

HABENICHT, A. J.; GLOMSET, J. A.; ROSS, R. Relation of cholesterol and mevalonic acid to the cell cycle in smooth muscle and swiss 3 T3 cells stimulated to divide by platelet-derived growth factor. J. Biol. Chem., v. 255, p. $5134-40,1980$.

HAKIM, I. A., HARTZ, V., GRAVER, E., WHITACRE, R., ALBERTS, D. Development of a questionnaire and a database for assessing dietary $\mathrm{d}$ limonene intake. Public Health Nutr., v.5, p. 939-945, 2002.

HANAHAN, D., WEINBERG, R. A. The hallmarks of cancer. Cell, v. 100, p. 57$70,2000$.

HANCOCK, J. F., MAGEE, A. I., CHILDS, J. E., MARSHALL, C. J. All ras proteins are isoprenylated but only some are palmitoylated. Cell, v. 577, p. 1167-1177, 1989. 
HE, L., MO, H., HADISUSILO, S., QURESHI, A. A., ELSON C. E. Isoprenoids supress the growth of murine B16 melanomas in vitro and in vivo. J. Nutr., v. 127, p. $668-674,1997$

HENGARTNER, M. O. The biochemistry of apoptosis. Nature, v. 407, p. 770-6, 2000.

HENNEKES, H., NIGGS, E. A. The role of isoprenylation in membrane attachment of nuclear lamins: A single point mutation prevents proteolytic cleavage of the lamin A percursor and confers membrane binding properties. J. Cell. Sci., v.107, p. 1019-1029, 1994.

HONG, W. K.; SPORN, M. B. Recent advances in chemoprevention of cancer. Science, v. 278. p. 1073-7, 1997.

HSU, Y. L.; KUO, Y. C.; KUO, P. L.; NG, L. T.; KUO, Y. H.; LIN, C. C. Apoptosic effects of extract from Antrodia camphorate fruiting bodies in humam hepatocelular carcinoma cell lines. Cancer Lett., v. 221, p. 77-89, 2005

HUI, A. M.; MAKUUCHI, M. Molecular basis of multistep hepatocarcinogenesis: genetic and epigenetic events. Scand. J.Gastroenterol., v. 34, p. 737-42, 1999.

HUI, T. T.; MIZUGUCHI, T.; SUGIYAMA, N.; AVITAL, I.; ROZGA, J.; DEMETRIOUS, A. A. Immediate early genes and $\mathrm{p} 21$ regulation in liver of rats with acute hepatic faileture. Am. J. Surg., v. 183, p. 457-63, 2002.

IARC. World Cancer report. B.W STEWART, P. KLEIHUES, eds. IARC Press/Oxford University Press, 2003.

IIMURO, Y.; NISHIURA, T.; HELLERBRAND, C.; BEHRNS, K. E.; SCHOONHOVEN, R.; GRISHAM, J. W.; BRENNER, D. A. NFkB prevents apoptosis and liver dysfunction during liver regeneration. J. Clin. Invest., v. 101, p. 802-811, 1998.

IWAO, K; TSUKAMOTO, I. Quercetin inhibited DNA synthesis and induced apoptosis associated with increase in c-fos mRNA level and the upregulation of $\mathrm{p} 21^{\text {WAF/CIP1 }}$ mRNA and protein expression during liver regeneration after partial hepatectomy. Biochem. Biophys. Acta. V. 1427, p. 112-120, 1999.

JEMAL, A., MURRAY, T., SAMUELS, A., GHAFOOR, A., WARD, E., THUN, M. J. Cancer statistics, 2003. CA Cancer J. Clin., v. 53, p. 5-26, 2003. 
JESUS, R. P.; WAITZBERG, D. L.; CAMPOS, F. G. Regeneração hepática: papel dos fatores de crescimento e nutrientes. Rev. Ass. Méd. Brasil., v. 46, p. 242-54, 2000.

JOICE, D.; ALBANESE, C.; STEER, J.; FU, M.; BOUZAHZAH, B.; PESTELL, R.

G. NF-kB and cell-cycle regulation: the cyclin connection. Cytokine Growth Factor Rev., v. 12, p. 73-90, 2001.

JONES, S. M.; KAZLAUSKAS, A. Growth factor-dependent signaling and cell cycle progression. FEBS Letters, v. 490, p. 110-6, 2001.

JOO, M.; KANG, Y. K.; KIM, M. R.; LEE, H. K.; JANG, J. J. Cyclin D1 overexpression in hepatocelluar carcinoma. Liver, v. 21, p. 89-95, 2001

KAMATA, H.; HONDA, S, I.; MAEDA, S.; CHANG, L.; HIRATA, H.; KARIN, M.

Reative oxygen species promote TNFa-induced death and sustained JNK activation by inhibiting MAP kinase phosphatases. Cell, v. 120, p. 649-661, 2005

KASTAN, M. B.; ONYEKWERE, O.; SIDRANSKY, D.; VOGELSTEIN, B.; CRAIG, R. W. Participation of p53 protein in the cellular response to DNA damage. Cancer Res., v. 51, p. 6304-11, 1991.

KATO, A.; OTA, S.; BAMBA, H.; WONG, R. M.; OHMURA, E.; IMAI, Y.; MATSUZAKI, F. Regulation of cyclin D-dependent kinase activity in rat liver regeneration. Biochem. Biophys. Res. Commun., v. 245, p. 70-4,1998.

KAUFMANN, W. K.; PAULES, R. S. DNA damage and cell cycle checkpoints. FASEB J., v. 10, p. 238-47, 1996.

KLAUNIG, J. E., KAMENDULIS, L. M., XU, Y. Epigenetic mechanisms of chemical carcinogenesis. Hum. Exp. Toxicol., v. 19, p. 543-555, 2000.

KLIGERMAN, J. Estimativas sobre a incidência e mortalidade por câncer no Brasil - 2002. Rev. Bra. Cancerologia, v. 48, p. 175-179, 2002.

KOBAYASHI, K.; TSUKAMOTO, I. Prolonged jun N-terminal kinase (JNK) activation and the upregulation of $\mathrm{p} 53$ and $\mathrm{p} 21^{\text {WAF/CIP1 }}$ preceded apoptosis in hepatocytes after partial hepatectomy and cysplatin. Biochem. Biophys. Acta, v. 1537, p. 79-88, 2001.

KOMATSU, M.; TSUKAMOTO, I.; Effetc of folic acid on thymicylate synthase and thymidine kinase in regeneration rat liver after partial hepatectomy. Biochem. Biophys, Acta, v. 1379, p. 289-96, 1998. 
KONIARIS, L. G.; MCKILLOP, I. H.; SCHWARTZ, S. I.; ZIMMERS, T. A. Liver regeneration. J. Am. Coll. Surg., v. 197, p. 634-59, 2003

KOOLMAN, J., ROHM, K. Isoprenoids. In: Color Atlas of Biochemistry. J. KOOLMAN, K. ROHM, eds, Thieme, Stuttgart, p. 50-51, 1996.

KREN, B. T.; TREMBLEY, J. H.; KRAJEWSKI, S.; BEHRENS, T. W.; REED, J. C.; STEER, C. J.; Modulation of apoptosis-associated genes $b c /-2, b c l-x$, and bax during liver regeneration. Cell Growth Differ., v. 7, p. 1633-42, 1996

LAGACE, T. A.; MILLER, J. R.; RIDGWAY, N. D.; Caspase processing and nuclear export of CTP:phosphocholine cyticyltransferase $\alpha$ during farnesolinduced apoptosis. Mol Cell. Biol., v. 22, p. 4851-62, 2002.

LIU, R. H. Potential synergy of phytochemicals in cancer prevention: mechanism of action. J. Nutr., v. 134, p. 3479S-85S, 2004.

LOEB, L. A., LOEB, K. R., ANDERSON, J. P. Multiple mutations and cancer. Proc. Nat. Acad. Sci, v. 100, p. 776-781, 2003.

LOTA, M-L., DE ROCCA SERRA, D., TOMI, F. L., JACQUEMOND, C., CASANOVA, J. Volatile components of peel and leaf oils of lemon and lime species. J. Agric. Food Chem., v. 50, p. 796-805, 2002.

LUEDDE, T.; ASSMUS, U.; WUSTEFELD, T.; VILSENDORF, A. M.; ROSKAMS, T.; SCHIMIDT-SUPPRIAN, M.; RAJEWSKY, K.; BRENNES, D. A.; MANNS, M. P.; PASPARAKIS, M.; TRAUTWEIN, C. Deletion of ikk2 in hepatocytes does not sensitize these cells to TNF-induced apoptosis but protects from ischemia/reperfusion injury. J. Clin. Invest., v. 115, p. 849-59, 2005.

MARSHALL, C. J. Protein prenylation: A mediator of protein-protein interactions. Science, v. 259, p.1865-1866, 1993

MARTINEZ-BOTAS, J.; FERRUELO, A. J.; SUÁREZ, Y., FERNANDEZ, C. GOMES-CORONADO, D.; LASUNCION, M. A. Dose-dependent effect of lovastatin on cell cycle progression Distinct requirement of cholesterol and non-sterol mevalonate derivatives. Biochim. Biophys. Acta, v. 1532, p. $185-$ 94, 2001.

MAYER, R. J., ADAMS, J. L., BOSSARD, M. J., BERKHOUT, T. A. Effects of a novel lanosterol 14 alfa-demethylase inhibitor on the regulation of 3-hidroxy3-methylglutaryl-coenzyme A reductase in HepG2 cells. J. Biol. Chem., v. 266, p. 20070-20078, 1991. 
MAK, T. W.; YEH, W. C. Signaling for survival and apoptosis in immune system Arthritis Res., v. 4, p. S243-52, 2002.

MAZZANTINI, R. P; ONG, T. P.; HEIDOR, R.; CHAGAS, C. E. A.; MORENO, F. S. Minerais e câncer. In: COZZOLINO, S. M. F. Biodisponibilidade de Nutrientes. $1^{\circ}$ edição. Barueri: Manole, 2005. cap. 37, p. 736-87.

MEIGS, T. E., SIMONI, R. D. Farnesol as a regulator of HMG-CoA reductase degradation: Characterization and role of farnesyl pyrophosphatase. Arch. Biochem. Biophys., v. 345, p. 1-9, 1997.

MCANALLY, J. A., JUNG, M., MO, H. Farnesyl-O-acetylhydroquinone and geranyl-O-acetylhydroquinone suppress the proliferation of murine B16 melanoma cells, human prostate and colon adenocarcinoma cells, human lung carcinoma cells, and human leukemia cells. Cancer Lett., v. 202, p. 181-192,. 2003.

MINISTÉRIO DA SAÚDE. INSTITUTO NACIONAL DO CÂNCER - INCA. Estimativa 2006: Incidência de cancer no Brasil. INCA, Rio de Janeiro, $2005,98 p$

MIQUEL, K.; PRADINES, A.; TERCE, F.; SELME, S.; FAVRE, G.; Competitive inhibition of choline phosphotransferase by geranylgeraniol and farnesol inhibits phosphophstidylcholine synthesis and indices apoptosis in human lung adenocarcinomas A549 cells. J. Biol. Chem., v. 273, p. 26179-86, 1998

MO, H., ELSON, C. E. Apoptosis and cell-cycle arrest in human and murine tumor cells are initiated by isoprenoids. J. Nutr., v. 129, p. 804-813, 1999.

MO, H., TATMAN, D., JUNG, M., ELSON, C. E. Farnesyl anthranilate suppresses the growth, in vitro and in vivo, of murine B16 melanomas. Cancer Lett., v. 157, p. 145-53, 2000

MO, H.; ELSON, C. E. Studies of the isoprenoid-mediated inhibition oh mevalonate synthesis applied to cancer chemotherapy and chemoprevention. Exp. Biol. Med., v. 229, p. 567-85, 2004.

MORENO, F. S.; RIZZI, M. B.; DAGLI, M. L. Z. PENTEADO, M. V. Inhibitory effects of beta-carotene on preneoplastic lesions induced in Wistar rats by the resistant hepatocyte model. Carcinogenesis, v. 12, p. 1871-22, 1991. 
MORENO, F. S.; WU, T. S.; PENTEADO, M. V. C.; RIZZI, M. B. S. L.; JORDÃO Jr, A. A.; ALMEIDA-MURADIAN, L. B.; DAGLI, M. L. Z. A comparison of $\beta$ carotene and vitamin A effects on a hepatocarcinogenesis model. Int. J. Vitam. Nutr Res., v. 65, p. 87-94, 1995a.

MORENO, F. S.; ROSSIELO, M. R.; MANJESHWAR, S.; NATH, R.; RAO, P. M.; RAJALAKSHMI, S.; SARMA, D. S. R. Effect of beta-carotene on the expression of 3-hydroxy-3-methylglutaryl coenzime A reductase in rat liver. Cancer Lett., v. 96, p. 201-8, 1995 b.

MORI, H., SUGIE, S., YOSHIMI, N., HARA, A., TANAKA, T. Control of cell proliferation in cancer prevention. Mutat. Res., v. 428, p. 291-298, 1999.

MORI, H., NIWA, K., ZHENG, Q., YAMADA, Y., SAKATA, K., YOSHIMI, N. Cell proliferation in cancer chemoprevention, effects of preventive agents on estrogen-related endometrial carcinogenesis model and on an in vitro model in human colorectal cells. Mutat. Res., v. 480-481, p. 201-207, 2001.

MORSE, M. A.; STONER, G. D. Cancer chemoprevention: principles and prospects. Carcinogenesis, v. 14, p. 17-28, 2001.

MULCAHY, L. S; SMITH, M. R.; STACEY, D. W. Requirement for ras protooncogene function during serum-stimulated growth of NIH 3T3 cells. Nature, v. 313, p. 241-3, 1985.

NAVES, M. M.; SILVEIRA, E. R.; DAGLI, M. L. Z.; MORENO, F. S. Effetcs of beta-carotene and vitamin A on oval cell proliferation and conexin 43 expression during hepatic differentiation in the rat. J. Nutr. Biochem., v. 12, p. $685-92,2001$.

ONG, T. P; HEIDOR, R.; De CONTI, A.; DAGLI, M. L. Z; MORENO, F. S. Farneso, and geraniol chemipreventive activities during the initial phases of hepatocarcinogenesis involve similar actions on cell proliferation and DNA damage, but dinstict actions on apoptosis, plasma cholesterol and HMGCoA reductase. Carcinogenesis, Aceito para publicação em 6 de dezembro de 2005.

ORTEGA, S.; MALUMBRES, M.; BARBACID, M.; Cyclin D-dependent kinases, INK4 inhibitors and cancer. Biochem. Biphys. Acta, v. 1602, p. 73-87, 2002. PARK, C.; LEE, I.; KANG, W. K. Lovatatin-induced E2F-1 modulation and its effect on prostate cancer cell death. Carcinogenesis, v. 22, p. 1727-31, 2001. 
PARKER, R. A., PEARCE, B. C., CLARK, R. W., GORDAN, D. A., WRIGHT, J. J. K. Tocotrienols regulate cholesterol production in mammalian cells by post-transcriptional suppression of 3-hydroxi-3-methylglutaryl-coenzyme A reductase. J. Biol. Chem., v. 268, p. 11230-11238, 1993.

PEZZUTO, J. M. Plant-derived anticancer agents. Biochem. Pharmacol., v. 53, p. 121-33, 1997.

PHILCHENKOV, A. Caspases: potential targets for regulatin cell death. J. Cell. Mol. Med., v. 8, p. 432-44, 2004.

PIBIRI, M.; LEDDA-COLUMBANO, G. M.; COSSU, C.; SIMBULA, G.; MENEGAZZI, M.; SHINIZUKA, H.; COLUMBANO, A. Cyclin D1 is na early target in hepatocyte proliferation induced by thyroid hormone (T3). FASEB J., v. 15, p. 1006.-13, 2001.

PITOT, H. C. Pathway of progression in hepatocarcinogenesis. Lancet, v. 358, p. 859-860, 2001

PITOT, H. C., DRAGAN, Y. P. Facts and teories concerning the mecanisms of carcinogenisis. FASEB J., v.5, p.2280-2286, 1991.

PLUMPE, J.; MALEK, N. P.; BOCK, C. T.; RAKEMANN, T.; MANNS, M. P.; TRAUTWEIN, C. NF-kB determines between apoptosis and proliferation in hepatocytes during liver regeneration. Am J. Physiol Gastrointest. Liver Physiol., v. 278, p. G173-G183, 2000.

QUESNEY-HUNEEUS, V.; WILEY, M. H.; SIPERSTEIN, M. D. Essential role for mevalonate synthesis in DNA replication. Proc. Natl. Acad. Sci., v. 76, p. 5056-60, 1979.

QURESHI, A. A., MANGELS, W. R., DIN, Z. Z., ELSON, C. E. Inhibition of mevalonate biosynthesis by the monoterpene d-limonene. J. Agric. Food. Chem., v. 36, p. 1220-1224, 1998.

RAO, K. N. Regulatory aspects of cholesterol metabolism in cells with different degrees of replication. Toxicol. Pathol., v. 14, p. 430-437, 1986

RAO, C. V., NEWMARK, H. L., REDDY, B. S. Chemopreventive effect of farnesol and lanosterol on colon carcinogenesis. Cancer Detect. Prev., v. 26, p.419-425, 2002. 
RENINGER, J. A.; GOLDSWORTHY, T. L.; BABISH, J. G. Time course comparison of cell-cycle protein expression following partial hepatectomy and WY14,643-induced hepatic cell proliferation in F344 rats. Carcimogenesis, v. 18, p. 935-41, 1997.

RETIEF, F. P., CILLIERS L. Tumours and cancers in Graeco-Roman times. S. Afr. Med. J., v. 91, p. 344-348, 2001.

RIOJA, A.; PEZZEY, A. R.; MARSON, C. M.; SHAUN, N.; THOMAS, B. Preferential induction of apoptosis of leukaemic cells by farnesol. FEBS Letters, v. 467, p. 291-5, 2000.

RISS, T.L. Apoptosis as a biomarker in chemoprevention trials. Urology, v. 57, p. 141-142, 2001.

RIZZI, M. B; DAGLI, M. L. Z; JORDÃO Jr, A. A.; PENTEADO, M. V. MORENO, F. S. Beta-carotene inhibits persistent and stimulates remodeling gamma GT-positive preneoplastic lesions during early promotion of hepatocarcinogenesis. Int. J. Vitam. Nutr. Res., v. 67, p. 41522, 1997.

ROTHSCHILD, B. M., WITZKE, B. J., HERSHKOVITZ, I. Metatastic cancer in the Jurassic. Lancet, v. 354, p. 398, 1999.

RUST, C., GORES, J. G. Apoptosis and liver disease. Am. J. Med., v. 108, p. 567-574, 2000.

SACCHETTINI, J. C.; POUTER, C. D. Creating isoprenoid diversity. Science, v. 277, p. $1788-89,1997$.

SAMBROOK, J.; RUSSEL, D. L. Extraction, purification and analysis of mRNA from eukaryotic cells. In: SAMBROOK, J.; RUSSEL, D. W. Molecular cloning: a laboratory manual. Nova Yorque: Cold Spring Harbour Lab. Press, v. 1, 2001, p. 7.4-7.88, 2001.

SARASTE, A., PULKKI, K. Morphological and biochemical hallmarks of apoptosis. Cardiovascular Res., v. 45, p. 528-537, 2000

SCHRUM, L. W.; BLACK, D.; IIMURO, Y., RIPPE, R. A.; BRENNER, D. A.; BEHRNS, K. E. C-Jun does not mediate hepatocyte apoptosis following NFkappaB inhibition and partial hepatectomy. J Surg. Res., v. 88, p. 142-9, 2000. 
SERRANO, M.; GOMEZ-LAHOZ, E.; De PINHO, R. A.; BEACH, D.; BAR-SAGI, D. Inhibition of ras-induced proliferation and cellular transformation by p16INK4. Science, v. 267, p. 249-52, 1995.

SEVER, N., SONG, B-L, YABE, D., GOLDSTEIN, J. L., BROWN, M. S., et al. Insig-dependent ubiquitination and degradation of mammalian 3-hydroxy-3methylglutaryl CoA reductase stimulated by sterols and geranylgeraniol. $J$. Biol. Chem., v. 278, p. 52479-52490, 2003.

SGONC, R., GRUBER, J. Apoptosis detection: an overview. Exp. Gerentology, v. 33, p. $525-533,1998$.

SHARMA, S.; STUTZMAN, J. D.; KELLOFF, G. L; STEELE, V.E. Screening of potential chemopreventive agents using biochemical markers of carcinogenesis, Cancer Res., v. 54, p. 5848-55, 1994.

SHEARER, A. G.; HAMPTON, R. Y. Lipid-mediated, reversible misfolding of sterol-sensing domais protein. EMBO J., v. 24, p. 149-59, 2005.

SHELLMAN, Y. G.; BIBBLE, D.; MILLER, L.; GENDALL, J.; VANBUSKIRK, K, KELLY, D.; NORRIS, D. A; DELLAVALLE, R. P. Lovastatin-induced apoptosis in human melanoma cell lines. Melanoma Res., v. 15, p. 83-9, 2005.

SHOFF, S. M., GRUMMER, M., YATVIN. M. B., ELSON, C. E. Concentrationdependent increase of murine P388 and B16 population doubling time by the acyclic monoterpene geraniol. Cancer Res., v.51, p. 37-42, 1991.

SICHIERI, R., EVERHART, J. E., MENDONÇA, J. A. S. Diet and mortality from common cancers in Brazil: an ecological study. Cad. Saúde Públ., v. 12, p. 53-59, 1996.

SMUCKLER, E. A. Chemicals, cancer and cancer biology. West J. Med., v.139, p.55-74, 1983.

SPORN M. B.; DUNLOP, N. M.; NEWTON, D. L.; SMITH, J. M. Prevention of chemical carcinogenesis by vitamin $\mathrm{A}$ and it is synthetic analogs (retinoids). Fed. Proc., v. 35, p. 1332-8, 1976

SPORN, M. B; SUH, N. - Chemoprevention: an essential approach to controlling cancer. Nature Rev., 2: 537-743, 2002. 
STACEY, D.; KAZLAUSKAS, A. Regulation of the ras signaling by the cell cycle. Curr Opin Genet Dev., v. 12, p. 44-6, 2002STANLEY, L. A. Molecular aspects of chemical carcinogenesis: the roles of oncogenes and tumour suppressor genes. Toxicology, v. 96, p. 173-94, 1995.

STEELE, V. E. Current mechanistic approaches to the chemoprevention of cancer. J. Biochem. Mol. Biol., v. 36, p. 78-81, 2003.

STEMER, B. A.; BIANCHINI, G. M.; KORTH, K. L. Regulation of HMG-CoA reductase activity in plants. J. Lipid. Res., v. 35, p. 1133-40, 1994.

STINCHCOMBE, S., BUCHMANN, A., BOCK, K. W., SCHWARZ, M. Inhibition of apoptosis during 2,3,7,8-tetrachlorodibenzo-p-dioxin-mediated tumour promotion in rat liver. Carcinogenesis, v. 16, p. 1271-1275, 1995.

STONER, G. D.; MORSE, M. A.; KELlOFF, G. D. Perspective in cancer chemoprevention. Environ. Health Perspect., v. 105, p. 945

STRYER, L. Biosynthesis of membrane lipids and steroid hormones. In: Biochemistry. L. STRYER, ed., W. H. Freeman and Co., NY, p.547-74, 1988.

SUÁREZ, Y.; FERNÁNDEZ, C.; LEDO, B.; MARTÍN, M.; GÓMEZ-CORONADO, D.; LASUNCIÓN, M. A. Sterol stringency of proliferation and cleel cycle progression in human cells. Biochem. Biophys. Acta., v. 1734, p. 203-13, 2005.

SUBBARAYAPPA, B. V. The roots of ancient medicine: an historical outline. J. Biosci., v. 26, p. 135-144, 2001.

SUN, S. Y. Apoptosis induction by chemopreventive agents. Drug News Perspect., v. 14, p. 75-80, 2001.

TAKUWA, N; TAKUWA, Y. Ras activity late in G1 phase required for p27kip1 downregulation, passage through the restriction point, and entry into $\mathrm{S}$ phase in growth factor-stimilated NHI 3 T3 fibroblasts. Mol. Cell. Biol., v. 17, p. 5348-58, 1997.

TAKUWA, N.; TAKUWA, Y. Regulation of cell cycle molecules by the ras effector system. Mol. Cel. Endocrinol., v. 177, p. 25-33, 2001.

TANNENBAUM, A. Relationship of body weight to cancer incidence. Arch. Path., v. 30, p. 509-17, 1940.

TANNENBAUM, A. The genesis and growth of tumours. II. Effect of caloric rescriction per se. Cancer Res., v. 2, p. 460-7, 1942a. 
TANNENBAUM A. The genesis and growth of tumours. III. The effect of high-fat diet. Cancer Res., v. 2, p. 468-74, 1942b.

TSUCHIYA, R., FUJISAWA, N. Historical survey of carcinoma of the pancreas. J. Hepatobiliary Pancreat. Surg., v. 6, p. 165-170, 1999.

TATMAN, D., MO, H. Volatile isoprenoid constituents of fruits, vegetables and herbs cumulatively suppress the proliferation of murine b16 melanoma and human HL-60 leukemia cells. Cancer Lett., v.175, p. 129-139, 2002.

TAO, L., KRAMER, P. M., WANG, W., YANG, S., LUBET, R. A., STEELE, V. E., PEREIRA, M. A. Altered expression of c-myc, p16 and p27 in rat colon tumors and its reversal by short-term treatment with chemopreventive agents. Carcinogenesis, v. 23, p.1447-1454, 2002

TAUB, R. Liver regeneration: from myth to mechanism. Nat. Rev. Mol. Cell Biol., v. 5, 836-47, 2004.

TOLEDO, L. P.; ONG, T. P.; PINHO, A. L.; JORDÃO Jr, A. A.; VANNUCCHI, H.; MORENO, F. S. Inhibitory effects of lutein and lycopene on placental glutathione S-transferase-positive preneoplastic lesions and DNA strand breakage induced in Wistar rats by the resistant hepatocyte model of hepatocarcinogenesis. Nutr. Cancer, v. 47, p. 62-9, 2003.

TOMATIS, L. Cell proliferation and carcinogenesis: a brief history and current view based on na IARC workshop report. International Agency for Research on Cancer. Environ. Health. Perspec., v.101. p. 149-151, 1993.

TZUNG, S. P; FAUSTO, N.; HOCKENBERY, D. M. Expression of bcl-2 family during liver regeneration and identification of $b c l-x$ as a delayed early response gene. Am. J. Pathol., v. 150, p. 1985-95, 1997.

UEDA, N., SHAH, S. Apoptosis. J. Lab. Clin. Med., v.124, p.169-77, 1994.

VAIDYA, S.; BOSTEDOR, R.; KURTZ, M. M.; BERGSTROM, J. D.; BANSAL, V. S. Massive production of farnesol-derived dicarboxylic acids in mice treated with the sqalene synthetase inhibtor zaragozic acid A. Arch. Biochem. Biophys., v. 355, p. 84-92, 1998

VOZIYAN, P. A.; HAUG, J. S.; MELNYKOVYCH, G. Machanism of farnesol cytotoxicity: further evidence for the role of PKC-dependent signal transduction in farnesol-induced apoptotic cell death. Biochem. Biophys. Res. Commun., v. 212, p. 479-86, 1995. 
.WATTERBERG, L. W. Chemoprevention of cancer. Cancer Res., v. 45, p. 1-8. 1985.

WEISBURGER, J. H. Antimutagenesis and anticarcinogenesis, from the past to the future. Mutat. Res., v. 23-35, p. 480-481, 2001.

WESTFALL, D., ABOUSHADI, N., SHACKELFORD, J. E., KRISANS, S. K. Metabolismo fo farnesol: phosphorylation of farnesol by rat liver microsomal and peroxisomal fractions. Biochem. Biophys. Res. Commun., v. 230, p. 562-568, 1997

WYNDER, E; GORI, G. Contribution of the environment to cancer incidence: na epidemiological exercise. J. Natl. Cancer Inst., v. 58, p. 825-32, 1977.

WRIGHT, M. M.; HENNEBERRY, A., L.; LAGACE, T. A.; RIDGWAY, N. D.; McMASTER, C. R. Uncoupling farnesol-induced apoptosis from its inhibition of phosphatidylcholine synthesis. J. Biol. Chem., v. 27, p. 25254-61, 2001.

WÜNSCH FILHO, V., MONCAU, J. E. Mortalidade por câncer no Brasil: 19801995: padrões regionais e tendências temporais. Rev. Assoc. Med. Bras., v. 48, p. $227-250,2002$.

YOUNG, R. C. Cancer statistics, 2002: progress or cause for concern? CA Cancer J., v. 512, p. 6-7, 2002.

YOUNG, M. R., YANG, H-S., COLBURN, N. H. Promising molecular targets for cancer prevention: AP-1, NF-kB and Pdcd4. Trends in Molec. Med., v. 9., p. 36-41, 2003.

YU, S. G., ABUIRMEILEH, N. M., QURESHI, A. A., ELSON, C. E. Dietary $\beta-$ ionone suppresses hepatic 3-hidroxy-3-methylglutaryl coenzyme A reductase activity. J. Agric. Food. Chem., v. 42, p. 1493-1496, 1994.

YU, S. G., HILDEBRANDT, L. A., ELSON, C. E. Geraniol, an inhibitor of mevalonate biosynthesis, supress the growth of hepatomas e melanomas transplanted to rats and mice. J. Nutr., v. 125, p. 2763-2767, 1995.

ZHANG, Y. J.; JIANG, W.; CHEN, C. J.; LEE, C. S.; KAHN, S. M.; SANTELLA, R. M.; WEINSTEIN, I. B. Amplification and overexpression of cyclin D1 in human hepatocellular carcinoma. Biochem. Biphys. Res. Commun., v. 196, p. 1010-16, 1993. 


\section{SUMARY}

CHAGAS, C. E. A. Farnesol inhibits cell proliferation and induces apoptosis in liver after partial hepatectomy in Wistar rats. FCF-USP, São Paulo, 2006. Master degree dissertation.

Epidemiological data have shown that nutrients and others bioactive compounds in food have chemopreventive activities against cancer. Among these compounds, isoprenoids are suggested either as a chemopreventive or chemotherapy agents. However, despite these evidences, studies focused on the isoprenoids activities on cell proliferation and apoptosis in vivo are rare. Thus, the effect of the 15-carbon isoprenoid farnesol on liver regeneration after partial hepatectomy was evaluated. Wistar rats were treated for two consecutive weeks with farnesol (FR group, $25 \mathrm{mg} / 100 \mathrm{~g}$ body weight) or corn oil (OM group, control, 0,25 mL/100 g body weight) and killed at different time points after partial hepatectomy (HP; $0 \mathrm{~h}, 30 \mathrm{~min}, 2 \mathrm{~h}, 4 \mathrm{~h}, 8 \mathrm{~h}, 12 \mathrm{~h}, 18 \mathrm{~h}$ and $24 \mathrm{~h}$ ). Still, hepatic cell proliferation (PCNA lebeled nuclei), apoptosis (quantification of apoptotic bodies), p65 and cyclin D1 protein expression (western blot) and HMG-CoA reductase mRNA expression (dot blot) were also evaluated. Comparing to OM group, farnesol treatment significantly inhibited $(p<0,05)$ hepatic cell proliferation $24 \mathrm{~h}$ after HP. Regarding apoptosis, also compared to controls, farnesol treated rats presented more $(p<0,05)$ apoptotic bodies at 30 min. Besides, there were a suggestion of a higher number of apoptotic bodies 2 and 12 hours after HP in FR group comparing to OM group. According to western blot analysis, comparing to controls, this 15-carbon isoprenoid reduced $40 \%$ and 50\% p65 and cyclin D1 hepatic protein expression, $30 \mathrm{~min}$ and $24 \mathrm{~h}$ after partial hepatectomy, respectively, although the differences did not also reach the statistical significance. Furthermore, farnesol treated rats had higher $(\mathrm{p}<0,05)$ HMG-CoA reductase mRNA levels than controls $2 \mathrm{~h}$ and $12 \mathrm{~h}$ after the surgery. Theses data suggest that the alterations on p65, cyclin D1 and HMGCoA reductase gene expression observed in FR group might be associated with the inhibition of cell proliferation and the induction of apoptosis by farnesol.

Key words: Partial hepatectomy, farnesol, cell proliferation, apoptosis, NF-кB, cyclin D1, HMG-CoA reductase. 